\title{
Supporting biodiversity in European vineyards: \\ Possibilities for winegrowers and economic implications
}

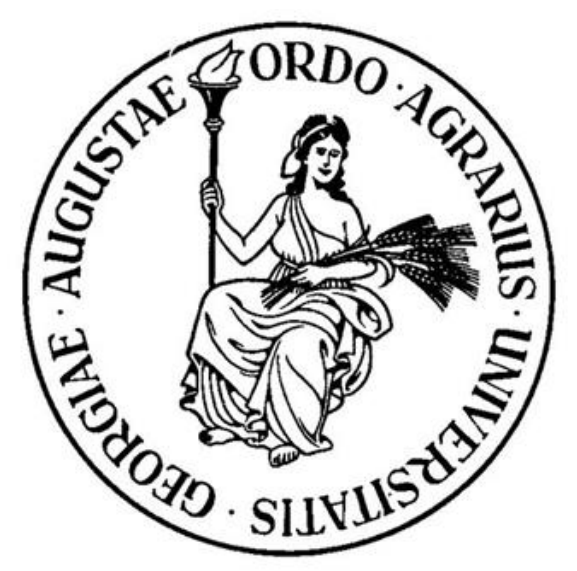

\author{
Dissertation \\ to attain the doctoral degree (Dr. sc. Agr.) \\ of the Faculty of Agricultural Sciences, \\ Georg-August-Universität Göttingen
}

Submitted by

Rebekka Schütte

Born on the $12^{\text {th }}$ of August 1990 in Bremerhaven

Göttingen, May 2019 
D 7

1. Referee: Prof. Dr. Stephan von Cramon-Taubadel

2. Referee: Prof. Dr. Tobias Plieninger

Date of oral examination: 28 June 2019 
One never notices what has been done; one can only see what remains to be done.

(Marie Curie) 


\section{Acknowledgment - Danksagung}

In vier Jahren wissenschaftlicher Arbeit verliert man manchmal den Überblick darüber, was bereits geschafft wurde und ich bin außerordentlich froh, dass die Arbeit schließlich zu einem Ende gekommen ist. Nun bleibt nichts mehr, außer Danke zu sagen.

Zunächst möchte ich mich bei meinem Doktorvater Prof. Dr. Stephan von CramonTaubadel für die Betreuung und die freundliche Unterstützung zum rechten Moment bedanken. Zudem bedanke ich mich recht herzlich bei Prof. Dr. Tobias Plieninger für die Übernahme des Zweitgutachtens.

Besonders möchte ich mich bei meinem Drittprüfer Dr. Holger Bergmann für die Möglichkeit, in dem interdisziplinären Projekt VineDivers mitzuarbeiten, bedanken.

Dieses Projekt hat mir viele neue Einblicke in einen für mich bis dahin unbekannten Bereich der Landwirtschaft geboten und war eine großartige Reise mit einigen Herausforderungen. Außerdem bedanke ich mich für die kontinuierliche Motivation und die vielen hilfreichen Anmerkungen während meiner Promotion. Dieser Dank gilt insbesondere auch Dr. Elke Plaas. Ich weiß nicht, ob ich es ohne ihre Ratschläge, speziell in Hinblick auf die Methodik, Denkanstöße, Korrekturlesungen und die unzähligen motivierenden Worte geschafft hätte. Vielen Dank für alles.

Unglaublich dankbar bin ich meiner Familie. Durch sie habe ich all die Unterstützung erfahren, die man sich nur wünschen kann. Mein großer Bruder, ich kann gar nicht in Worte fassen, wie wichtig du für mich bist. Ihr habt immer an mich geglaubt und mich zu der gemacht, die ich heute bin. Clemens, danke, dass du an meiner Seite bist und immer zu mir stehst. Und natürlich für die besonders liebevolle Versorgung in der stressigsten Phase vor der Abgabe.

Die Jahre in Göttingen vergingen wie im Flug und es haben mich so viele auf diesem Weg begleitet und mir die Promotionszeit nicht langweilig werden lassen. Ich kann nicht alle hier nennen, aber besonders dankbar bin ich meinen guten Freundinnen, allen voran Sara, Meli und Jane, die immer ein offenes Ohr für mich hatten.

Danke an alle, die diese Zeit bereichert haben. 


\section{Content}

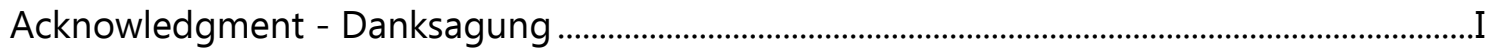

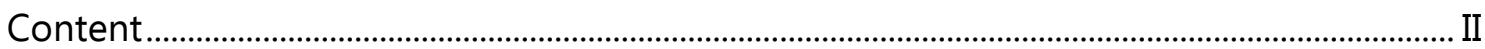

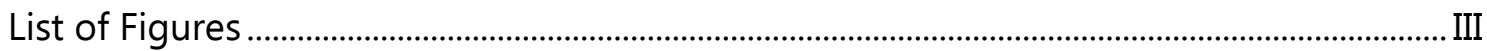

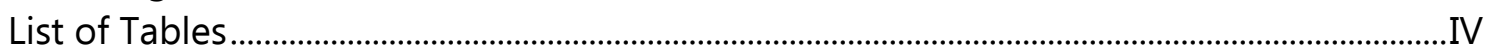

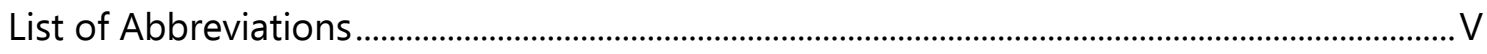

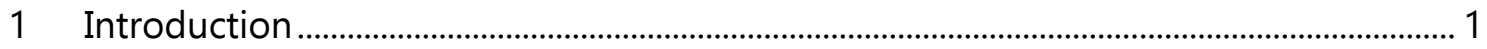

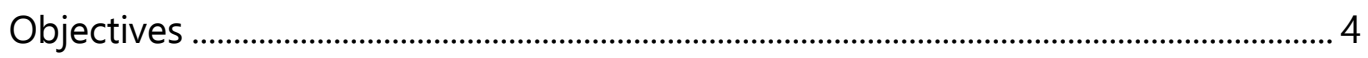

2 Insights into the vinicultural sector: Market and Politics................................................... 6

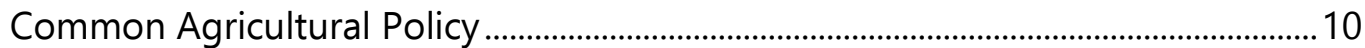

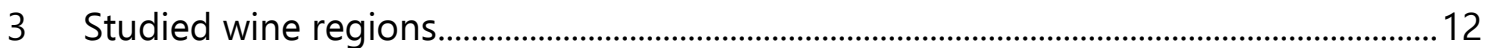

4 The Attitudes of French and Spanish Winegrowers towards the use of Cover Crops

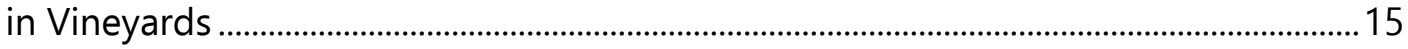

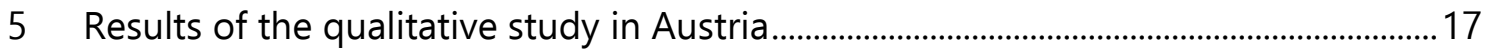

6 Profitability of erosion control with cover crops in European vineyards under

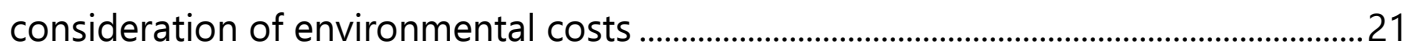

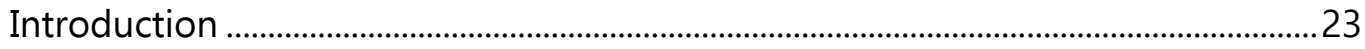

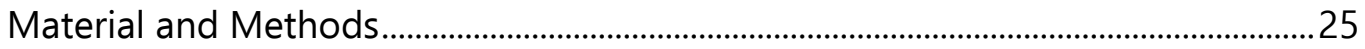

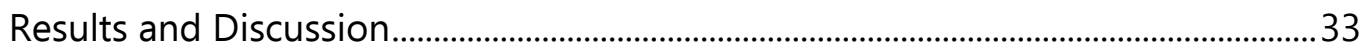

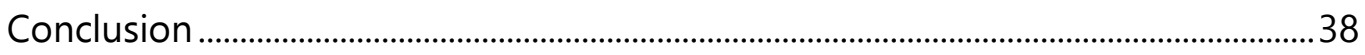

7 How cover crops and soil biota could improve wine prices. A competitive analysis

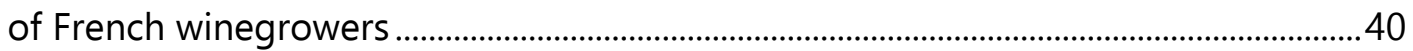

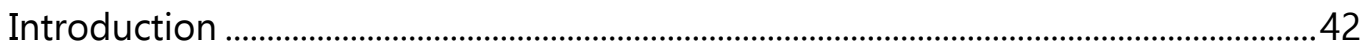

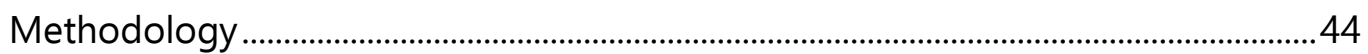

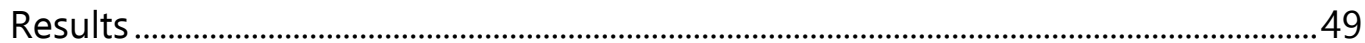

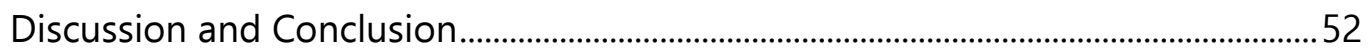

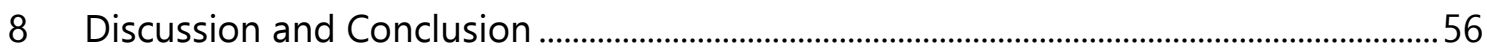

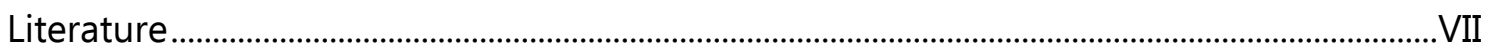

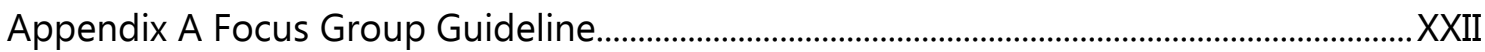

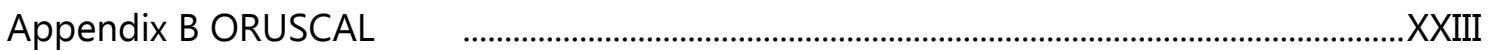

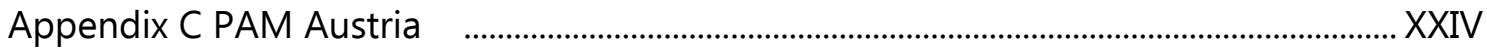

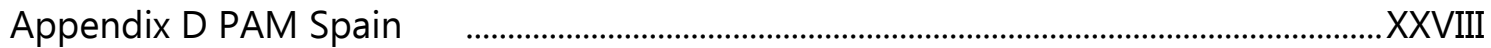

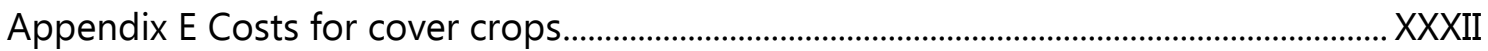

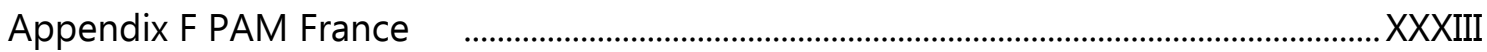

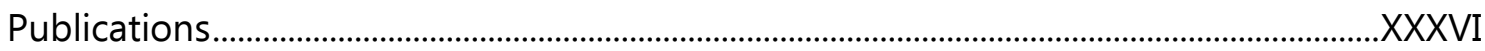

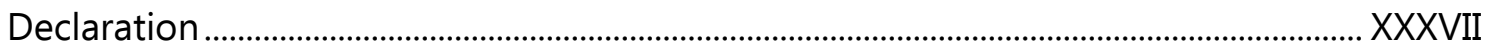




\section{List of Figures}

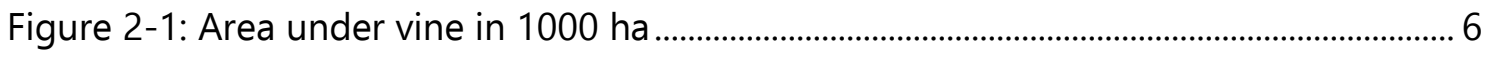

Figure 2-2: Share of world wine production volume .............................................................. 8

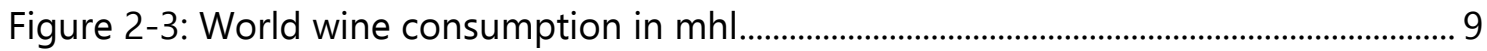

Figure 2-4: Per capita consumption in litres............................................................................ 9

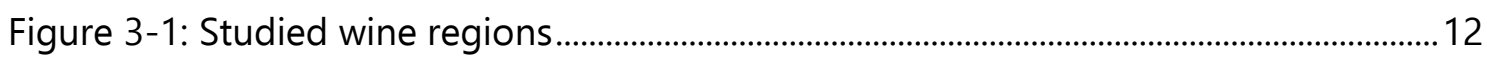

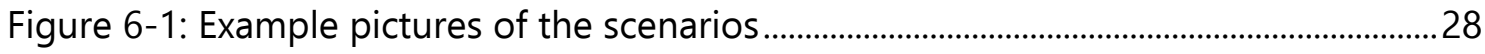

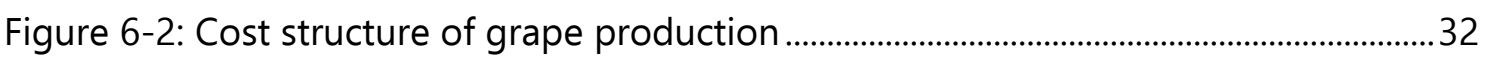

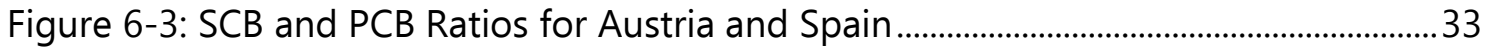

Figure 7-1: The wine growing area DGO 'Coteaux du Layon' in the Loire Valley ..............45

Figure 7-2: Abundance of soil biota under bare soil and CC management..........................50

Figure Appendix B-1: General construction of ORUSCAL .................................................XXIII 


\section{List of Tables}

Table 2-1: Distribution of vineyards in EU-28 and wine production ........................................ 7

Table 3-1: Summary Research regions ..................................................................................

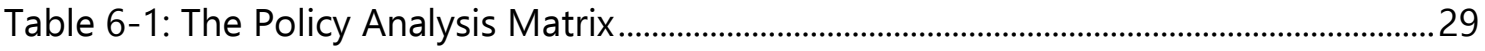

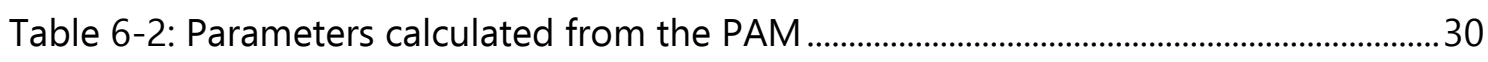

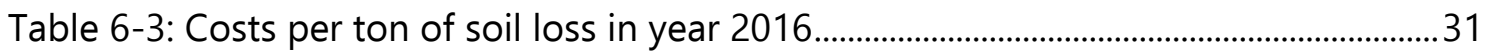

Table 6-4: Changes in Erosion Costs compared to CT (Montilla-Moriles) ...............................34

Table 6-5: Changes in Erosion Costs compared to CT (Carnuntum) ........................................35

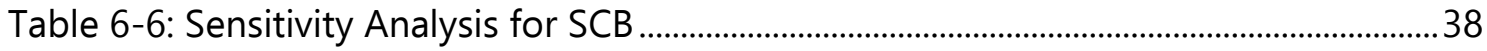

Table 7-1: The Policy Analysis Matrix.........................................................................................48

Table 7-2: Additional WTP for environmental friendly produced wine ..................................51

Table 7-3: Coefficients from the PAM scenarios in 'Coteaux du Layon' .................................51

Table Appendix C-1: Basic Budget Austria......................................................................XXIV

Table Appendix C-2: Basic PAM and Parameters Austria .................................................. XXIV

Table Appendix C-3: CT (Case A) Budget Austria ..............................................................XXV

Table Appendix C-4: CT (Case A) PAM and Parameters Austria ...........................................XXV

Table Appendix C-5: TCC (Case A) Budget Austria ...........................................................XXVI

Table Appendix C-6: TCC (Case A) PAM and Parameters Austria ...................................... XXVI

Table Appendix C-7: PCC (Case A) Budget Austria .............................................................XXVII

Table Appendix C-8: PCC (Case A) PAM and Parameters Austria .....................................XXVII

Table Appendix D-1: Basic Budget Spain .........................................................................XXVIII

Table Appendix D-2: Basic PAM and Parameters Spain .................................................XXVIII

Table Appendix D-3: CT (Case A) Budget Spain ..............................................................XXIX

Table Appendix D-4: CT (Case A) PAM and Parameters Spain......................................... XXIX

Table Appendix D-5: TCC (Case A) Budget Spain......................................................................XXX

Table Appendix D-6: TCC (Case A) PAM and Parameters Spain.........................................XXX

Table Appendix D-7: PCC (Case A) Budget Spain ..............................................................XXX

Table Appendix D-8: PCC (Case A) PAM and Parameters Spain........................................ XXXI

Table Appendix E-1: Costs for Cover Crops in Montilla-Moriles ........................................XXXII

Table Appendix E-2: Costs for Cover Crops in Carnuntum ....................................................XXXII

Table Appendix F-1: Basic Budget France .........................................................................XXXIII

Table Appendix F-2: Basic PAM and Parameters France .....................................................XXXIII

Table Appendix F-5: CC Budget France........................................................................XXXIV

Table Appendix F-6: CC PAM and Parameters France......................................................XXXIV

Table Appendix F-7: CC and Marketing Budget France..................................................XXXV

Table Appendix F-8: CC and Marketing PAM and Parameters France............................XXXV 


\section{List of Abbreviations}

AEMs

AMA

AT

CAP

CC

CES

CGE

$\mathrm{CMO}$

CT

DG Agri

DG Ipol

DGO

DRC

EPC

ES

ESP

EU

EW

FR

GA

$\mathrm{Ha}$

$\mathrm{HI}$

HVE

Mha

Mhl

MS

$\mathrm{Mt}$

NPCI

NPCO

OECD

OIV

OM

ORUSCAL

PAM

PCB

PCC

PCR

PDO
Agri-environment measures

AgrarMarkt Austria

Austria

Common agricultural policy

Cover crops

Cultural ecosystem services

Computable general equilibrium

Common market organisation

Conventional tillage

Directorate-General for Agriculture and Rural Development

Directorate-General for Internal Policies

Designation of geographical origin (France)

Domestic resource cost

Effective protection coefficient

Ecosystem services

Spain

European Union

Earthworms

France

Gastropods

Hectare

Hectolitres

Haute Valeur Environnementale

Million hectares

Million hectolitres

Member states

Million tons

Nominal protection coefficient on inputs

Nominal protection coefficient on outputs

Organization for Economic Cooperation and Development International Organisation of Vine and Wine

Organic matter

Orchard RUSle CALibration

Policy analysis matrix

Private cost benefit

Permanent cover crops

Private cost ratio

Protected designation of origin 
PGI

$\mathrm{PL}$

PPP

$S C B$

$\mathrm{Sm}$

TCC

USA

WTP
Protected geographical indication

Plants

Plant protection products

Social cost benefit

soil moisture

Temporary cover crops

United States of America

Willingness to pay 


\section{Introduction}

Grapevine is one of the oldest cultivated plants of humanity and provides the basis for a variety of wines since thousands of years. Nowadays, drinking wine is an established habit in many cultures and societies. Thus, a huge industry and global market for wine has developed. The European Union (EU) has always been a world leader in wine production.

Although countries all over the world have entered the market, the EU still accounts for over $60 \%$ of the worldwide production, with Spain, France and Italy remaining top producers (EUROPEAN COMMISSION, 2017). In the EU, $5 \%$ of all agricultural output derives from wine production (DG AGRI, 2015A: 9) and 7.8\% (10 billion $€$ ) of all agricultural exports are wine (EUROPEAN COMMISSION, 2015B: 4).

Besides the economic scope of the sector, vineyards have a relevant influence on the environment and ecosystem services (ES). When thinking of vineyards, one can imagine beautiful green, well-arranged landscapes; however, conventional viniculture is not as eco-friendly as it may seem. The environment in wine areas is not only characterised by a monocultural landscape but is also affected by significant applications of plant protection products (PPP). Only $8 \%$ of the European agricultural area is covered with vineyards, yet more than $40 \%$ of all PPP (fungicides, herbicides and insecticides) are used there. This disparity is even more obvious for fungicides of which $70 \%$ are used to protect vines (PнYтOWELT GMBH, 2003: 26), due to high pressure caused by powdery and downy mildew.

While insecticides play a minor role and can successfully be replaced by pheromones (LUCCHI ET AL., 2018; OSTERATH, 2014), herbicides with the active substance glyphosate are the second biggest group of PPP (EUROSTAT, 2007: 15). Herbicides and tillage are used to keep vineyards free of competing vegetation which is especially important in semi-arid regions where vines need every bit of water and nutrients. Glyphosate is not uncritical and is suspected of being carcinogenic (GUYTON ET AL., 2015). Moreover, GAUPP-BERGHAUSEN ET AL. (2015) proves that glyphosate has a harmful influence on earthworms. The intensive use of pesticides and bare soil management has further negative environmental side effects, such as water contamination and soil degradation (LESCOT ET AL., 2014: 284). 
In addition to management effects, vineyards are often located on slopes and in Mediterranean climatic conditions. Thus, vineyards belong to the most degraded soils in Europe and show a higher average soil loss rate than other agricultural lands (PANAGOS ET AL., 2015: 442; PROSDOCIMI ET AL., 2016).

However, according to BOLLER ET AL. (1997: 299), “Vineyards have a special capacity to establish and maintain a high degree of biodiversity". Today, biodiversity is a frequently used term and describes the variety of species, genes and ecosystems. It is widely accepted that there is a need to protect this variety as it has many values for mankind (MACE, 2014: 45). As a consequence, the EU implemented a biodiversity strategy, which aims at "reversing biodiversity loss and speeding up the EU's transition towards a resource efficient and green economy" (EUROPEAN COMMISSION, 2011). This includes a focus on sustainable agriculture, and therefore sustainable viniculture, which is determined by soil condition.

The strong connection between soil quality and food provision is recognized in the Sustainable Development Goals of the United Nations, which postulates the implementation of resilient agriculture practices to improve soil quality (UN GENERAL ASSEMBLY, 2015). This is critical as many ES depend on healthy soils and various soil organisms (PLAAS ET AL., 2019).

A step towards a biodiversity friendly wine production is the supply of ES through the use of cover crops (CC) which especially affects belowground biodiversity. CC can be either temporary or permanently used. And while spontaneous vegetation is an option, special seed mixtures are also available. Still, both species and management have to be chosen with caution and should be adapted to the regional conditions (PARDINI ET AL., 2002). According to WINTER ET AL. (2018), greened inter-rows have a positive effect on ecosystems and enhance biodiversity and ES by $20 \%$.

Vegetation cover also has a positive effect on soil erosion mitigation and soil properties, such as water infiltration, aggregate stability and organic carbon storage, as shown in various studies (BAGAGIOLO ET AL., 2018; GÓMEZ ET AL., 2011; GUZMÁN ET AL., 2019; MCGOURTY \& REGANOLD, 2005; RUÍZ-COLMENERO ET AL., 2013).

Furthermore, pollinators benefit from a complex landscape and the provision of floral resources through extensive inter-row management (KRATSCHMER ET AL., 2019). 
A complex landscape also contributes to cultural ecosystem services (CES) of vineyards. CES are relevant for locals (WINKLER \& NICHOLAS, 2016) and tourists (HERVÉ ET AL., 2018) and can influence management choices of landowners (PLIENINGER ET AL., 2015). Moreover, CC can have functional benefits for winegrowers. They can control pests (BERNDT ET AL., 2006) and improve the practicability of inter-rows for machinery (MERCENARO ET AL., 2014; PARDINI ET AL., 2002). In some cases they can help to control the vigour of vines (MERCENARO ET AL., 2014). This is beneficial for producing high quality wine, which often requires a yield reduction in favour of higher quality grapes.

These positive effects are, to some extent, already known since decades (HOLZGANG ET AL., 1996) but CC are still not the predominant management in European vineyards. Mostly due to economic restrictions, winegrowers hesitate to change their management (MARQUES ET AL., 2015; SCHÜTTE \& BERGMANN, 2019). Cultivating CC is work intensive and labour is a limiting factor, especially on family-operated businesses. Time and money need to be invested in new knowledge and machinery. But the economic situation of small-scale farmers often does not leave scope for investments. In addition, there is a perceived risk of yield losses in rain-fed vineyards under water scarce conditions if CC are not managed properly.

Nevertheless, for direct sellers, greened inter-rows can have additional benefits as a marketing instrument. With the growing awareness for sustainability and environment protection, consumers show a higher willingness to pay (WTP) for sustainably produced wine (SCHÄUfELE \& HAMM, 2017), which could be an opportunity for European winegrowers. 


\section{Objectives}

Based on the depicted importance of viniculture for environment and economy, it is crucial to gain insights into the trade-offs between an eco-friendly production system and the competitiveness of winegrowers. Yet, research covering the economic effects of a biodiversity friendly vineyard management is rare. In this context, competitiveness is defined as the "ability of farms to remain in the sector". It requires that farms are profitable even after deducting all costs, especially family labour (EUROPEAN COMMISSION \& DG AGRI, 2012: 6).

Equally important is a better understanding of the underlying incentives for management decisions of winegrowers, if new policies are to be adopted. This work contributes to fill this research gap and broadens the knowledge about the difficulties of adapting new management methods.

Based on the presented research, it is presumed that less intensive management systems will lead to higher biodiversity. Extensive management, in contrast to intensive management, includes the reduction of pesticides as well as the use of CC. The studies were carried out in three European wine regions, specifically Carnuntum in Austria (AT), Coteaux du Layon in France (FR) and Montilla-Moriles in Spain (ESP).

The overriding goal of this thesis is to support the construction of policies which respect the interests of winegrowers, society and environment alike, bearing in mind that "every policy decision is not only a trade-off decision between ES, but also between who benefits from the ES" (WINKLER \& NICHOLAS, 2016: 96).

Chapter 2 gives more background information about the world wine market, the position of participating European winegrowers and the common agricultural policy (CAP). The research regions are presented in detail in Chapter 3.

Initially, the attitudes of winegrowers towards CC and their perception of the general situation were evaluated during focus group discussions and additional interviews. In Chapter 4, the qualitative study "The Attitudes of French and Spanish Winegrowers towards the use of Cover Crops in Vineyards" presents results from these focus groups. In addition Chapter 5 presents the results of the qualitative study in Austria. These results lay the foundation for competitiveness analysis of different management scenarios. 
The study "Profitability of erosion control with cover crops in European vineyards under consideration of environmental costs" is the content of Chapter 6. Here, based on soil erosion rates, on- and off-side erosion costs are included in a competitive analysis of different soil management scenarios in Carnuntum (AT) and MontillaMoriles (ESP). The economic implications of management changes are modelled with the Policy Analysis Matrix (PAM) and are subject to a sensitivity analysis.

The study "How cover crops and soil biota could improve wine prices. A competitive analysis of French winegrowers" in Chapter 7 provides valuable insights into the competitiveness of winegrowers in Coteaux du Layon (FR). Vegetation cover, and accordingly a reduced application of herbicides, benefits not only earthworms but also entails a higher WTP. Higher output prices for sustainably produced wine are assumed and are shown to cover the additional costs for this management.

A comprehensive discussion and concluding remarks are given in Chapter 8 . 


\section{Insights into the vinicultural sector: Market and Politics}

Over the last decades the global wine market was subject to constant change. The supremacy of Europe's wine production was exposed to ambitious competitors from the New World as well as China. Figure 2-1 shows that China increased its vine area while in Europe it was reduced. Vines, for the production of wine and table grapes, grow on around 7.5 million hectares (mha) worldwide. In 2017, a total of 73.3 million ton (mt) grapes were produced (OIV, 2018A: 4, 8).

\section{Figure 2-1: Area under vine in 1000 ha}

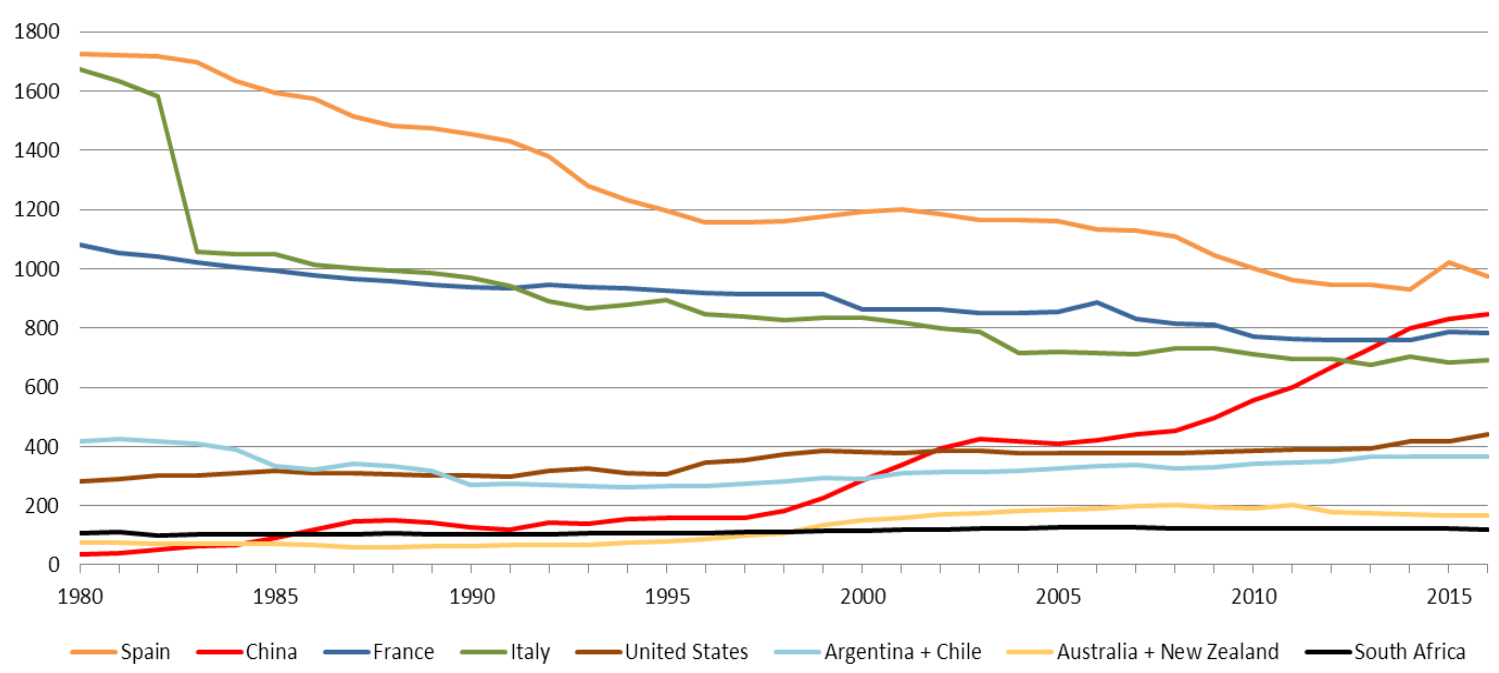

Source: Own figure based on (ANDERSON \& PINILLA, 2017)

The global wine production fluctuates around 270 million hectolitre (mhl) and reflects not only the change in vineyard area but also the weather dependency, which particularly hit European winegrowers hard in 2017. The early bloom came upon unusual late frosts and led to harvest reductions of up to $20 \%$ in some member states (MS) and an overall decrease of $14.6 \%$ in the EU (OIV, 2018B: 6).

Nearly three quarters of all European vineyards can be found in Spain, France and Italy collectively, as can be seen in Table 2-1. In the EU, the production is based mainly on small-scale holdings, while vineyards in competing countries tend to be larger (MENGHI ET AL., 2011: 218 F). 
In Spain and Italy the holdings are on average only about 2 ha in size. In comparison, French vineyards are on an average five times as large.

Table 2-1: Distribution of vineyards in EU-28 and wine production

\begin{tabular}{lrrrrr} 
& Share of vine area & mhl & ha & vineyard holdings & ha/holding \\
\hline EU 28 & $100 \%$ & 165.1 & 3230241 & 2484963 & 1.3 \\
\hline Spain & $29.1 \%$ & 40.0 & 941154 & 517615 & 1.82 \\
France & $24.9 \%$ & 45.4 & 802896 & 76453 & 10.5 \\
Italy & $20.1 \%$ & 50.9 & 650690 & 381141 & 1.71 \\
\hline Portugal & $6.1 \%$ & 6.0 & 198586 & 212128 & 0.94 \\
Romania & $5.7 \%$ & 3.3 & 183717 & 854766 & 0.21 \\
Germany & $3.2 \%$ & 9.0 & 102581 & 43389 & 2.36 \\
\hline Austria & $1.4 \%$ & 2.0 & 45574 & 14133 & 3.22 \\
Others & $9.4 \%$ & 8.5 & 305043 & 385338 & 0.79
\end{tabular}

Source: Own table based on (EUROSTAT, 2017: 11, 13; OIV, 2018B: 7). Data for 2015; Mhl for 2016

Many of the producer countries also belong to the main consumers; therefore, less than half of the production $(107.9 \mathrm{mhl})$ is traded on the world market with a total value of 30.4 billion $€$.

However, the traded volume is constantly growing since the 2000's. Spain is the main exporter in terms of volume $(22.1 \mathrm{mhl})$ but markets mainly inexpensive bulk wine which leads to an average price of $1.27 € / 1$. By contrast, France exports less in terms of volume $(15.4 \mathrm{mhl})$ but more superior-quality bottled wine with a total value of 9 billion $€$ and an average price of $5.84 € / l$. Together with Italy, these countries account for nearly $55 \%$ of the total market.

The top five importers of wine are Germany, United Kingdom, USA, France, and China. While Germany and France import larger shares of bulk wine, the other importing countries prefer bottled wine (OIV, 2018B: $10 \mathrm{FF})$.

Although China mainly produces table grapes and its wine production started not until the late 1970 's, it rapidly gained significance and now reaches a $4 \%$ share of the world production. Another player on the market is the United States of America (USA), who grew to be the fourth biggest wine producer (23.3 mhl), right behind the European competitors. Australia, Argentina, China and South Africa all produce more than $10 \mathrm{mhl}$. 
Consequently, the share of the core wine production countries (France, Italy and Spain) of the world production decreased from $80 \%$ in 1920 to $50 \%$ in 2016. as displayed in Figure 2-2 (ANDERSON ET AL., 2017: 182 F; OIV, 2018B: 7).

\section{Figure 2-2: Share of world wine production volume}

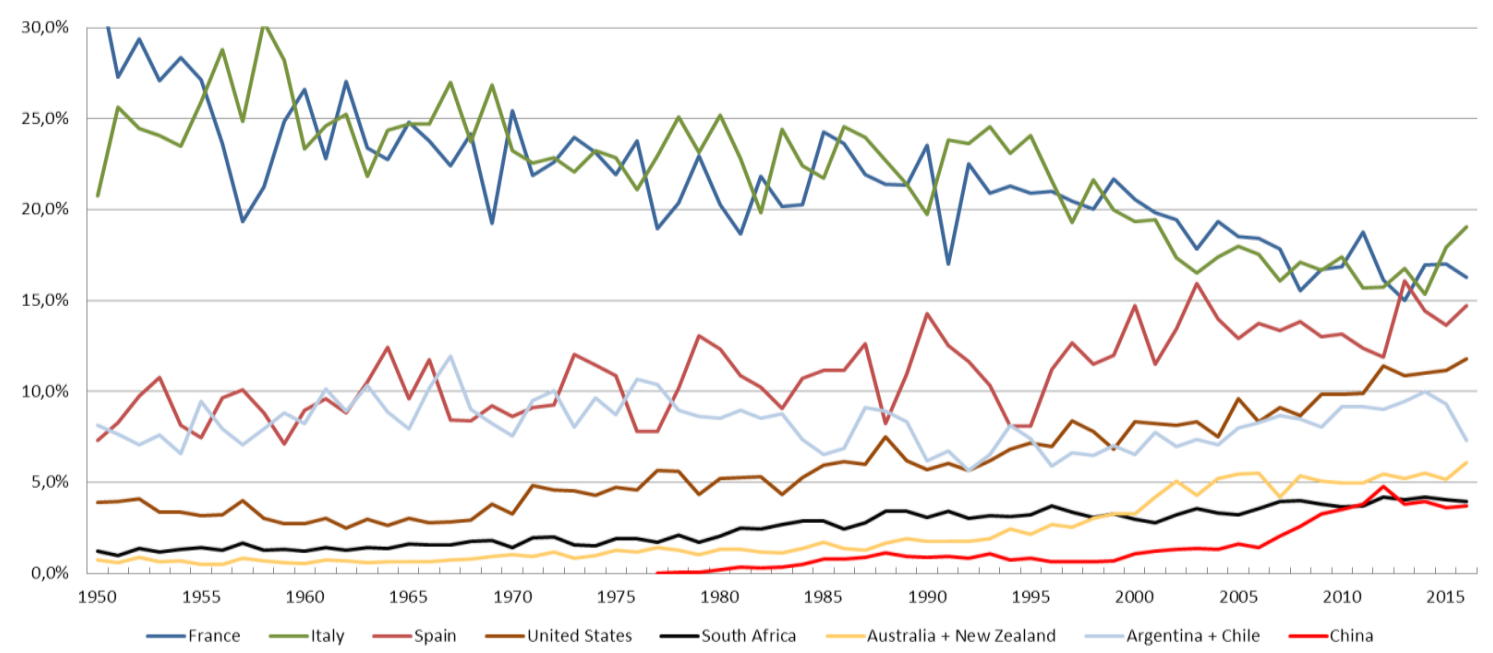

Source: Own figure based on (ANDERSON \& PINILLA, 2017)

There is not only a shift of wine production from Europe to America and Asia, but an increasing internationalization can also be observed on the consumer side (DPA, 2015; HOFFMANN, 2015: 62).

In Southern Europe, wine is losing its characteristic as a staple food and older generations who consumed wine on a daily basis are shrinking. For younger generations, wine is more of a semi-luxury beverage and is consumed rather occasionally. In addition, health concerns are decreasing the overall alcohol consumption even further (DPA/LRS, 2016; WENGE, 2017).

Therefore, European winegrowers are more dependent on acquiring new sales markets. These have been established in Asia and America and the consumption in these continents is still rising (DG AGRI, 2015B: 7). Not surprisingly, Chinas domestic demand for wine is the main reason for the global trade growth (OIV, 2018B: 14).

As Figure 2-3 presents, total consumption decreased since the 1980 's but the rising consumption outside of Europe is, to some extent, compensating for the decline in domestic consumption in the core production countries. 
Figure 2-3: World wine consumption in $\mathrm{mhl}$

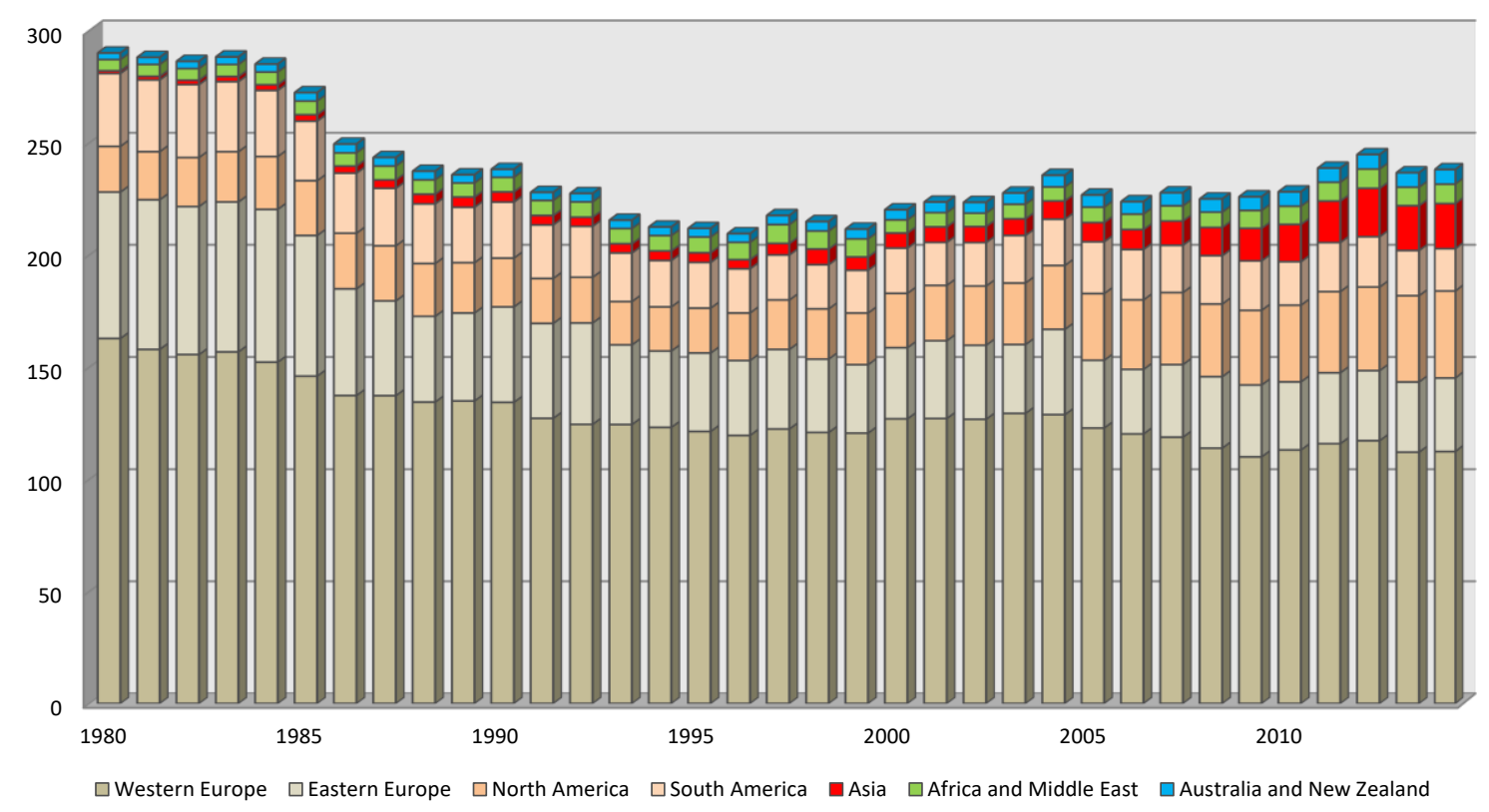

Source: Own figure based on (ANDERSON \& PINILLA, 2017)

As a result, the per capita consumption is gradually aligning, as illustrated in Figure 2-4. Interestingly enough, the per capita consumption is relatively stable in Austria and remains even higher than in Spain. This also applies for Germany. It also demonstrates that there is still scope for growth, especially considering the emergent middle class and purchasing power in Asia (KHARAS, 2017).

\section{Figure 2-4: Per capita consumption in litres}

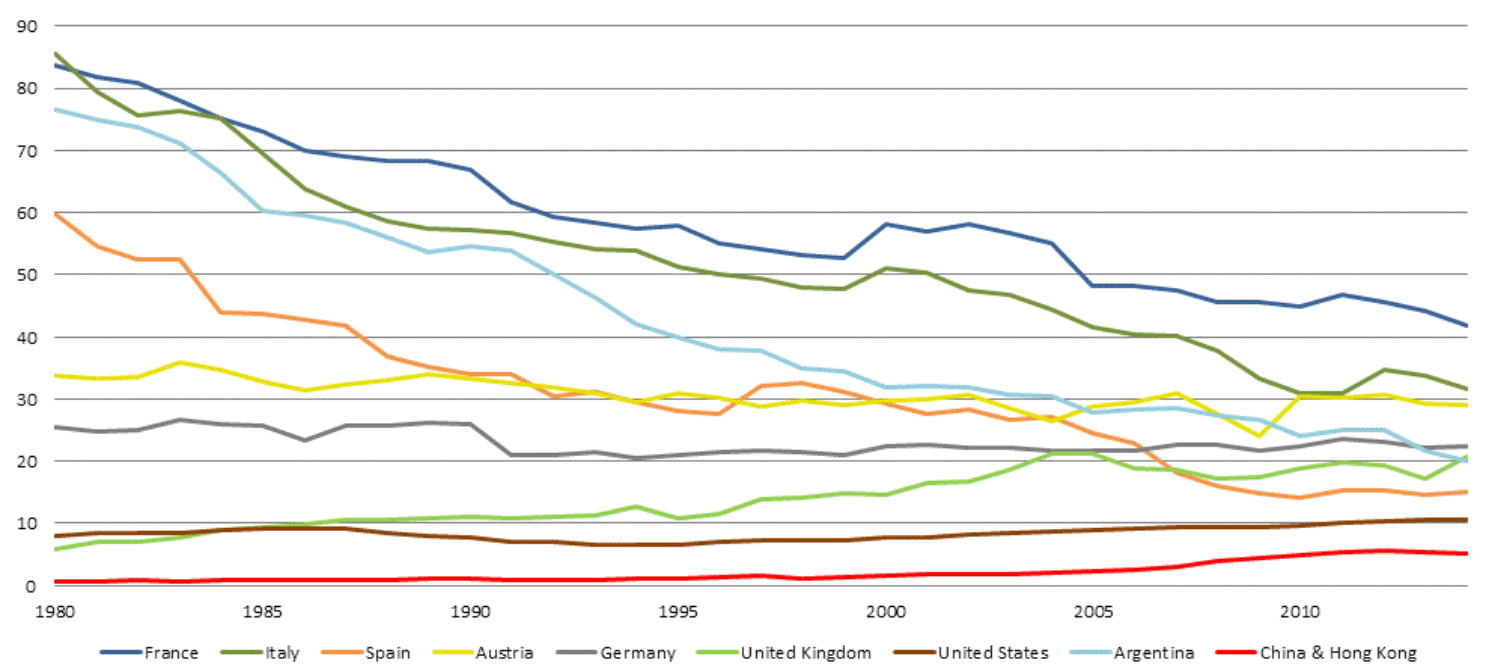

Source: Own figure based on (ANDERSON \& PINILLA, 2017) 


\section{Common Agricultural Policy}

Comparable to the whole agriculture sector, viniculture is heavily regulated in the EU. Over the last decades, the EU has implemented a wide range of policies. Quality and quantity, as well as the price of wine are affected by these regulations (MELONI \& SWINNEN, 2013: 246), which are now part of the single common market organisation (CMO). The $\mathrm{CMO}$ combines the market organisations for all different agricultural products in one enactment and is an essential part of the first pillar of the common agricultural policy (CAP). The purpose of the $\mathrm{CMO}$ is to support market activities of different sectors and to stabilise prices (EUROPEAN UNION, 2013). This is imperative for the wine sector as the per capita consumption in Southern Europe decreased rapidly over the last years leading to excess production.

The first approach to reduce the supply of wine was the subsidisation of distillation. The concept was introduced by the EU in 1970 (MELONI \& SWINNEN, 2013: 279) and lasted until 2012. Still, in crisis situations, MS are allowed to use national funds to support distillation (BETTINI, 2015: 21). In addition, the EU implemented a comprehensive enactment on planting rights for vineyards in 1976 (DG IPOL, 2012: 45).

Since then, the planting of new vineyards has been nearly banned completely, and many of the main wine producing countries have demanded to retain the planting rights to ensure a stable market, despite the EU's decision to liberalize the market in 2008. This strong lobby effort led to a new authorization system for planting rights, which was implemented in 2016 until the year 2030. Under the new system, a small growth of vineyard area is possible, if authorised. In contrast to the existing planting rights, these new authorizations cannot be traded and are individually granted. In addition, MS have some flexibility concerning the configuration of the system (MELONI \& SWINNEN, 2016: 400 FF).

As part of the 2008 reform of the wine $\mathrm{CMO}$, the grubbing-up of vineyards was subsidised from 2009 until 2011. This scheme encouraged structural change as it was mostly used by uncompetitive farms (EUROPEAN COMMISSION \& DG AGRI, 2012: 6). Due to low wine prices and financial difficulties, the scheme was widely accepted and reduced the wine production by $10 \mathrm{mhl}$ (BETTINI, 2015: 20; EUROPEAN COMMISSION \& DG AGRI, 2012: 4). 
Despite these regulations, wine production is still higher than wine consumption in Europe. Therefore, European winegrowers have become increasingly reliant on exports. Exports are encouraged by the CMO. For example, with the support measure "promotion on third country markets" which was introduced in 2008 (EUROPEAN COMMISSION \& DG AGRI, 2014: 26).

In the early days of the EU regulations, income maintenance for farmers and market intervention were priorities. Today, sustainable management of natural resources has become a major topic in the latest reform of the CAP which occurred in 2013 (DG AGRI, 2013: 4). Regarding wine, the reform largely maintained the CMO measures from the 2008 reform. MS can choose upon these measures; namely, the promotion in third countries, restructuring and converting vineyards, green harvesting, mutual funds, harvest insurance, investments, and/or by-product distillation. In addition, the measure innovation was implemented (EUROPEAN COMMISSION, 2016B).

Larger changes affect the direct payments which now entail a greening component. Greening includes the maintenance of permanent grassland, ecological focus areas and crop rotation, and accounts for $30 \%$ of the direct payments. A more sustainable and eco-friendly agriculture is further encouraged through the second pillar and the fund for rural development. For voluntary agri-environment measures (AEMs), a minimum of $30 \%$ of the budget is assigned (DG AGRI, 2013: 7). Since 1992 AEMs are positioned mandatory in the CAP and became a primary instrument for the conservation of biodiversity in agriculture (BATÁRY ET AL., 2015: 1008).

The rural development programs of each country or region can be shaped according to the specific regional conditions, but have to be congruent with at least four of the six priority objectives of the EU (DG AGRI, 2013: 9). Direct payments play a minor part in subsidies for viniculture, and permanent cultures are excluded from greening restrictions. However, MS have the possibility to implement AEMs which support sustainable viniculture, based on the flexible basic structure of the second pillar. Austria, for example, implements subsidies through its ÖPUL ${ }^{1}$ program for erosion control with CC in vineyards, and for the renouncement of insecticides and herbicides (LANDWIRTSCHAFTSKAMMER ÖSTERREICH, 2019).

\footnotetext{
${ }^{1}$ Austrian program for the promotion of environmentally friendly, extensive and natural habitatprotective agriculture
} 


\section{Studied wine regions}

The research areas were chosen by the national researcher teams of the VineDivers Project to which this thesis is associated. The selection was based on already existing connections to winegrowers and available data sets. In Figure 3-1 and the following section the relevant regions in Austria, France and Spain are described more closely.

Figure 3-1: Studied wine regions

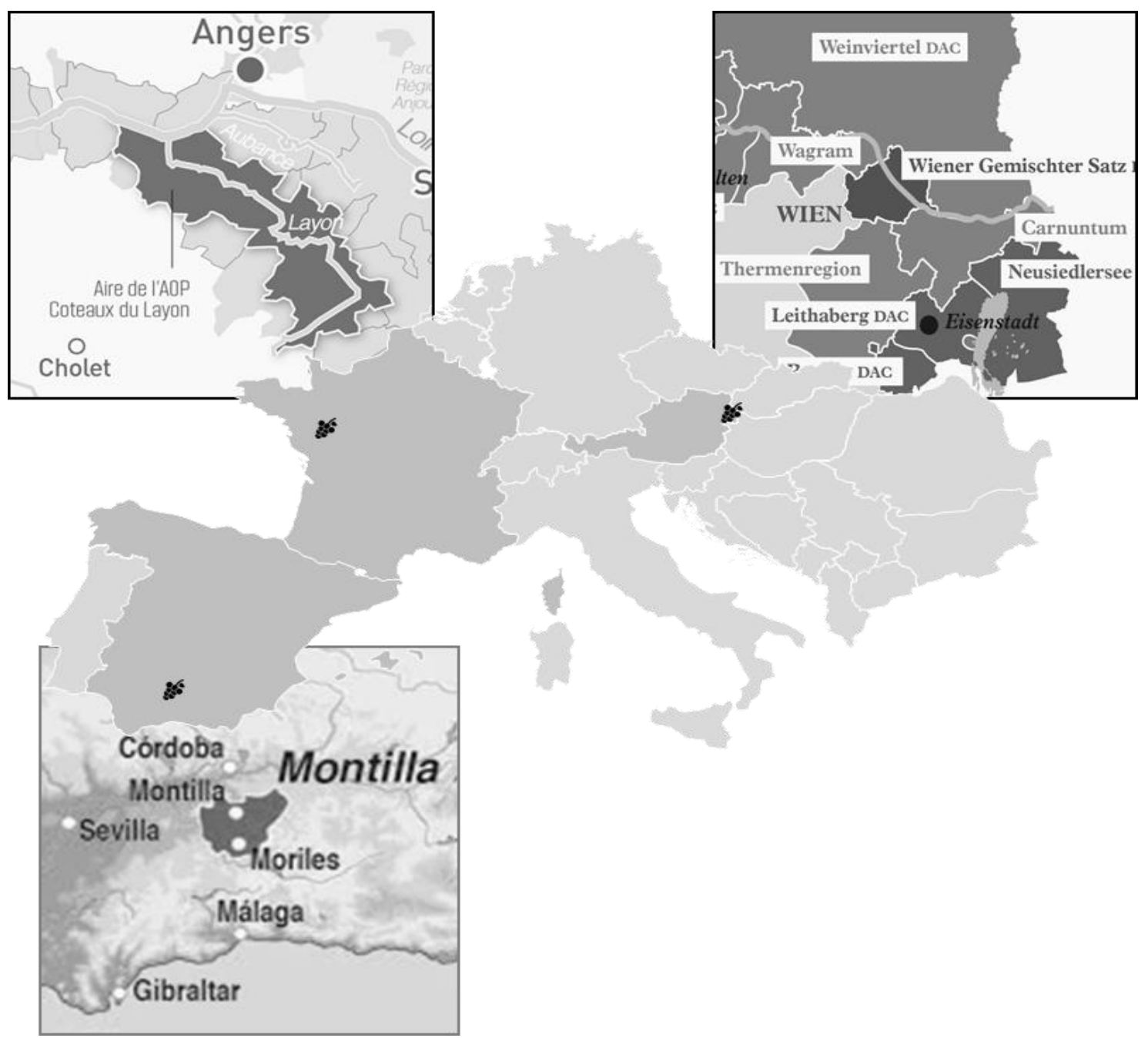

Source: Own figure based on: LAITHWAITE'S Wine, N.D.; LOIRE VALLEY Wine BUREAU, 2016; ÖSTERREICH WEIN, N.D.; PRESENTATIONGO, 2018

\section{Austria}

The research in Austria covers the regions of Carnuntum in Lower Austria (916 ha, 146 winegrowers) and Leithaberg (3022 ha, 569 winegrowers) in Northern Burgenland on an altitude of 164-285 m above sea level. The predominant soils in Carnuntum are loess and gravel (on the slopes), while limestone and mica schist define the soils in 
Leithaberg. The area is characterised by its Pannonian climate with cold winters and dry, warm summers (ÖSTERREICH WEIN, 2018A, 2018B, 2018C). The average temperature is $11.6^{\circ} \mathrm{C}$ and the annual precipitation reaches $473 \mathrm{~mm}$.

Though conventional winegrowers are the majority, herbicides are usually only used directly under the vines. Vegetation cover in the inter-rows is widely used and controlled with tillage or mulching. A common practice is cultivating permanent vegetation in every second inter-row and every other inter-row is tilled. All vineyards are rain-fed and traditional varieties are Grüner Veltliner (white) and Zweigelt (red) (WINTER, 2015). In Carnuntum, slightly more red wine (52\%) is produced, whereas white wine $(58 \%)$ is dominant in Leithaberg. The overall production of Leithaberg (Carnuntum) accounts for about $5 \%(2 \%)$ of the total Austrian wine production (ÖSTERREICH WEIN, 2018B: 36).

Based on the vicinity to Vienna and the recreational area of Neusiedler See, both regions are developed for touristic activities and the typical wine bars Heuriger are a popular destination. This touristic potential supports the direct marketing of the regional wines.

\section{France}

The region Coteaux du Layon in the Loire Valley, close to Angers, was chosen in France. This appellation is rather small (1620 ha, 300 winegrowers) and accounts for only $0.08 \%$ of the total French production with 38100 hectolitres (hl).

The climatic conditions are temperate oceanic and particularly dry, with an annual precipitation of $693 \mathrm{~mm}$. The slopes of the river Layon guarantee a good exposure and airflow. Schist and sandstone terraces are the basis for most vineyards, but they are also planted on brown, shallow Anjou Noir soil. The major variety is Chenin Blanc which is used to produce sweet white wines (LOIRE VALLEY WINE BUREAU, 2016, 2018A; METEO FRANCE, N.D.).

The majority of vineyards are managed conventionally and are rain-fed. Vegetation cover can be found in some vineyards but is not yet as common as in Austria. The region is developing its touristic potential with a wine route and wineries which offer tastings and wine for direct sale. Those wineries mostly carry the 'Vigneron Indépendant' label, which means that they manage their vines, mature and market their own wine. 


\section{Spain}

The Project Region in Spain, Montilla-Moriles, is located in Andalusia near the city of Cordoba on an altitude of 200-300 m above sea level. The semi-arid climate leads to hot and dry summers, and heavy rains in autumn and winter with an annual precipitation between $500-1000 \mathrm{~mm}$. Albariza is the major soil type. It has a low level of organic matter and a high level of calcium carbonate as well as a high water retention capacity (MONTILLA MORILES - El CLIMA, 2016). Olive plantations occupy most of the agricultural land and the region is strongly affected by structural change. The area under vine has decreased from nearly 20000 ha in 1979 to around 5000 ha in 2015 (JunTA DE ANDAluCia, 2003: 11; Ministerio DE AgRicultura, AlimentaCión y MediO AMBIENTE, 2016: 11). The area is distributed over 2160 winegrowers, reaching production levels of $276000 \mathrm{hl}$ of wine which is mostly consumed domestically. Therefore, $90 \%$ is sold on the national market. Due to the small-scale structure of vineyards, $65 \%$ of all grapes are processed in cooperatives (MONTILLA-MORILES, 2016). The soil management is traditionally shaped by intense and frequent tillage and spontaneous vegetation is only used on $11 \%$ of Andalusian vineyards (RAMÍREZ PÉREZ \& LASHERAS OCAÑA, 2016: 4, 6). The traditional vine cultivation system without trellis is still common; however, new vineyards use trellis systems. Organic wine production, or the use of $\mathrm{CC}$, is very rare and herbicides are used frequently. If vegetation cover is maintained, it is mostly temporary over the winter months. The regional adapted variety Pedro Ximénez is primarily grown and is used to produce a white wine, comparable to Sherry. This variety is produced in the near region Jerez.

In the following table the data of the research regions is summarized.

Table 3-1: Summary Research regions

\begin{tabular}{lrrrrrr} 
Region & ha & hl & \% of Country & hl/ha & Producer & ha/Producer \\
\hline Carnuntum & 916 & 43322 & $1.81 \%$ & 47 & 146 & 6.3 \\
Leithaberg & 3022 & 128056 & $5.34 \%$ & 42 & 569 & 5.3 \\
\hline Coteaux du Layon & 1089 & 38100 & $0.08 \%$ & 35 & 300 & 3.6 \\
\hline Montilla-Moriles & 5134 & 276314 & $0.69 \%$ & 54 & 2069 & 2.5 \\
\hline
\end{tabular}

Source: Own table based on: (LOIRE VALLEY WINE BUREAU, 2016; MONTILLA-MORILES, 2016; ÖSTERREICH WEIN, 2018B) 


\section{The Attitudes of French and Spanish Winegrowers towards the use of Cover Crops in Vineyards}

Rebekka Schütte and Holger Bergmann

This paper has been published in

Journal of Wine Research (c) 2019

https://www.tandfonline.com/doi/full/10.1080/09571264.2019.1568975 


\begin{abstract}
Vineyards are an intensive cultivation system and expose the soil to long-lasting stress. Many vineyard areas already show high degrees of soil degradation. To prevent further soil erosion, cover crops, which have various positive effects for the environment, are highly recommended. But, depending on the climatic conditions, cover crops can reduce grape yields and are sometimes more work intensive than bare soil management. In some areas cover crops are already widespread while in others bare soil is dominant. In this qualitative study, we explore the attitudes of European winegrowers towards cover crops and determine the background for differences in the adoption of greened vineyards. Thus, we conducted focus groups with winegrowers in two different regions, namely Coteaux du Layon in France and Montilla-Moriles in Spain. In this setting the transregional differences are mainly based on the climatic conditions but also on different business structures and knowledge levels. Direct sellers seem to be more attentive to the environment and use cover crops more often than farmers which sell their grapes to cooperatives.
\end{abstract}

\title{
Keywords
}

Cover crops, Focus group, Winegrower, Europe, Attitude

\section{Authorship Declaration}

The personal contribution to this article is above $80 \%$. 


\section{Results of the qualitative study in Austria}

In Austria one focus group with seven winegrowers from Carnuntum and Leithaberg took place. In addition one interview following the same questioning route was conducted. The participants manage between 6 and 100 ha of vineyards and the usage of CC is widely distributed. They designated themselves as a group which is rather interested in the whole biodiversity topic.

Overall the situation in regard to the conservation of the environment has improved over the last decades according to the participants and Carnuntum has been declared by them as a flagship region for ecological awareness.

\section{Factors determining cover crop usage}

$\mathrm{CC}$ are widely accepted by the participating winegrowers but they also pointed out the correlated difficulties. First of all, they admitted the additional workload for the CC management: 'Of course it is more work' (A8). Many businesses are family-operated but also rely on experienced permanent employees. In a labour peak contract workers can be employed but are commonly in short supply, because everyone needs them at the same time. A4: 'I am not a friend of temporary workers. If it has to be right now, if there are labour peaks, these peaks are everywhere and you often do not get the manpower.'

Moreover, the region has a low precipitation and therefore the competition of CC with the vines is a topic as A3 states: 'We stopped having clover under the vines. It might be fine for a few years but if you have a few dry years, the competition is just too big.'

Controlling CC under the vines is especially work-intensive and problematic. It is important to not wound the vines if the weeding is done mechanically. They explained that the choice of sown varieties is important and that the right timing of breaking up the soil, sowing and mowing is essential for an effective CC management. A6: 'We decide sort-and effect-dependent when to break the soil. Depending on how we assess the vineyard, what varieties we produce and how the precipitation is.' One needs to always control the vegetation, otherwise shrubs such as stinging nettles can establish.

Hence, profound knowledge is required for an effective CC management and A6 concludes: 'We just know more about the whole ecosystem now.'

A healthy soil is recognized as an important production factor: 'If you want quality, one somehow focuses more and more on the soil' (A8) and CC are accepted as beneficial for the 
soil. This utility is of relevance for A1: 'my personal argument is that it costs something. We do not do it because it is nice but because it is necessary.' Nevertheless some participants also revealed a personal interest in a greener vineyard: 'And of course you have all the wild bees there. And that shows up extremely. And that's cool' (A8).

In this region, which is orientated towards direct-selling, CC also fulfil a marketing purpose, as A1 says: 'There has been a development towards a more sustainable viniculture, because it is recognized and accepted by consumers.' A4 states: 'we sell more philosophy with the wine and the question is: how do consumers like it? Because they are more outdoors nowadays to see that, too.'

Overall, it was stated that 'the gap widens a bit between those who work very ecology-minded and those who only see the money', and the second group seems to be producers who focus on quantity.

\section{Factors determining the application of chemicals}

Even though the participants showed a high interest in an eco-friendly management, pesticides were not demonised and the necessity of those was admitted. For instance, A8 tries to be as organic as possible, but sometimes uses conventional pesticides, because he needs to ask himself 'what do I want to risk?'

However, the prophylactic usage is not common anymore and is also not recommended by the plant protection companies in such ways as it was done in former times. A1 stated: 'I have to say honestly, I used it [glyphosate], so I used it on a case-by-case basis. I did not use it prophylactically. Otherwise massive soil work would be needed. Which is better?'

The work simplification is admitted by A6: 'Herbicide free means more work and I saw that colleagues worked perfectly well with glyphosate. So I started using it too' and A4 acknowledges that 'if one stops using herbicides and insecticides it has to be technically possible.' Winegrowers in the region were successfully convinced, that the abandonment of insecticides is possible and to use pheromones instead. Still, this was due to efforts from some of the leading winegrowers in the region.

'If about 600 ha can be convinced, even conventional ones, that there is no more insecticide spraying. Then that's what really matters.' 
This shows that it is not always enough to change the management on some vineyards, but that neighbours have to work together. Also, constant efforts are necessary: 'It is especially difficult on smaller areas [drift from neighbouring lands] and some already changed back to insecticides.'

\section{Politics and the public}

In regard to politics the participants state that they are not strongly influenced by the CAP and are not reliant on it, which they appreciate. 'Luckily we are a sector which produces a semi luxury food and one may not be so dependent on agricultural policy because we make the prices ourselves. I think we are in a fortunate situation with direct marketing. Viniculture does not really need political support.'

AEMs are established in Austria but are considered too low, to really make a difference as another winegrower says: 'so you get a maximum of $200 € /$ ha. That's ridiculous. That is no incentive.' Accordingly, another stated that he is not using CC because of the subsidies but 'because I'm convinced of it myself.' He even backed out of an AEM once due to the restrictive regulations since 'you cannot work as you want.' He misses flexibility and the practical adaption of regulations since the soil management is very weather dependent. In addition it gives the farmer a feeling of not being trusted that he is able to do a good job, as one participant declares: 'I think it's really important to give people some leeway and place one's trust in them; that they know what they have to do.'

Farmers want to 'estimate by themselves when to do something and not just be trapped in regulations.' However, it was acknowledged that one 'has to accept the bureaucracy when applying for subsidies.'

\section{Future prospects}

All the participants perceive very positive future prospects for the regions. This is probably due to their favourable positioning on the market with quality wine. In addition they have regular customers and marketing opportunities in the nearby capital.

Yet one request was verbalized 'I wish that one, as a winegrower or farmer, is again more outside in the nature and does not has to spend more time in the office.' This might be a basic point for winegrowers in this region. They are fond of their work in the vineyards and have an intrinsic motivation to keep their land in good shape. 
In regard to a more sustainable viniculture the importance of knowledge was once again highlighted: 'I think that the most important thing is simply to create awareness for the people themselves and the exchange of experiences.'

\section{Conclusion}

The outcome of this focus group is comparable to the results of the French region. This might be due to a similar concentration on direct marketing and the production of quality wine.

Even though the participants seemed to have a high environmental awareness and widely adapted CC, they mentioned the same difficulties and risks as in the other studied regions. CC increase the work intensity and require a well-adjusted management in the vineyard. This can be a liability on family farms and under a shortage of workers as well as under uncertain climatic conditions.

On fertile soil CC are used as a valuable help to regulate the growth of vines and hence increase the quality of grapes. It became obvious once more that winegrowers need specific knowledge to successfully use vegetation cover in their vineyards and that pioneers can have a valuable influence on their colleagues.

AEMs are commonly known but are not taken as an adequate incentive to change the management and therefore are more or less a deadweight effect for the participating winegrowers. Probably, the influence of $\mathrm{CC}$ on marketing and the perception of consumers is of greater importance for the adoption. 


\section{Profitability of erosion control with cover crops in European vineyards under consideration of environmental costs}

Rebekka Schütte, Elke Plaas, Jose Alfonso Gómez, Gema Guzmán 


\section{Abstract}

Vine cultivation on slopes causes serious erosion with significant losses of nutrients, organic matter and water, followed by an overall loss of soil biodiversity and ecosystem services (ES). Cover crops (CC) in inter-rows can reduce these effects, but are often renounced by winegrowers due to economic causes. Soil erosion rates obtained from field data and simulations with ORUSCAL (Orchard RUSle CALibration) lay the basis for comparing three different scenarios of soil management; conventional tillage (CT), temporary cover crops (TCC) and permanent cover crops (PCC). We use the Policy Analysis Matrix (PAM) to include on- and off-side costs of erosion and to demonstrate their economic implications. The scenarios are calculated for two different European wine regions, Montilla-Moriles (Spain) and Carnuntum (Austria).

Results from ORUSCAL show that erosion is decreased in most cases with increasing use of vegetation cover. Overall, the consideration of erosion costs in the budget of farmers has only minor effects on their competitiveness and additional costs for CC are not covered by private erosion cost savings. If social erosion costs are added, CC are cost-effective in both regions. This is even without the valuation of non-marketed ecosystem services such as cultural and aesthetic aspects which most likely will increase social costs of erosion.

Furthermore, our results show that higher revenues are of greater importance for management decisions than lower input prices. Therefore, CC should be rewarded either through a higher willingness to pay from consumers or government support.

\section{Keywords}

Cover crops, Erosion costs, Winegrower, Vineyard, PAM, ORUSCAL

\section{Authorship Declaration}

The personal contribution to this article is above $80 \%$. 


\section{Introduction}

“Human survival and prosperity depend on adequate supplies of food, land, water, energy and biodiversity."

(PIMENTEL ET AL., 1995: 1121)

Inevitably, the supply of food through agriculture will always effect the environment and biodiversity and leads to significant costs per hectare (PRETTY ET AL., 2000: 118). How these negative effects could be reduced and their costs estimated are some of the urgent questions of our time.

A relevant negative effect in agriculture is erosion, particularly in vineyards which are often situated on slopes. Even though permanent crops account only for $2.6 \%$ of land cover in the EU, $10 \%$ of the total soil loss is located on this fields (PANAGOS ET AL., 2015). In regions with high intensity rainfalls for example in Andalusia (Spain), huge amounts of soil are washed away during autumn and spring and gullies are typical sights (RODRIGO COMINO ET AL., 2017). The intensity of rainfalls in Austria may increase as a consequence of climate change (KLIK \& EITZINGER, 2010) and increase water erosion. Erosion comprises not only a loss of soil, but rather includes a significant loss of nutrients, organic matter and water followed by an overall loss of soil biodiversity (PIMENTEL ET AL., 1995: 1120; PRETTY ET AL., 2000: 124). This affects the productivity of vines and the composition of the "terroir", being a relevant factor in wine production and marketing.

From an economic point of view, the consequences of erosion can be grouped in onand off-site costs, whereas on-site costs are borne by the farmer and include the productivity loss and restoration of soil properties. Off-site costs such as damages to infrastructure and the environment are borne by society (GALATI ET AL., 2015: 558; GÖRLACH ET AL., 2004: 10).

The extent of on- and off-site costs is determined by farming practices. Conservation technologies e.g. no tillage systems, mulching or the use of cover crops (CC) can reduce erosion significantly (BAGAGIOLO ET AL., 2018; GÓMEZ ET AL., 2011; RUíZ-COLMENERO ET AL., 2013). Soil properties such as soil organic carbon and aggregate stability can be improved with CC (GUZMÁN ET AL., 2019) and GALATI ET AL. (2015) shows that CC reduce the loss of nutrients and organic matter by $60 \%$. A meta-analysis has 
documented that CC have large positive effects on biodiversity and various ecosystem services (ES) (WINTER ET AL., 2018).

Nevertheless, conservation technologies are often associated by farmers with higher management costs and reduced competitiveness (MARQUES ET AL., 2015; SCHÜTTE \& BERGMANN, 2019). Especially as winegrowers usually only calculate their on-site costs and ignore the off-site costs. The most relevant consequence of erosion for farmers, a decreasing productivity, is showing merely in the long-term and can be deferred by increasing fertilizer use. At the average soil loss rate of $9.47 \mathrm{t} / \mathrm{ha}$ under permanent crops (PANAGOS ET AL., 2015: 442), it will take approximately 200 years until the fertile topsoil is lost completely.

Based on this unsustainable situation, there is a demand for societal actions. A main function of agricultural policy is to influence farming behaviour and policies can be used to decrease the negative external effects of agriculture (KYDD ET AL., 1997: 335). Hence, the Common agricultural policy (CAP) promotes agri-environment measures (AEMs) and for example subsidises soil conservation methods such as CC in vineyards. AEMs compensate farmers for voluntary conducted extensive management practices. Member states (MS) are individually responsible for the configuration of AEMs, thus their implementation is characterized by a large diversity across the EU. The contrast is obvious when focusing on the proportion ${ }^{2}$ of farmers receiving payments from AEMs which is highest in Austria (97\%) and lowest in Spain (3\%) (ZIMMERMANN \& BRITZ, 2016). However, these subsidies mostly cover the on-site costs of farmers and do not necessarily present a sufficient incentive for those to change their behaviour (GALATI ET AL., 2015).

The aim of this study is to create a better understanding about the environmental effects and the associated cost structure of erosion control in European Vineyards. It contributes to the ongoing political discussion about sustainability in agriculture and the economically reasonable assignment of subsidies.

For this study we compare different soil management scenarios in two different European wine regions, namely Montilla-Moriles in Spain and Carnuntum in Austria.

\footnotetext{
${ }^{2}$ Based on data from the Farm Accountancy Data Network (FADN) and the time period 2000-2009
} 
The changes in the profitability due to the adoption of CC and the prevention of erosion are calculated with a Policy Analysis Matrix (PAM), which is a budget-based analysis. Even though the PAM is a static methodology its strengths are the clear presentation of results and the easy comprehensibility, which makes them particularly accessible for stakeholders and useful for policy counselling. Results from ORUSCAL (Orchard RUSle CALibration) and experimental plots underline the calculation of the economic effects of CC for winegrowers and society.

\section{Material and Methods}

The data for this study was collected in two European wine regions, both labelled as a protected designation of origin (PDO), within the VineDivers project ${ }^{3}$.

The region Montilla-Moriles covers some 5000 ha close to Cordoba in Andalusia, Spain. Around 2000 winegrowers produce $276000 \mathrm{hl}$ of white wine of which $90 \%$ is placed on the national market (MONTILLA-MORILES, 2016). The soil is shaped by laminar structures and high carbonate content and Luvisols and Cambisols are the predominant soil types. The semi-continental Mediterranean climate leads to an average annual precipitation of $604 \mathrm{~mm}$ (range: 306-1 $012 \mathrm{~mm}$ ) and a mean annual temperature of $17.2^{\circ} \mathrm{C}$ (GUZMÁN ET AL., 2019). The economic situation for the businesses is tough as grapes are sold mostly to cooperatives and the region competes with the area of Jerez which produces similar wine, but is better known on the market. Additionally, more profitable olive and almond orchards are competing for land. Therefore, the cultivated area and the number of winegrowing businesses were reduced by half since 2000 (Ministerio De AgRicultura, Pesca y Alimentación, N.D.).

Carnuntum is a small PDO of roughly 900 ha under vine and about 150 winegrowers, which is close to the Austrian capital Vienna. Loess and gravel (on the slopes) are the predominant soils and the area is characterized by its Pannonian climate with cold winters and dry, warm summers (ÖSTERREICH WEIN, 2018A). The average temperature is $11.6^{\circ} \mathrm{C}$ and the annual precipitation reaches $473 \mathrm{~mm}$ (WINTER, 2015). The production amounts to $43000 \mathrm{hl}$, about half white and red wine (ÖSTERREICH WEIN, 2018B: 36).

\footnotetext{
${ }^{3}$ www.vinedivers.eu
} 
Due to its touristic attractiveness and proximity to Vienna, the region is oriented towards direct marketing and many winegrowers produce their own wine.

\section{Orchard RUSle CALibration (ORUSCAL)}

ORUSCAL is an EXCEL tool which allows the calibration of RUSLE2 (DABNEY ET AL., 2012) by assuming a simplified situation of an homogeneous hillslope. The structure is defined in Appendix A. Each of the factors of RUSLE2 is calculated in one (e.g. R) or several (e.g. C) Excel sheets. Each factor is accompanied by a set of explanations. The sheets contain information, or the procedures for finding that, to allow the user to include the required data and to calibrate the parameters. All the equations and units have been revised to agree with those employed in RUSLE2.

The assumption is that with basic information on rainfall, temperature, crop evolution, canopy and ground cover, tillage and topography it is possible to calibrate RUSLE2, considering the interactions among different factors and sub-factors, in a relatively easy way. This can facilitate understanding the erosion risk of different management practices by stakeholders, or more sophisticated uses such as comparison of erosion risk among different management, soil, temperature and rainfall regimes. For more complex situations, e.g. complex slope profiles, the user should calibrate the RUSLE2 software. The literature shows a wide variability among soil cover and management (C) factors for vineyards from different sources (AUERSWALD \& SCHWAB, 1999; KOULI ET AL., 2009; NOVARA ET AL., 2011; PACHECO ET AL., 2014) which complicates their interpretation and extrapolation outside the area where they were developed. Therefore this model provides a tool to perform erosion studies in vineyards using a standardize procedure.

The models were evaluated calibrating ORUSCAL for two different types of soil management (PCC and CT) for the conditions of the long-term runoff plot experiment described by (BIDDOCCU ET AL., 2016) in North Italy using four different calibration strategies:

a) Constant $\mathrm{K}$ value calculated from soil properties from the nomograph used by standard RUSLE, and consideration of soil moisture (sm) variation during the year using the sm subfactor of the cover and management factor $\mathrm{C}$. 
b) Constant $\mathrm{K}$ value, calculated from soil properties from the nomograph, and the sm subfactor in $\mathrm{C}$ was not considered.

c) Variable K value, using the empirical function based on $T^{\mathrm{a}}$ and rainfall included in RUSLE and baseline $\mathrm{K}$ calculated from soil properties from the nomograph. The sm subfactor is not considered as indicated by RUSLE handbook.

d) Constant $\mathrm{K}$ value calculated from soil properties based on the model proposed by BORSELLI ET AL. (2012), and consideration of sm variation during the year using the sm subfactor of the cover and management factor $\mathrm{C}$.

The results (GÓMEZ ET AL., 2018) showed that the best calibration strategy are calibration strategies a) and d). Once evaluated, the model was used to develop erosion scenarios, using the calibration option a) for both regions. In each region the topographic, soil, cover and management information required for calibration of ORUSCAL was taken from field survey sampling 16 vineyards at each area. These vineyards were chosen to have eight in each of the two most common soil management techniques in the region (low or high intensity in terms of encouraging ground cover in the alleys or not, respectively). Climate data were taken from nearby weather stations. Rainfall erosivity ( $\mathrm{R}$ factor) was calculated using an empirical expression from daily rainfall and daily erosivity calibrated to provide similar annual results to those obtained from BALLABIO ET AL. (2017) to prevent bias in R determination across regions. Three different managements were considered, bare soil by tillage (CT), temporary cover crops (TCC) and permanent vegetation cover (PCC). TCC in Spain means cover crops in the field only during fall and winter and in the Austrian case cover crops the whole year in every second inter-row (with tillage in every other interrow). Example pictures can be seen in Figure 6-1. In both regions each of these scenarios were analysed through running simulations for 16 years at eight respectively 16 plots at each site. We run eight plots for management in which this management were present (e.g. TCC in Austria) while the 16 plot simulations we run in cases when this management was not present (e.g. TCC in Spain) and a hypothetical scenario was run. 


\section{Figure 6-1: Example pictures of the scenarios}
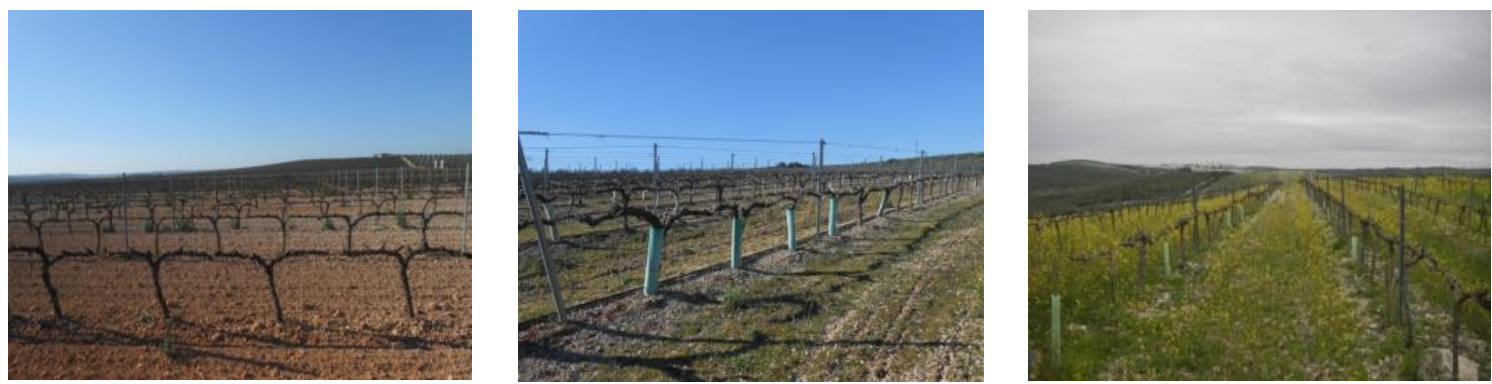

From left to right: bare soil by tillage (CT), temporary cover crops (TCC), and permanent vegetation cover (PCC). Source: (GÓMEZ ET AL., 2018)

\section{Policy analysis matrix}

In contrast to computable general equilibrium models (CGE) the PAM concentrates on one specific commodity system. This partial equilibrium approach has moderate demands on the amount of data required and can be conducted in a shorter period of time (HARTMANN ET AL., 1993: $71 \mathrm{~F}$ ). This makes the method remarkably attractive in the context of data and time limitation. Despite the simplification, it leads to reasonable results and has been proven useful in many agricultural studies over the last decades (E.G. NelsON \& PANGGABEAN, 1991; YAO, 1997; KRABBE \& VINK, 2000; PEARSON ET AL., 2003; LAKEMEYER, 2007; ABDUL FATAH, 2017).

The basic PAM as shown in Table 6-1 consists of three rows, whereby the first two rows display the private and social prices. The third row shows the divergences between the first two. These divergences are the results of either market-distorting policies or market failure, e.g. external effects (MONKE \& PEARSON, 1989: 14). The competitiveness of a production system can be spotted easily in this matrix. The private profit (D), if not positive, should at least be equal to zero. Otherwise the producer will probably cease production (MONKE \& PEARSON, 1989: 12). If D is positive but the social profit $(\mathrm{H})$ is negative, the production system is only operating due to the protection of the government (MONKE \& PEARSON, 1989: 17). 
Table 6-1: The Policy Analysis Matrix

\begin{tabular}{lcccc} 
& Revenues & \multicolumn{2}{c}{ Costs } & Profit \\
& & Tradable Inputs & Domestic Factors & \\
Private Prices & $A=p_{i}^{p}$ & $B=\sum_{j=1}^{k} a_{j i} p_{j}^{p}$ & $C=\sum_{j=k+1}^{n} a_{k i} p_{k}^{p}$ & $D=\pi_{i}^{p}=A-B-C$ \\
& & $F=\sum_{j=1}^{k} a_{j i} p_{j}^{s}$ & $G=\sum_{j=k+1}^{n} a_{k i} p_{k}^{s}$ & $H=\pi_{i}^{s}=E-F-G$ \\
\hline Social Prices & $E=p_{i}^{S}$ & $K=C-G$ & $L=D-H=I-J-K$
\end{tabular}

Source: Monke and Pearson, 1989, p. 11

For constructing a PAM, information about input and output prices of production is needed. Information for private prices is obtained from farm budgets. Social prices have to be estimated. For tradable inputs, world prices adjusted by marketing costs are usually a good assumption. Social opportunity costs are used for non-tradable inputs such as labour and land (PEARSON ET AL., 2003: 19 F). The data collection and creation of budgets is probably the most work intensive part of the PAM.

The PAM is an approach to not only measure price distortions but also comparative advantages. This approach enables a comparison of private profitability before and after policy changes and displays the influence of these changes on the competitiveness in market prices. It is a simple but effective way of showing differences between actual prices (private prices) and presumed prices without any market-distorting policies (social prices) (MONKE \& PEARSON, 1989: 11). Moreover, KYDD ET AL. (1997) demonstrates that it is possible to take monetary valued environmental effects into account. In our analysis we added on-site costs of erosion as a non-tradable private factor and off-site costs as non-tradable social factor to the matrix in the scenarios CT, TCC and PCC. The Basic scenario presents a CT scenario without considering erosion costs. Eventually, the matrix entries can be used to calculate some helpful indicators. These parameters are necessary for comparing different countries or production systems and are presented in Table 6-2 (MONKE \& PEARSON, 1989: 16). 
Table 6-2: Parameters calculated from the PAM

\begin{tabular}{lcc} 
Parameter & Abbreviation & Calculation \\
\hline Social Cost Benefit & $\mathrm{SCB}$ & $(\mathrm{F}+\mathrm{G}) / \mathrm{E}$ \\
Private Cost Benefit & $\mathrm{PCB}$ & $(\mathrm{B}+\mathrm{C}) / \mathrm{A}$ \\
\hline $\begin{array}{l}\text { Nominal Protection Coefficient on } \\
\quad \text { Outputs }\end{array}$ & $\mathrm{NPCO}$ & $\mathrm{A} / \mathrm{E}$ \\
$\quad$ Inputs & $\mathrm{NPCI}$ & $\mathrm{B} / \mathrm{F}$ \\
Effective protection coefficient & $\mathrm{EPC}$ & $(\mathrm{A}-\mathrm{B}) /(\mathrm{E}-\mathrm{F})$ \\
\hline Domestic Resource Cost & $\mathrm{DRC}$ & $\mathrm{G} /(\mathrm{E}-\mathrm{F})$ \\
Private Cost Ratio & $\mathrm{PCR}$ & $\mathrm{C} /(\mathrm{A}-\mathrm{B})$
\end{tabular}

Source: Own figure after MONKE and PEARSON (1989, p. 12) and NIVIEVSKYI (2009, p. 135)

The social cost benefit (SCB) as well as the domestic resource cost (DRC) are used to calculate the comparative advantage of a production system. The private cost ratio (PCR) is the equivalent to the DRC in private prices, whereas the private cost benefit (PCB) is the counterpart to the SCB. As (MASTERS \& WINTER-NELSON, 1995) indicate, the DRC (and consequently the PCR) is influenced by the amount of domestic factors which are used by a commodity system and thus the SCB (equally PCB) is a more suited alternative. In addition, the DRC is discontinuous where $\mathrm{E}=\mathrm{F}$, which complicates the interpretation. The advantages and disadvantages of these two indicators have also been discussed by (NIVIEVSKYI \& VON CRAMON-TAUBADEL, 2009). Hence, we focus on the SCB and PCB in the results ${ }^{4}$.

The nominal protection coefficients for output (NPCO) and input (NPCI) reveal price distortions in the respective markets. The effective protection coefficient (EPC) combines the NPCO and the NPCI and shows overall effects of price distortions (LAKEMEYER, 2007: 94 F).

\section{Material}

To construct the PAM, we use average primary as well as secondary data, adjusted by inflation for the year 2016. Primary data was collected during field trips and personal interviews with practitioners from the regions. Grey literature is the main source for secondary data e.g. official statistics provided by regional institutions and the EU. As key sources for secondary budget information in Spain we used data from Junta de Andalucia (JunTA DE ANDAluCiA, 2003, 2018) and (AlCÁZAR, 2011). For Austria we

\footnotetext{
${ }^{4}$ For the sake of completeness, the DRC and PCR can be found in the Appendices.
} 
mainly used data from a gross margin calculator (BUNDESANSTALT FÜR AGRARWIRTSCHAFT, N.D.). Erosion costs are calculated based on soil loss rates from regional experimental results and simulations with ORUSCAL as well as previous estimations from literature. The estimations of GÖRLACH ET AL. (2004) were established through a profound literature analysis and additional field studies and are shown in Table 6-3.

Table 6-3: Costs per ton of soil loss in year 2016

\begin{tabular}{|c|c|c|c|c|c|}
\hline \multirow[b]{2}{*}{ In EUR } & \multicolumn{2}{|c|}{ On-site costs } & \multicolumn{2}{|c|}{ Off-site costs } & \multirow[t]{2}{*}{ Total } \\
\hline & $\begin{array}{l}\text { Private } \\
\text { Cost }\end{array}$ & $\begin{array}{c}\text { Private } \\
\text { mitigation }\end{array}$ & $\begin{array}{l}\text { Social } \\
\text { Cost }\end{array}$ & $\begin{array}{c}\text { Damage } \\
\text { avoidance }\end{array}$ & \\
\hline Upper bound (B) & 3 & 8 & 49 & 7 & 68 \\
\hline $\begin{array}{l}\text { Intermediate (adj. } \\
\text { Mean) (A) }\end{array}$ & 2 & 1 & 25 & 7 & 35 \\
\hline Lower bound & 0 & - & 3 & - & 3 \\
\hline
\end{tabular}

Based on data from (GÖRLACH ET AL., 2004) for vineyards with an average soil loss rate of 19.97 t/ha/year. Adjusted for inflation.

The costs are divided in on- and off-side costs which present in the former private costs and social costs in the latter. The estimations of GÖRLACH ET AL. (2004) are used in case A and case B. The estimation of crop productivity loss also follows PANAGOS ET AL. (2018: 478), who estimated an annual productivity loss per ha of $0.797 \%$ for Spain and $0.888 \%$ for Austria due to erosion, based on arable crops. Additional data is derived from MARTínEZ-CASASNOVAS \& RAMOS (2006). In that study the costs for maintenance of drainage systems and the filling of gullies in Italian vineyards are valued at $180 € /$ ha or $5.4 \%$ of the annual revenue. This data is used as the basis for calculating case $\mathrm{C}$.

The amount of subsidies per hectare derives from ANDERSON \& JENSEN (2016) who estimated the entire support European wine producers received between 2007-2012. A considerable amount of subsidies in viniculture is paid for promotion activities which might not affect grape growers directly but wine producers and trading businesses. This aspect has been considered in the interpretation of the results.

According to the OECD (2018: 195) nearly $50 \%$ of the subsidies European farmers receive under pillar I are linked to mandatory environmental requirements e.g. cross compliance and greening. However, permanent cultures such as vineyards are 
exempted from greening regulations (ALLIANCE ENVIRONMENT \& THÜNEN INSTITUTE, 2017: 223) and winegrowers must only act according to the basic rules of cross compliance to receive direct payments (EUROPEAN COMMISSION, 2015A). This also applies for farmers under the Small Farmers Scheme who receive a maximum payment of $1250 €$ per farm. Under pillar II farmers can participate in voluntary AEMs to receive payments for additional environmental services which account for another $8 \%$ of the total producer support (OECD, 2018: 195). In Spain organic winegrowers can receive an additional payment of about $95 € /$ ha if they obtain $C C$ at least in every second inter-row from October to March and the slope is above $20 \%$ (RAMÍREZ PÉREZ \& LASHERAS OCAÑA, 2016: 22 F). In Austria every winegrower can receive 100-800 €/ha for maintaining CC, depending on the slope. TCC over the winter are only eligible on slopes under $25 \%$. On steeper slopes PCC have to be used (AMA, 2015). In both countries the size of the vineyard must be at least 0.5 ha to be eligibility.

The models describe small family farms ${ }^{5}$ in the study regions and are in each case calculated for one ha of vineyard on moderate slopes with a trellis system and no irrigation. The budgets can be found in the appendices. The distribution of costs is relatively similar in both study regions as can be seen in Figure 6-2.

\section{Figure 6-2: Cost structure of grape production}

\section{Montilla Moriles}

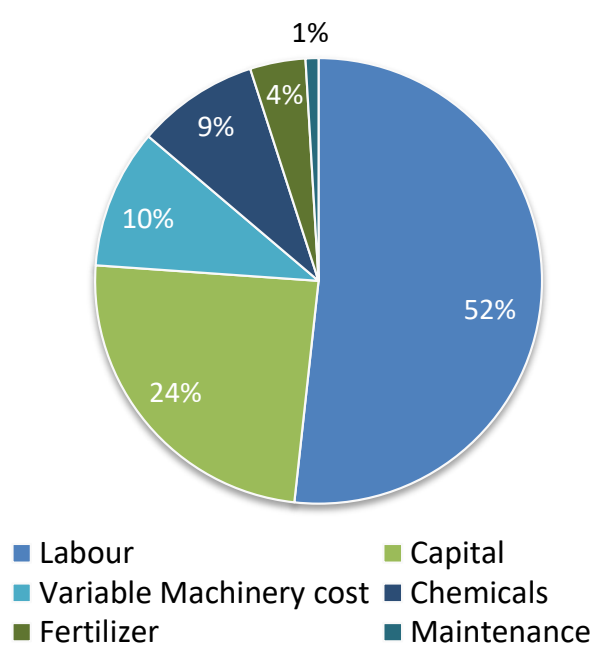

\section{Carnuntum}

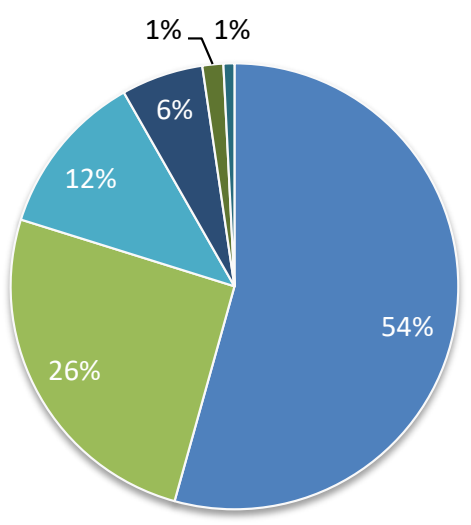

\footnotetext{
${ }^{5}$ The average farm size in Montilla-Moriles is 2.3 ha and in Carnuntum: 6.2 ha.
} 
Labour, which accounts for more than half of the budget, and capital costs (around a quarter) are the most important cost categories. The share of capital costs includes the amortisation of the vineyard. In Austria we find a slightly higher proportion of labour costs. This can be related to higher quality grapes which require more pruning and canopy work. The third largest cost category is variable machinery cost, closely followed by chemicals. Fertilizer and maintenance of the vineyard are minor categories.

\section{Results and Discussion}

Overall, as can be seen in Figure 6-3, when comparing the scenarios Basic and CT, the consideration of erosion costs has only a slight effect on the ratios derived from the PAM in both regions. Accordingly, the management change towards TCC and PCC does not represent a serious economic threat to businesses, especially since the erosion costs are most likely to decrease with increasing use of CC.

\section{Figure 6-3: SCB and PCB Ratios for Austria and Spain}

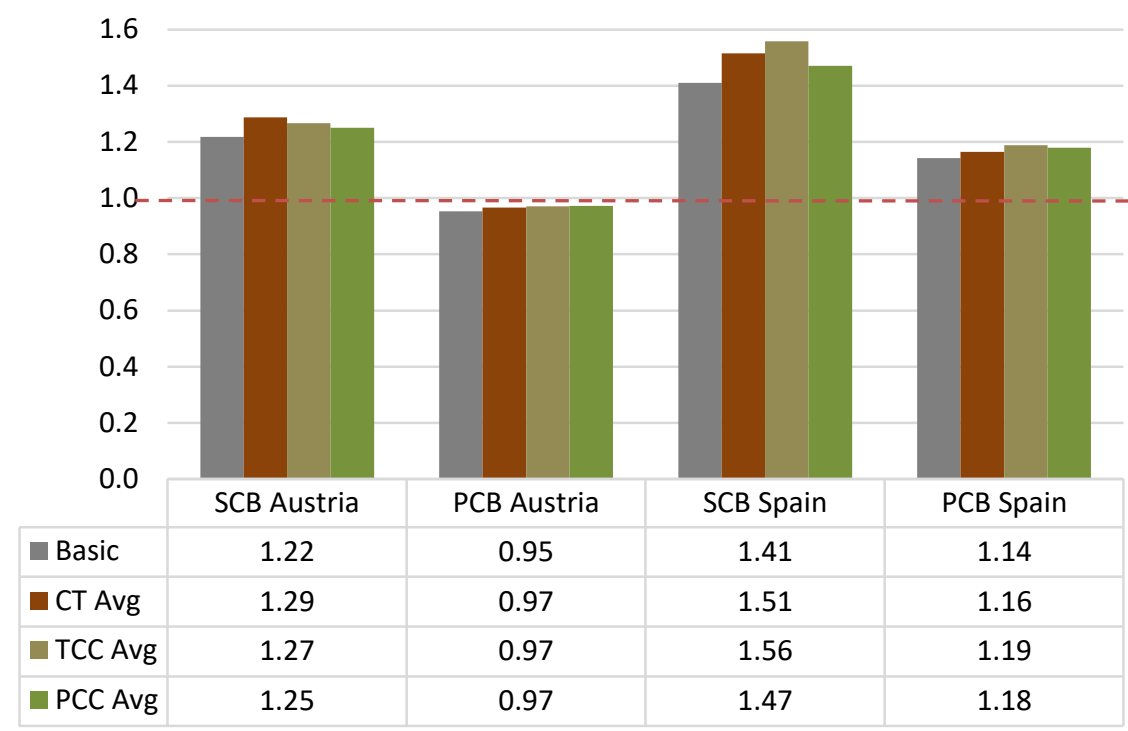

Scenarios include Subsidies. Basic PCB Austria w/o subsidies: 1.23; Basic PCB Spain w/o subsidies: 1.28

\section{Spain}

Under consideration of all costs and a grape price of only $0.30 € / \mathrm{kg}$, a small grape grower in Montilla-Moriles is not profitable. However, the yield covers the variable costs. The SCB of 1.41 demonstrate no competitive advantage for this industry. Under the given cost structure at least $0.41 € / \mathrm{kg}$ of grapes would be needed to cover full costs 
(SCB: 1). Certainly, any consideration of additional costs will worsen the economic situation of these grape growers.

If the farmer is able to receive the full amount of subsidies according to ANDERSON \& JENSEN (2016) the NPCO reaches 1.12. In reality most of the small grape growers do not apply for subsidies due to bureaucratic barriers. Also, a major amount of subsidies is assigned for marketing and investments into cellars, which do not affect grape growers. Therefore, the inclusion of subsidies is more of a hypothetical scenario and illustrates a best case for farmers.

The erosion simulation for Montilla-Moriles resulted in an average erosion rate under TCC (9.53 t/ha/y) slightly higher than under CT (7.14 t/ha/y) which is contrary to the hypothesis that greened vineyards always reduce soil erosion. This deviation is an indicator for the many different aspects (e.g. slope, rainfall events and intensity) which are involved in erosion, besides $\mathrm{CC}$, and the heterogeneity in the field sites as described by GUZMÁN ET AL. (2019). Hence, the result of the simulation does not necessarily have universal validity for the region. Nevertheless, the average soil loss rate under PCC (1.64 t/ha/y) is substantial lower than under CT and follows the basic hypothesis. As noticed previously, CC bring along a series of benefits to the ecosystem and biodiversity (WINTER ET AL., 2018) besides erosion control, and hence are always the superior management option from an environmental point of view.

The scenarios TCC and PCC are linked to increasing management costs which account for $2.3 \%$ (TCC) respectively $4.5 \%$ (PCC) of the variable costs. In Table $6-4$ one can clearly see that under the solely consideration of private costs, it is unprofitable for a grape grower to change the management. From a social perspective however, PCC management saves more than it costs.

Table 6-4: Changes in Erosion Costs compared to CT (Montilla-Moriles)

\begin{tabular}{llrr} 
In EUR & & TCC & PCC \\
\hline & Management cost CC & +66 & +126 \\
\hline Change in & Private avg. & +29 & -68 \\
$\begin{array}{l}\text { Erosion } \\
\text { cost }\end{array}$ & Social avg. & +82 & -278 \\
\hline
\end{tabular}

Considering that the estimated costs of erosion fail to incorporate non-market values such as biodiversity and aesthetics, the real total costs of erosion are most likely higher 
than assumed in this study and could thus make also the TCC scenario economically reasonable. The incentive for maintaining CC in vineyards through AEMs can be considered as very low. For the payment of $95 € /$ ha many liabilities must be respected e.g. vineyards have to be ecological and on slopes over $20 \%$ (RAMíREZ PÉREZ \& LASHERAS OCAÑA, 2016). In return at least the management costs for TCC are covered.

\section{Austria}

The situation for grape growers in Carnuntum is better than that of their colleagues in Montilla-Moriles with a grape price of $0.90 € / \mathrm{kg}$ and a SCB of 1.22 , but is still not competitive. They require a minimum price of $1.10 € / \mathrm{kg}$ to reach competitiveness (SCB: 1). Following ANDERSON ET AL. Austrian winegrowers receive more subsidies (NPCO: 1.29) than their Spanish peers and can thus achieve private profitability with a PCB of 0.95 . In Austria, many winegrowers generate added value by producing and selling their own wine, which improves their profitability and will also have a positive effect on the SCB.

Experimental Data on Erosion rates in Carnuntum ${ }^{6}$ show a continuously decline with the usage of CC which has been verified through ORUSCAL simulations. The changed management comes with $1.8 \%(2.7 \%)$ additional costs for TCC (PCC) but, as can be seen in Table 6-5, they are exceeded by the saved social erosion costs.

Table 6-5: Changes in Erosion Costs compared to CT (Carnuntum)

\begin{tabular}{llrr} 
In EUR & & TCC & PCC \\
\hline & Management cost CC & +122 & +189 \\
\hline $\begin{array}{l}\text { Change in } \\
\begin{array}{l}\text { Erosion } \\
\text { cost }\end{array}\end{array}$ & Private avg. & -69 & -115 \\
\hline
\end{tabular}

Similar to the scenarios in Spain, from a private perspective the management change is not profitable. Indeed, winegrowers can participate in the AEM "erosion control" and are eligible for payments of $100-800 € /$ ha depending on the slope of the vineyard. On moderate slopes $200 € /$ ha are paid for PCC (AMA, 2015). This covers the additional management costs but does not give a further financial incentive or incorporates social costs of erosion, this coincides with the results of GALATI ET AL. (2015).

${ }^{6}$ CT: 9.7 t/ha/y; TCC: 4.7 t/ha/y; PCC: 1.4 t/ha/y 


\section{Sensitivity Analysis}

Even though the PAM has clearly some practical advantages, it should be kept in mind, that it is a static approach, based on a Leontief production function. Changing production decisions based on price alterations cannot be considered. In addition, it is particularly difficult to estimate valid quantities and prices for the underlying budgets. The model is unable to depict the variability of agricultural prices and the transmission of world prices to domestic prices can be deficient (MORRISON \& BALCOMBE, 2002: 462). Thus, to show in detail how the SCB is affected by particular factors, we conducted a sensitivity analysis on the output price as well as labour, variable machinery and erosion costs. As expected, Table 6-6 shows that a change of output prices influences competitiveness more than changing input prices. It is therefore crucial for winegrowers to gain higher prices, if they want to stay on the market.

This is often realized not by selling grapes but through producing wine and engaging in direct marketing. During that process most of the value is added and prices of bottled wine show a tremendous range. This cannot be explained solely by different qualities but especially by successful marketing. In the touristic development of wine regions lies a major potential to establish higher prices and the use of CC can have an additional effect, considering the ongoing trend for sustainable consumption.

If higher prices cannot be realized on the market, additional incentives through AEMs could reward environmental services by winegrowers. However, one needs to be aware that winegrowers might not adopt these measures at the extent intended. Intensively managed lands, small scale farms, a high share of family labour and reliance on agricultural income all reduce the willingness to adopt AEMs (LASTRABRAVO ET AL., 2015; ZIMMERMANN \& BRITZ, 2016) but are characteristics of vineyards in the studied regions.

Apart from that, the implementation of financial aid for environmental services in agriculture can be criticized and offers space for discussions. AEMs imply that policy has decided that winegrowers have the right to exploit their land and should be compensated for environmental services instead of ascribing society a right for a healthy environment. This allocation of property rights developed historically and is not uncritical (BROMLEY \& HODGE, 1990). The question of property rights has been 
widely discussed in environmental economics. Following COASE (1960) it does not matter who owns these rights as negotiations will always lead to an efficient allocation of resources. However, Coase's concept is of theoretical nature and does not hold true in a realistic setting with transaction costs and information asymmetries. CERIN (2006: 222) comes to the conclusion that environmental related altruistic behaviour cannot be expected of companies, particularly if it is not appreciated by consumers. Hence, in its current state, the CAP acknowledges that "farmers should be rewarded for the services they deliver to the wider public, such as landscapes, farmland biodiversity, climate stability even though they have no market value" (DG AGRI, 2013:5).

As indicated by winegrowers and derived from the cost share of labour, this factor has the second biggest effect on competitiveness in both regions. A moderate increase in labour due to CC does not have a significant effect on the SCB ratio and indicates that it should be acceptable in respect of the gain in ES.

An alteration of the estimated erosion costs however does not influence the SCB substantially. This strengthens the previous presented results and highlights the minor consequences of erosion costs for the profitability of vineyards. It also points out that even if winegrowers have to incorporate the estimated on- and off-site costs of erosion in their budget, it does not mean that the management is instantly changing to a more sustainable option. 
Table 6-6: Sensitivity Analysis for SCB

\begin{tabular}{|c|c|c|c|c|c|c|c|c|}
\hline \multirow{3}{*}{$\begin{array}{l}\text { Scenario } \\
\text { Change } \\
\text { in... }\end{array}$} & \multicolumn{4}{|c|}{ CT } & \multicolumn{4}{|c|}{ PCC } \\
\hline & \multicolumn{2}{|c|}{ Spain } & \multicolumn{2}{|c|}{ Austria } & \multicolumn{2}{|c|}{ Spain } & \multicolumn{2}{|c|}{ Austria } \\
\hline & SCB & $\triangle \mathrm{SCB}$ & SCB & $\triangle \mathrm{SCB}$ & SCB & $\Delta \mathrm{SCB}$ & SCB & $\triangle \mathrm{SCB}$ \\
\hline \multicolumn{9}{|c|}{ Output Price } \\
\hline $80 \%$ & 1.84 & $25 \%$ & 1.57 & $25 \%$ & 2.28 & $25 \%$ & 1.48 & $25 \%$ \\
\hline $90 \%$ & 1.63 & $11 \%$ & 1.40 & $11 \%$ & 2.03 & $11 \%$ & 1.31 & $11 \%$ \\
\hline $110 \%$ & 1.34 & $-9 \%$ & 1.14 & $-9 \%$ & 1.66 & $-9 \%$ & 1.08 & $-9 \%$ \\
\hline $120 \%$ & 1.23 & $-17 \%$ & 1.05 & $-17 \%$ & 1.52 & $-17 \%$ & 0.99 & $-17 \%$ \\
\hline $150 \%$ & 0.98 & $-33 \%$ & 0.84 & $-33 \%$ & 1.22 & $-33 \%$ & 0.79 & $-33 \%$ \\
\hline \multicolumn{9}{|c|}{ Variable machinery costs } \\
\hline $80 \%$ & 1.45 & $-1 \%$ & 1.23 & $-2 \%$ & 1.80 & $-2 \%$ & 1.15 & $-2 \%$ \\
\hline $90 \%$ & 1.46 & $-1 \%$ & 1.25 & $-1 \%$ & 1.81 & $-1 \%$ & 1.17 & $-1 \%$ \\
\hline $110 \%$ & 1.48 & $1 \%$ & 1.27 & $1 \%$ & 1.84 & $1 \%$ & 1.20 & $1 \%$ \\
\hline $120 \%$ & 1.49 & $1 \%$ & 1.29 & $2 \%$ & 1.85 & $2 \%$ & 1.21 & $2 \%$ \\
\hline $150 \%$ & 1.52 & $3 \%$ & 1.33 & $5 \%$ & 1.90 & $4 \%$ & 1.25 & $6 \%$ \\
\hline \multicolumn{9}{|c|}{ Labour costs } \\
\hline $80 \%$ & 1.36 & $-8 \%$ & 1.13 & $-10 \%$ & 1.68 & $-8 \%$ & 1.07 & $-10 \%$ \\
\hline $90 \%$ & 1.41 & $-4 \%$ & 1.20 & $-5 \%$ & 1.76 & $-4 \%$ & 1.13 & $-5 \%$ \\
\hline $110 \%$ & 1.53 & $4 \%$ & 1.32 & $5 \%$ & 1.90 & $4 \%$ & 1.24 & $5 \%$ \\
\hline $120 \%$ & 1.58 & $8 \%$ & 1.39 & $10 \%$ & 1.97 & $8 \%$ & 1.30 & $10 \%$ \\
\hline $150 \%$ & 1.75 & $19 \%$ & 1.58 & $25 \%$ & 2.18 & $19 \%$ & 1.47 & $24 \%$ \\
\hline \multicolumn{9}{|c|}{ Erosion costs } \\
\hline $80 \%$ & 1.46 & $-0.8 \%$ & 1.25 & $-0.7 \%$ & 1.82 & $-0.2 \%$ & 1.18 & $-0.1 \%$ \\
\hline $90 \%$ & 1.47 & $-0.4 \%$ & 1.26 & $-0.3 \%$ & 1.82 & $-0.1 \%$ & 1.18 & $-0.1 \%$ \\
\hline $110 \%$ & 1.48 & $0.4 \%$ & 1.26 & $0.3 \%$ & 1.83 & $0.1 \%$ & 1.18 & $0.1 \%$ \\
\hline $120 \%$ & 1.48 & $0.8 \%$ & 1.27 & $0.7 \%$ & 1.83 & $0.2 \%$ & 1.18 & $0.1 \%$ \\
\hline $150 \%$ & 1.50 & $2.0 \%$ & 1.28 & $1.7 \%$ & 1.83 & $0.5 \%$ & 1.19 & $0.3 \%$ \\
\hline
\end{tabular}

\section{Conclusion}

Soils are remarkable systems and their biodiversity plays an important role in providing ecosystem services. At its most basic, "terroir" is also a relevant quality factor for wine strongly related to the land and climate where the grapes are grown. Protection of this valuable source should be of high priority to winegrowers. Cover crops reduce soil erosion and provide a series of other ecosystem services, on-site as well as off-site, which makes them an ideal management practice from an environmental point of view. 
But the results show that CC tend to increase production costs, mainly due to higher labour needs. Especially for family-owned vineyards labour is a constraining factor. Winegrowers in Montilla-Moriles already work on the edge of profitability, if only variable costs are included. In this region grapes are sold for a low price of $0.30 € / \mathrm{kg}$. It is plausible, that there are more urgent concerns than the long-term protection of terroir and biodiversity. In Austria we have a different situation. Here winegrowers realize better output prices $(0.90 € / \mathrm{kg})$, and are generally better positioned on the market than their Spanish peers, since they mostly generate added value through the production and marketing of their own wine. CC are even used out of marketing reasons. The results demonstrate that not only the production costs are relevant for management decisions of vineries but also the retail price.

Nevertheless, if all on- and off-site costs are considered, CC are cost-effective in both regions. This is even without the valuation of non-marketed ecosystem services such as cultural and aesthetic aspects.

Even though in the long-term winegrowers benefit from a stable wine quality based on the saved terroir, their management needs to change in the short term. Yet, more restrictive environmental regulations could drive winegrowers out of business due to their already difficult financial situation. If policy wants to prevent this situation while further improve biodiversity, supporting CC through regional adjusted AEMs should be continued. Since the current AEMs only cover the direct management costs of CC, an increase of payments which reward further saved social costs could be discussed.

European winegrowers need different levels of encouragement and reimbursement for their short-term costs and their provision of external ecosystem services. However, encouraging increasing output prices can have an effect on the implementation of sustainable practices as well.

\section{Acknowledgement}

This work contributes to the VineDivers Project (01LC1401A) and the authors are grateful for the financial support through the 2013/14 BiodivERsA/FACCE-JPI joint call for research proposals and the Federal Ministry of Education and Research.

We like to especially thank our research partners and the winegrowers in Austria and Spain who helped with this study and provided relevant data. 


\section{How cover crops and soil biota could improve wine prices. A competitive analysis of French winegrowers}

Elke Plaas, Rebekka Schütte, Morgane Hervé, Annegret Nicolai

This paper has been submitted to

Applied Soil Ecology 


\section{Abstract}

France is one of the world's leading wine producers and exporters. Winemaking has long traditions in France and wine is a valuable export good. The vinicultural sector provides jobs and economic revenue and many studies describe the importance for the French economy. But, intense wine production in the context of international competition has led to excessive negative ecological effects on the agroecosystem and on soil biodiversity. These effects, and measures to mitigate them, are still poorly explored.

Cover crops can reduce soil erosion and potentially enhance soil biodiversity. In the French region Loire valley, we analysed the effects of cover crops on organic matter content and on soil biodiversity. We show that cover crops increase organic matter as well as plant, earthworm and gastropod diversity which play all major roles in the ecosystem. Using an additional questionnaire we gain insights about the consumers' willingness to pay for environmentally friendly produced wine. These findings are incorporated in a business assessment of the competitiveness of French wineries from the Layon region with three scenarios (bare soil, cover crops, cover crops \& local promotion) using the Policy Analysis Matrix (PAM).

\section{Keywords}

Biodiversity, viniculture, Policy Analysis Matrix, herbicides, competitiveness, ecosystem services

\section{Authorship Declaration}

Important contribution: The personal contribution to the paper is above $30 \%$. 


\section{Introduction}

Within the European food sector, wine is a main export good and half of the worldwide vineyards are planted in the EU (EUROPEAN COMMISSION, 2016A). European vineyards are smaller than in other wine producing countries and are cultivated more labour-intensively (CARTER, 2012). Nevertheless, this economic disadvantage can be a benefit for shaping landscapes and for providing biodiversity which fulfils important functions for viniculture. The fragmentation of Europe's viniculture displays through its various regions of protected designation of origin (PDO) and protected geographical indication (PGI) according to the European Union definition. In France generally the national declaration designation of geographical origin (DGO) is used.

Each of these areas is characterised by its vine varieties, soil, climate and management practices, but also has to cope with various pests and diseases. Viniculture is among the most pesticide-dependent land use types in Europe. About $20 \%$ of all applied pesticides are used in vineyards, which occupy slightly less than $3 \%$ of the total agricultural area (OJEDA ET AL., 2017). In France, viniculture is ranked third in terms of number of unit doses per hectare (URRUTY ET AL., 2016) with 13-16 treatments per year on average (RUSCH ET AL., 2017). Accordingly, the use of pesticides is an important part of vintners' production costs.

Different types of tillage and spraying herbicides are common in vineyards to decrease competition between weeds and vine which results in bare soil on $51 \%$ of the winegrowing area in France (AMBIAUD, 2012). $80 \%$ of the bare soil is obtained by herbicide treatments, while the remaining $20 \%$ are established by tillage. In the Loire Valley the herbicide-treated bare soil area reaches $92 \%$ (AGRESTE, 2010). Only $49 \%$ of French vineyards are cover cropped of which only $39 \%$ have permanent vegetation cover (AMBIAUD, 2012). However, there are strong discrepancies among regions and the cover cropped areas vary between more than $85 \%$ and less than $30 \%$.

Herbicides have been proven to harm biodiversity, such as plant diversity (SANGUANKEO \& LEÓN, 2011), earthworm activity (GAUPP-BERGHAUSEN ET AL., 2015), arthropod abundance (BEGUM ET AL., 2006), collembolan abundance (RENAUD ET AL., 2004), microbial activity (MARTINS ET AL., 2013), and fungi benefiting plants (ZALLER ET AL., 2014), but also groundwater quality, and human health (LOUCHART ET AL., 2001). 
Therefore, the reduction of herbicides has the potential to benefit environment and human life. Winegrowers may benefit from maintaining a permanent vegetation cover through its various positive effects. These include erosion mitigation (BLAVET ET AL., 2009), buffering of soil nitrogen availability (PÉREZ-ÁLVAREZ ET AL., 2015), increasing of soil organic matter content (STEENWERTH \& BELINA, 2008), regulating water use (MONTEIRO \& LOPES, 2007), influencing soil temperature and vineyard microclimate (FOURIE \& FREITAG, 2010), controlling vine vigour and enhancing grape quality (GIESE ET AL., 2014). Among these processes, organic matter degradation is especially important for soil quality and functions (BENCKISER, 1997). Litter degrading soil organisms such as earthworms and gastropods can affect vineyard productivity by participating in carbon and nutrient cycles and food web interactions (BARRIOS, 2007). The various values of biodiversity and the need for protecting those, is widely accepted (MACE, 2014). In the EU a biodiversity strategy was installed which targets the development of a sustainable economy and an improvement of the biodiversity status (EUROPEAN COMMISSION, 2011). With a focus on belowground biodiversity, the utilisation of cover crops (CC) can contribute to this goal. Some taxa amongst soil biota play key roles in regulating soil processes. In general, soil biota influences soil processes in interaction with soil conditions as well as soil management practices of the farmers (or vintners) such as tillage or crop rotations (PLAAS ET AL., 2019). There is a strong connection between soil quality and food provision which is also declared in the Sustainable Development Goals of the United Nations (UN GENERAL ASSEMBLY, 2015). By 2030 sustainable food production systems should be insured by implementing resilient agriculture practices that improve soil quality.

Additionally, greened vineyards contribute to landscape aesthetics and hence to touristic attractiveness. This may be especially beneficial for winegrowers who sell their wine to visitors directly in the cellar (HERVÉ ET AL., 2018). These vintners are able to set their own wine prices and do not have to sell their grapes, juices or wines for lower prices to cooperatives or wine trading companies. According to TRAVERSAC ET AL. (2011), in France nearly 50 \% of grapes are harvested by wine producers who also crush their own fruit. They sell the on-farm produced wine as bulk, bottles or 
containers to trading companies, retailers, and caterers or directly to the consumer. The product is therefore exclusively bound to the vineyard and the vintner.

Following the outlined potential benefits (provided by biodiversity and direct marketing), our hypothesis is that winegrowers in a French wine region such as Coteaux du Layon in the Loire Valley could avoid herbicides and use CC instead, and still be competitive. The economic benefit of long term application of CC could be provided by increased soil biota through enhancing soil functioning and vineyard productivity as well as by touristic attractiveness allowing higher wine prices if wine was sold directly.

Therefore, we tested three different CC scenarios and compared them to a conventional herbicide scenario using a Policy Analysis Matrix (PAM). In two simple CC scenarios, we verified increased soil organic matter and soil biodiversity (plants, earthworms, and gastropods) which could also be beneficial for grape production (BARRIOS, 2007). Subsequently we tested the willingness to pay (WTP) more for environmentally friendly produced wine in cellars with visitors and based our third CC scenario on direct marketing with higher wine prices.

\section{Methodology}

\section{Study region}

The DGO 'Coteaux du Layon' represents a sweet white wine produced from the local vine variety Chenin blanc. This region is situated in the department Maine-et-Loire within the Loire valley in the northwest of France (Figure 7-1). DGO rules address a great variety of practices from the establishment of the vineyard (e.g., grass strips surrounding vineyards), grape production (e.g., limited yields and late hand harvesting) to the vinification processes. Yet, soil management is not addressed by this regulation and vintners are free to choose the practices they prefer (CODE DE LA CONSOMMATION ARTICLE L431-1, N.D.; CODE RURAL ET DE LA PÊCHE MARITIME, N.D.).

Within the DGO territory, 300 winegrowers cultivate vines on 1435 ha and produce $40957 \mathrm{hl}$ of the wine 'Coteaux du Layon'. At a minor share other wine types based on various vine varieties are produced as well. In this DGO, roughly half of the winegrowers carry the 'Vigneron Indépendant' (Independent Winegrowers) label and produce and sell their wine directly in the cellar (HERVÉ ET AL., 2018). Part of their 
grape production is intended for a marketing strategy of full vertical integration, i.e. from grape growing through to selling of wines with their own brand (TRAVERSAC ET AL., 2011). Most of the 'Independent Winegrowers' also develop eno-touristic activities, such as wine tastings and vineyard hikes to attract visitors as potential wine consumers. Their strategy is also supported by local tourism institutions through organized activities and by politics through the creation of the "Vineyards Touristic Circuit". Overall, in this DGO a general dynamic of developing eno-tourism and enotouristic events, such as wine markets, vineyard hiking, biking festival and open cellars, can be observed.

Figure 7-1: The wine growing area DGO 'Coteaux du Layon' in the Loire Valley

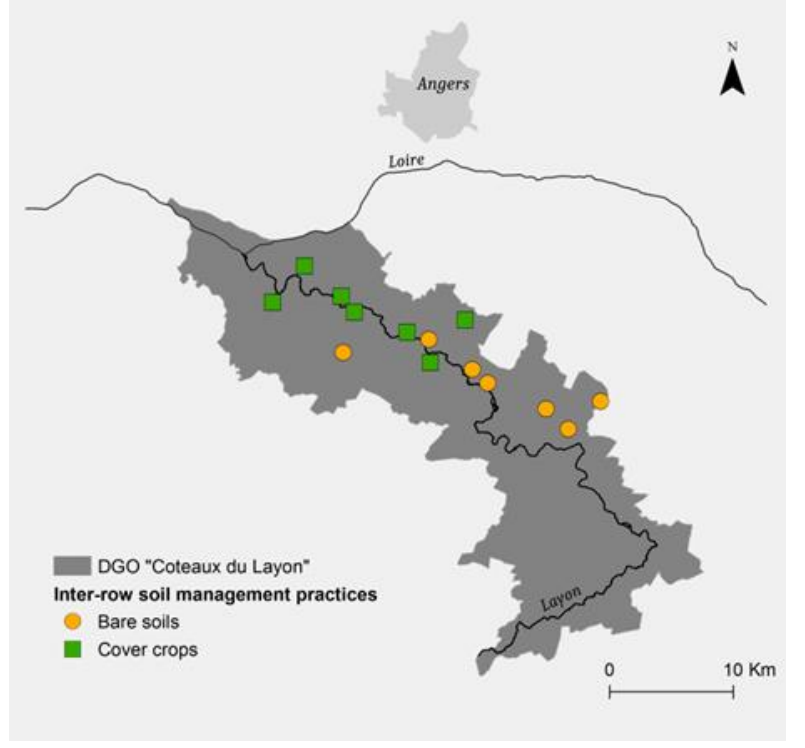

France, near the town Angers

Studied vineyards with bare soil obtained through 3-4 herbicide applications (yellow circles, $N=7$ ) and with cover crops (green squares, $N=7)$ in the inter-rows.

\section{Soil organic matter and soil biodiversity}

In order to determine whether cover crops in vineyard inter-rows have an impact on soil organic matter (OM) content as well as on diversity of plants (PL), earthworms (EW) and gastropods (GA) we compared vineyards with bare soil $\left(\mathrm{Nom}=\mathrm{N}_{\mathrm{PL}}=\mathrm{NeW}_{\mathrm{EW}}=7, \mathrm{~N}_{\mathrm{GA}}=4\right)$ and with permanent cover crop management $\left(\mathrm{Nom}_{\mathrm{N}}=\mathrm{N}_{\mathrm{PL}}=\mathrm{N}_{\mathrm{EW}}=7, \mathrm{~N}_{\mathrm{GA}}=5\right)$. The vineyards were distributed across the DGO area to capture the heterogeneity of soil and bedrock formation in the area (Figure 7-1). In the sampling year 2016, herbicides were applied three to four times to obtain bare soil, while spontaneously growing cover crops were mowed three to four times and herbicides were only used in the weed and grass-free strips under the vines instead of the whole inter-row. 
In order to determine OM content (i.e. organic Carbone content) one soil sample per vineyard was taken $(500 \mathrm{~g})$ in March, stored at $-25^{\circ} \mathrm{C}$ and sent to the INRA Laboratory for Soil Analyses Arras (dry combustion, NF ISO 10694). PL and EW species richness were determined in June on 4 plots $(1 \mathrm{x} 1 \mathrm{~m})$ and in March on four soil blocks ( $25 \mathrm{x} 25 \mathrm{x}$ $25 \mathrm{~cm})$, respectively, in one inter-row of each vineyard following the protocol of (BUCHHOLZ ET AL., 2017). GA species richness was determined in May on one topsoil block $(25 \times 25 \times 2 \mathrm{~cm})$ and by a random time-constraint search of two persons per ten minutes in one inter-row per vineyard. The soil block was sieved and each individual was identified to species. OM content and species richness were compared between the two soil management practices using the non-parametric Mann-Whitney test.

\section{Willingness to pay (WTP)}

In order to test the WTP for environmentally friendly produced wine, we conducted a questionnaire, which sampled the percentage consumers are willing to pay more for environmentally produced 'Coteaux du Layon' wine (with CC versus bare soil), using the current mean price of $10 € /$ bottle as a baseline. The socio-demographic part in the questionnaire was used to investigate the respondents profile following the method of (HERVÉ ET AL., 2018).

Visitors of the region were profiled according to their touristic interest for the studied region: wine ('Wine Purchase' profile), visit of vineyards and cellar ('Eno-tourism' profile), nature activities ('Green Tourist' profile), historical buildings and places ('Historical Heritage' profile) and conjunction of different types of interest e.g. vineyards and nature ('Terroir' profile). During spring/summer 2016, the questionnaire was presented, mainly in person, to 119 visitors in different parts of the 'Coteaux du Layon' during touristic events, such as vineyard visits, open cellars, hike and taste days, and regional festivals, as well as on campsites and in tourist information offices. Additionally, an electronic version of the questionnaire was published by tourist information offices and the 'Independent Winegrowers'. Fisher exact tests were performed to test the existence of a relationship between tourist profiles and their WTP for an environmentally-friendly wine that is locally produced. 


\section{Policy Analysis Matrix (PAM)}

To analyse the competitiveness of wine production and to show the economic effects of different inter-row management, we used the Policy Analysis Matrix (PAM) (MONKE \& PEARSON, 1989). The PAM is a simplified partial equilibrium model that assumes the Leontief production function. Due to its static characteristics we cannot estimate future scenarios of wine production in 10 or 20 years. But it is a simple and useful tool to compare different production systems, regions and scenarios in consideration of all real production costs. Therefore, it is often used to analyse competitiveness of agriculture production systems in transition countries (LAKEMEYER, 2007).

With the PAM we compare private profitability before and after price changes. The results indicate the influence of these changes on the competitiveness in market prices. The model is based on disaggregated data that is classified into four categories: „tradable inputs, domestic factors, transfers (like taxes or subsidies that are set aside in the social evaluations), and non-tradable inputs (which have to be further disaggregated so that all the costs will be classified under tradable inputs, domestic factors and transfers)“ (ABDUL \& VON CRAMON-TAUBADEL, 2015).

The private prices for inputs and outputs in the first column (Table 7-1) are farm gate prices and are mainly obtained from farm budgets. The revenue and cost categories in social prices are estimations based on world prices (FAO, N.D.). We use national and regional statistics about import prices for final goods (e.g. grapes or bottled and bulk wine) and export prices for commodities that are used for the production process (e.g. plant protection, technical equipment, fertilizer) to estimate efficiency prices for input factors.

For domestic factors of production (land, labour and capital) we calculate the social (efficiency) prices by application of the social opportunity cost principle (PEARSON ET AL., 2003). The domestic factors are characterized by the fact that they are not tradable and therefore world prices are not available. We estimate the social opportunity costs by observing the rural factor markets for labour and capital. The land market price is also available from market observation. However, ZYL ET AL. (1994) argue that nonfarm factors such as policy distortions may get capitalized into market values. Hence, land values tend not to reflect the true economic value to the society. That is why 
MONKE \& PEARSON (1989) recommend the use of rental value instead of market value, which reflects the opportunity cost to use land. Based on this recommendation we use rental value for land.

Table 7-1: The Policy Analysis Matrix

Revenues

Private Prices $\quad A=p_{i}^{p} \quad B=\sum_{j=1}^{k} a_{j i} p_{j}^{p} \quad C=\sum_{j=k+1}^{n} a_{k i} p_{k}^{p} \quad D=\pi_{i}^{p}=A-B-C$

\begin{tabular}{|c|c|c|c|c|}
\hline Social Prices & $E=p_{i}^{S}$ & $F=\sum^{k} a_{j i} p_{j}^{s}$ & $G=\sum^{n} a_{k_{i}} p_{k}^{s}$ & $H=\pi_{i}^{S}=E-F-G$ \\
\hline Divergences & $I=A-E$ & $I=B-F$ & $K=C-G$ & $I-D-H-I-I-K$ \\
\hline
\end{tabular}

Source: Monke \& Pearson (1989: 11)

Notes: the subscript $i$ refers to outputs and the subscript $j$ to inputs;

$a_{j i}$ for $(j=1$ to $k$ ) are technical coefficients for traded inputs in the production of $i$;

aji for ( $j=k+1$ to $n$ ) are technical coefficients for domestic inputs in the production of $i$;

$P_{i}{ }^{*}$ is the price of output $i$, evaluated privately $\left(" *^{\prime \prime}=p\right)$ or socially $\left(" *^{\prime \prime}=s\right)$;

$P_{j}{ }^{*}$ is the price of traded input $j$, evaluated privately $\left(" *^{\prime \prime}=p\right)$ or socially $\left(" *^{\prime \prime}=s\right)$;

$V_{j}{ }^{*}$ is the price of domestic input $j$, evaluated privately $\left(" *^{\prime \prime}=p\right)$ or socially $\left(" *^{\prime \prime}=s\right)$;

I measures output transfers; I measures input transfers;

$K$ measures factor transfers; isEP: $D(=A-B-C)$ measures net private profits;

$H(=E-F-G)$ measures net social profits; and

$L$ measures net transfers.

The resulting PAM provides indicators and ratios such as the Private Cost Ratio (PCR) and the Domestic Resource Cost Ratio (DRC). Calculating and comparing the DRC $(\mathrm{G} /(\mathrm{E}-\mathrm{F}))$ provides a closer focus on the policy and market analysis of the wine producing countries. If $0<\mathrm{DRC}<1$ the coefficient indicates comparative advantage: the social cost of domestic resources used is smaller than the corresponding social gain (value added). The opposite is true if DRC $>1$. In case of a DRC that is smaller than 0 , the denominator must be negative. In this case revenue does not even suffice to cover tradable input costs. In this case, production of the good in question is clearly not competitive (NIVIEVSKYI \& VON CRAMON-TAUBADEL, 2009). As MASTERS \& WiNTERNELSON (1995) indicate, the DRC is influenced by the amount of domestic factors which are used by a commodity system. In usual, DRC results should be interpreted with caution because a weakness of the DRC method is the use of average or 'typical' 
data for a sector or industry. For this reason, the statistical data we used was complemented with regional data obtained from five semi-directional interviews with winegrowers and a regional focus group (SCHÜTTE \& BERGMANN, 2019). In addition to the discussion, winegrowers filled a questionnaire indicating the share of their costs among other information on their business. Grey literature was the main source for secondary data e.g. official statistics provided by regional institutions and the EU. As key sources for secondary budget information in France we used data from BARNIER, (2012) and CHAMBre D' AGRICUlTURE DE L'HÉRAult $(2013,2019)$.

Based on the various types of winegrowers there are different prices for traded grapes (for wine production), traded bulk wine (for brand) and bottled wine (for direct marketing). In the Loire Valley, the price differences per litre of wine are huge, ranging from 0.50 EUR up to an average price of 6.10 EUR (FRANCEAGRIMER, 2015).

In this study, we compare two CC scenarios with a basic scenario of using herbicides. All three scenarios are calculated for one hectare of privately owned vineyard in France, Loire Valley region. We used average primary as well as secondary data, adjusted by inflation for the year 2016 .

(1) In the basic scenario, a conventional management system with herbicide use and private prices based on a medium production with a low bulk wine price (retailer price of $0.80 \mathrm{EUR} / \mathrm{l}$ ) is assumed.

(2) In the cover crop scenario the use of herbicides was reduced and winegrowers benefit from maintaining a permanent vegetation cover through various positive effects on their production system. Labour costs for spraying herbicides were replaced by costs for mowing in the inter-rows.

(3) In the cover crops with direct marketing scenario we analysed the hypothetical situation that vintners, who are adopting cover crops, focus their marketing strategy on direct selling of bottled wine. We assume that vintners may benefit of higher prices through direct marketing.

\section{Results}

The use of CC significantly increases the organic matter content (Figure 7-3a), MannWhitney, $\mathrm{W}=7, \mathrm{df}=13, \mathrm{p}=0.026$ ) and species richness of plants (Figure 7-3b), MannWhitney, $\mathrm{W}=0, \mathrm{df}=13, \mathrm{p}=0.002$ ), of earthworms (Figure 7-3c), Mann-Whitney, $\mathrm{W}=6$, 
$\mathrm{df}=13, \mathrm{p}=0.020$ ), and of gastropods (Figure 7-3d), Mann-Whitney, $\mathrm{W}=20, \mathrm{df}=8, \mathrm{p}=0.016$ ). The positive effect of the use of CC for soil content in the vineyards in Loire Valley is clearly indicated.

\section{Figure 7-2: Abundance of soil biota under bare soil and CC management}
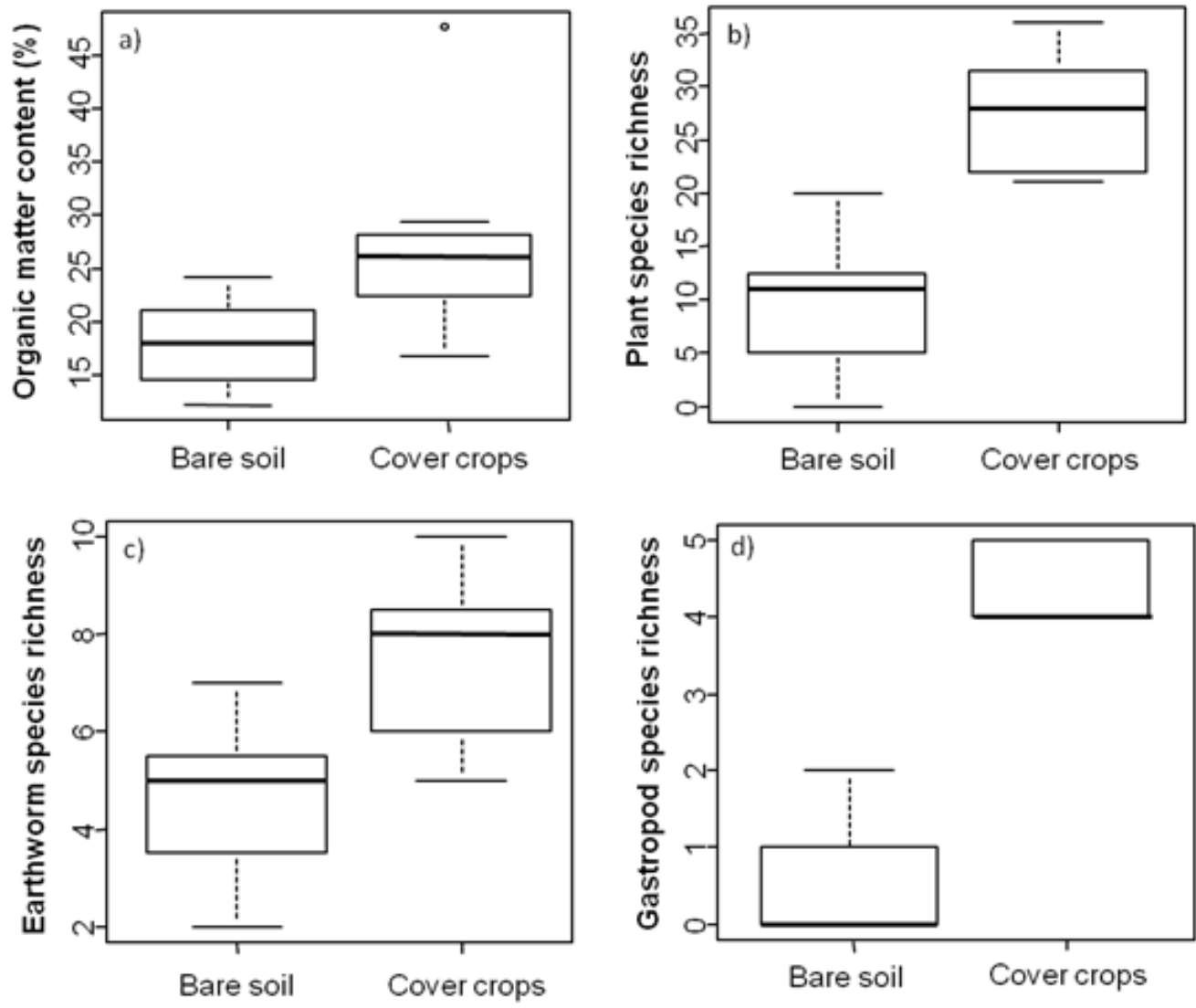

Caption: Organic matter content in the soil (a), plant species richness (b), earthworm species richness (c), and gastropod species richness in vine fields with permanent cover crops and without (bare soil obtained with herbicides). Boxes represent the quartiles with the median as line within the box. Error bars indicate deciles. There is a significant difference between bare soil and cover crops for all four measured parameters (Mann-Whitney, $p<0.05$ ).

According to our questionnaire, most of the visitors were interested in nature and in the terroir which shows that the DGO "Coteaux du Layon" is attracting tourists because of the relationship between wine quality and natural conditions (HERVÉ ET AL., 2018).

Overall, nearly $85 \%$ of the visitors in the DGO stated they are willing to pay more for 'environmentally friendly produced' wine regarding soil management practices. This was observable within each tourist profile (Fisher Exact Test, N=118, df=4, p>0.05). However, the mark-up which visitors are willing to pay differed between profiles (Table 7-2), Fisher Exact Test, $\mathrm{N}=117, \mathrm{df}=12, \mathrm{p}<0.05)$. While green and terroir tourists 
(representing $73 \%$ of all tourists) showed an equal interest in paying $5 \%$ or less, $10 \%$ or $20 \%$ more, eno-tourists were clearly willing to pay $20 \%$ more, and tourists interested in historical heritage stated a WTP of $10 \%$ more.

Table 7-2: Additional WTP for environmental friendly produced wine

\begin{tabular}{lccccccc} 
& $\begin{array}{c}\text { Not } \\
\text { willing or } \\
\text { up to } \mathbf{5 \%}\end{array}$ & $\begin{array}{c}\text { Willing up } \\
\text { to } \mathbf{1 0 \%} \\
\text { more }\end{array}$ & $\begin{array}{c}\text { Willing up } \\
\text { to } \mathbf{2 0 \%} \\
\text { more }\end{array}$ & $\begin{array}{c}\text { Willing up } \\
\text { to more } \\
\text { than 20\% }\end{array}$ & $\begin{array}{c}\text { Total of } \\
\text { tourists }\end{array}$ & \\
\hline Eno tourism & 1 & 0 & 10 & 3 & 14 & $\mathrm{a}$ \\
Green tourism & 12 & 10 & 10 & 4 & 36 & $\mathrm{bc}$ \\
Historical Heritage & 0 & 6 & 3 & 2 & 11 & $\mathrm{~b}$ \\
Terroir & 12 & 14 & 16 & 9 & 51 & $\mathrm{bc}$ \\
Wine purchase & 2 & 0 & 3 & 0 & 5 & $\mathrm{ac}$
\end{tabular}

Note: Distribution of answers among tourists according to their touristic interests. Letters in the last column denote significant differences following Fisher's post-hoc test $(p<0.05)$.

According to our questionnaire, most of these tourists are interested in nature and in the terroir which shows that this DGO is attracting tourists for the relationship between wine quality and natural conditions. Natural conditions included in the terroir concept, but also vineyard management practices at the landscape scale, may be related to wine quality.

In Table 7-3 the PAM scenarios are presented. The basic scenario shows that vintners in the DGO generate a profit which is lower than in other wine producing regions in the world (social prices). However, in all scenarios, the DRCs are smaller than one. This indicates that producing wine in this region in France is competitive.

Table 7-3: Coefficients from the PAM scenarios in 'Coteaux du Layon'

\begin{tabular}{lccc} 
& $\begin{array}{c}(\mathbf{1}) \\
\text { Basic }\end{array}$ & $\begin{array}{c}\mathbf{( 2 )} \\
\mathbf{C C}\end{array}$ & $\begin{array}{c}\text { (3) CC and } \\
\text { Marketing } \\
\text { scenario }\end{array}$ \\
\hline scenario & scenario & 1144 & 1144 \\
Factor costs $€ /$ ha (private, without land) & 5230 & 5230 & 5230 \\
Output price $€ /$ kg (private) & 0.80 & 0.80 & 4.00 \\
Net Private profit $€ /$ ha & 2280 & 2267 & 28763 \\
\hline DRC & 0.54 & 0.54 & 0.10 \\
\hline
\end{tabular}

Own calculations based on data from focus groups and semi-directed interviews SCHÜTTE E BERGMANN, (2019) as well as on data from (BARNIER, 2012; CHAMBRE D'AGRICULTURE DE L'HERAULT, 2013, 2019; FAO, N.D.; FRANCEAGRIMER, 2015; KTBL, 2018)

Compared to the first scenario, competitiveness in the second scenario was only slightly affected by the use of CC. Herbicide costs are substituted by labour costs for more time intensive mechanical work in the vineyard. Some of the vintners pointed out 
that they would need other machinery for sowing and mowing the $\mathrm{CC}$, which they do not necessarily own. This might reduce the profitability slightly. To decrease competition between inter-row vegetation and vines during the summer period and to prevent the seeding of weeds it is useful to mow CC in early summer.

The cover crop and marketing scenario assumes that the WTP for sustainably produced wine from "green covered" vineyards is higher than for conventional produced wine and can lead to significantly higher sales prices. The production costs for grapevines are the same like in scenario 2, but the output price is apparently higher (4 EUR/l). The DRC therefore shows a strong increase in profitability.

\section{Discussion and Conclusion}

Our field study has validated that CC have a positive effect on the ecosystem and we were able to illuminate these effects in more detail for organic matter content in soil, plant, earthworm and gastropod species richness. Organic matter is commonly admitted as a soil quality indicator (in 46 studies worldwide (BÜNEMANN ET AL., 2016)). Organic matter once degraded and mineralized by soil biota, will provide nutrients for plants and hence increase productivity (BARRIOS, 2007). We also showed that litter and organic matter degrading organisms, such as earthworms and litter-dwelling gastropods are more diverse when CC are present. The decomposition activity and efficiency of these groups strongly depend on plant diversity (MILCU ET AL., 2006) and on within-taxon diversity allowing interactions between species within food webs (BRUSSAARD, 1998). These specific effects can influence the profitability of a winegrowing business in the long-term through increasing soil fertility (i.e. availability of nutrients for plants (BÜNEMANN ET AL., 2016)).

In the short-term, CC can result in an increasing profit, as consumers revealed a higher WTP for wine from greened vineyards. In the study of HERVÉ ET AL. (2018), CC were the third most indicated motivation to buy wine in Coteaux du Layon (after wine and craftwork). The authors also showed that this is probably linked to some aesthetic contribution to the landscape. Landscape aesthetics are cultural ecosystem services and are underrepresented in environmental economics even though they are able to influence management decisions of landowners (PLIENINGER ET AL., 2015). These 
environmentally friendly changes in soil management are therefore increasing the social and ecological status of vineyards.

The reduction of herbicide costs will be counteracted by more working hours and machinery usage which are needed for maintaining permanent spontaneous vegetation or cultivating $\mathrm{CC}$ in the inter-row. Hence, inter-row vegetation management would lead to an increase in production costs. For winegrowers the need of more labour for $\mathrm{CC}$ is an important factor especially since we can find many family businesses that do not have additional work forces (SCHÜTTE \& BERGMANN, 2019). And grape production is already very labour intensive (TRAVERSAC ET AL., 2011) with all those activities like vine training, pruning, thinning and finally the hand harvest which is a symbol for wine quality (LAFERTÉ, 2003). Data from the CHAMBre D'AGRICULTURE DE L'HERAULT (2013) confirmed a high cost share for labour in viniculture in general. However, private profitability is achieved in all scenarios and the DRC stayed smaller than 1 which indicates that the production of grapes in Coteaux du Layon with CC is competitive.

Winegrowers can even achieve a higher profitability with CC than in the basic scenario if they develop eno-tourism and local market opportunities and absorb the higher WTP of consumers.

The three PAM scenarios demonstrate that the competitiveness of winegrowers is not weakened exceedingly by the use of CC. The participants of focus groups pointed out, that the use of CC leads to a higher risk of water scarcity in hot and dry summers (SCHÜTTE \& BERGMANN, 2019). With climate warming and droughts being more frequent (DELLA-MARTA ET AL., 2007), winegrowers consider the risk associated to hot and dry summers, which may have negative effects on the grapes (PEREGRINA ET AL., 2012). They wish for the possibility to at least till the inter-rows to mitigate water competition. Although, no significant competitive effects of inter-row vegetation cover were observed in vineyards under oceanic climates (STEENWERTH ET AL., 2013), such as most parts of France including the Loire Valley. Vintners prefer a flexible system where they have the possibility to till the soil in the inter-rows in case of droughts. This wish for flexibility should be taken into account in national or European policy. 
Our results are based on aggregated data from vineyards that most certainly disguise possible variation and the underlying distribution of competitiveness across a set of heterogeneous vintners. This can have far-reaching implications for policy conclusions based on our PAM results. Therefore, only careful conclusions based on average DRC are drawn.

The question how to integrate a perceived or real risk into the economic policy model still remains. The competitive effect of CC is poorly studied and rarely experimented by winegrowers who tend to apply a precautionary principle, i.e. taking preventive action in the face of uncertainty (KRIEBEL D ET AL., 2001). This has implications for policy regarding the adaptability of laws to changing conditions in the environment (ARNOLD \& GUNDERSON, 2013). Gaining sustainability is an important element for vintners who work since generations in the vineyards and "for practitioners in the wine industry, priority number one is leaving the land in better shape for the next generation" (GILINSKY ET AL., 2016).

\section{Perspectives}

Our results show that viniculture in Layon is competitive in the worldwide market even if winegrowers permanently use CC. Biodiversity enrichment in viniculture in the DGO 'Coteaux du Layon' may generate synergies between economic and ecological functions. Policy would be most effective if leaving flexibility of action and management decisions to winegrowers to face possible risks related to climate warming. These results are specific for one wine growing region in France where a bottom-up dynamic of eno-tourism development can be observed and economically favours the adoption of environmentally friendly vineyard management. In connection with the BiodivERsa VineDivers project, further research will focus on identifying diversified strategies in using cover crops adapted to other European wine producing countries or regions. 


\section{Acknowledgments}

This research is part of the BiodivERsA project VineDivers (www.vinedivers.eu) and was funded through the 2013-2014 BiodivERsA/FACCE-JPI joint call for research proposals, with the national funders: Austrian Science Fund (FWF, grant number I 2044-B25), French National Research Agency (ANR), Spanish Ministry of Economy and Competitiveness (MINECO), Romanian Executive Agency for Higher Education, Research, Development and Innovation Funding (UEFISCDI) and Federal Ministry of Education and Research (BMBF/Germany). We are grateful to the winegrowers in the study region of DGO 'Coteaux du Layon' who provided information on vineyard management and granted access to study their vineyards. 


\section{Discussion and Conclusion}

Europe's vinicultural sector is of economic, environmental as well as cultural relevance, and is immensely divers in its small-scale structures. The stable environment of permanent crops offers many possibilities for ES, but is often managed intensively. These traditional managed vineyards, with bare soil, might be beautiful for the human eye, yet affect biodiversity negatively and lead to immense soil erosion. Accordingly, some of the most degraded soils of Europe can be found in wine areas (PANAGOS ET AL., 2015).

To comply with the declared goal of the EU, for a sustainable agriculture and the recreation of biodiversity (EUROPEAN COMMISSION, 2011), vineyard management has to change permanently.

Maintaining vegetation in the inter-rows of vineyards has been proven to be a valuable method to increase soil biodiversity and support overall ES (WINTER ET AL., 2018). Although, CC can indeed have economic benefits for winegrowers and control the vigour of vines (MONTEIRO ET AL., 2008), support pest control (BERNDT ET AL., 2006), and serve as a marketing tool (SCHÜTTE \& BERGMANN, 2019), this management is not evenly utilised in Europe's vineyards. Economic constraints appear to be a main barrier. If the cultivation of vegetation cover is not adapted to the climatic conditions, there is a risk of reduced yields as CC compete with the vines for water and nutrients (ROSA ET AL., 2013; MEDRANO ET AL., 2015). The risk is therefore higher in regions with low precipitation and longer summer droughts.

The objectives of this work were to attain better knowledge about

- the backgrounds of management decisions concerning sustainability as well as soil biodiversity and

- the trade-offs between biodiversity and the economic situation of winegrowers. A 'one fits all' political solution for sustainable viniculture will not meet the demands of all different MS and wine regions. Therefore, it is particular important to gather knowledge also in smaller wine regions, for a better overall picture. For this thesis, three wine regions in Austria, France and Spain were investigated.

Based on a semi-structured questioning route, a focus group discussion with winegrowers was carried out in each research region, and evaluated with the content 
analysis according to MAYRING (2015). In addition to this qualitative approach, the practical knowledge of the participants was used to underpin the competitive analysis with the PAM (MONKE \& PEARSON, 1989).

\section{Backgrounds of management decisions}

The results of the qualitative studies are presented in Chapter 4 and 5. It became clear that, despite all differences, winegrowers across Europe have similar concerns. They relate first and foremost to economic efficiency of their business, but also to their freedom as self-employed operators. More restrictive environmental policies are rejected, and the participants are tired of an increasing amount of bureaucratic burdens. Alongside economic reasons, the personal attitude towards environment, and the level of knowledge influence management choices as well, which also has been pointed out by LASTRA-BRAVO ET AL. (2015). Often the utilization of CC is prevented through traditional habits and the avoidance of risks.

If CC are established, winegrowers are convinced of the positive effects on the soil and the environment. The positive effect on landscape aesthetics is just as recognized as the value for direct marketing. Since the demand for eco-friendly and sustainably produced wine is increasing, the producers might have a chance to profit from the higher WTP of consumers (SCHÄUFELE \& HAMM, 2017).

Nonetheless, even participants who showed an eco-friendly mentality are aware of the risks CC entail. Across all focus groups it was confirmed that the competition between vines and CC is perceptible in practice. A risk for particularly dry years exists, and hence demands a flexible vegetation management.

Some participants, especially in France and Austria, revealed an attentive personal mentality towards sustainable management practices and an increasing biodiversity. They switched to CC even without financial incentives through policies. For them, AEMs are deadweight effects. And yet others use CC and do not apply for AEMs, to avoid additional paperwork and maintain flexibility. This indicates that AEMs might not completely fulfil their claim as an incentive for a more sustainable management.

Furthermore, AEM regulations restrict the necessary flexibility, as they often contain deadlines and therefore conflict with the weather dependency of viniculture. As a solution, the participants proposed timeframes instead of deadlines. Comparing 
winegrowers across the regions, it became clear that knowledge about coherences of vegetation cover and ES, biodiversity and production potential is of primary importance for producers and the adoption of new management methods.

\section{Trade-offs between biodiversity and economy}

For the competitive analysis, average budgets for grape production on one ha of vineyard on moderate slopes, and without irrigation have been constructed. These budgets were used to model different management scenarios, which were compared based on the SCB, PCB and DRC ratios.

In Chapter 6, three different inter-row management scenarios (CT, TCC and PCC) for Montilla-Moriles and Carnuntum are compared. On- and off-side costs of erosion, which are based on soil erosion rates, are integrated in the scenarios. On-side costs are considered as privately incurred costs, while off-side costs are born by society.

The study illustrates the tough economic situation for grape producers as both regions are not profitable under social prices $(\mathrm{SCB}<1)$; without even integrating erosion costs. The Austrian case reaches at least private profitability $(\mathrm{PCB}<1)$, but only due to subsidies.

The usage of CC in the inter-rows (scenarios TCC and PCC), usually leads to decreased erosion but also to moderate additional management costs. Although these are not covered by the savings in on-side costs, they are exceeded by the saved off-side costs. Hence, CC are a cost-effective management practice in both regions, if environmental costs are considered.

Although labour is often mentioned as a constraining factor for the implementation of $\mathrm{CC}$, the monetary labour increase is not significant. The physical availability of work might still be limiting, especially on family-operated holdings.

Overall, the integration of erosion costs does not lead to significant changes in the profitability of grape producers. This is due to the comparably low share of the estimated erosion costs. These costs could increase if further external costs such as CES are included.

In Chapter 7, PAM scenarios were used to illustrate the benefits of CC on the marketing aspect in Coteaux du Layon. The benefits of CC on ES were documented based on the abundance of soil biota and organic matter, under different management 
practices. A survey revealed a higher WTP for sustainably produced wine in different groups of visitors in the wine region. Therefore, PAM scenarios with varying output prices were constructed. These illustrate the opportunities CC offer winegrowers, not only on the subject of environment protection, but also for economy. Moreover, the scenarios illustrate the importance for winegrowers to participate in the value chain to achieve higher output prices.

\section{Limitations}

It is important to address the limitations of the used study design. Firstly, due to the small scale approach, it cannot be representative. Viniculture is shaped by heterogeneous farms and markets, and hence a broader quantitative approach will be needed for that claim. The number of participants in the focus group was unrepresentative and probably biased by already existing connections to other scientific projects as well as personal interest towards sustainable viniculture.

Despite these limitations, the qualitative content analysis of the focus groups revealed important results, which are in line with previous literature. Similar results have been shown by a choice experiment, which was conducted with olive growers (VILLANUEVA ET AL., 2015), as well as by studies regarding the adoption of AEMs (DEFRANCESCO ET AL., 2008; SATTLER \& NAGEL, 2010).

The scale problem also holds true for the PAM. Data was assembled on a typical case scenario, and has no entitlement for applicability to other vineyards or region. This is in regard to the absolute numbers and the considered cost categories. However, already under the simplifications of the model, the poor economic situation of smallscale grape growers is obvious. It is questionable, if those could cope with the internalisation of external costs, especially if the integration of environmental costs expands beyond erosion costs.

Another limitation is the static character of the PAM which leaves out dynamic production adaption. Nonetheless, the basic structure could easily be adapted for other study regions if adequate data is available.

Wine quality is connected with certain countries and regions as well as with grape varieties and the vintage (SCHÄUFELE \& HAMM, 2017). This explains the wide range of output prices, and the viability of many wine regions. It also complicates the 
development of comprehensive statements on the competitiveness of Europe's vinicultural sector. Further studies should therefore consider incorporating the costs of winemaking in the budgets, and simulate different output prices. This will probably further demonstrate the superiority of winemakers over grape growers.

\section{Concluding remarks}

The studied regions differ not only in climatic conditions, soil types and cultivated varieties. Differences can also be found in the overall management of vineyards, particularly in soil cultivation. A wide range, from bare soil to different types of TCC to PCC, can be observed. Herbicides are often the most economical solution to control vegetation, but can be replaced by mechanical weeding. The stated differences do not only occur between conventional and organic vineyards, but relate to other factors, too. In addition to the production side, the distribution channels vary as well. While winegrowers in Montilla-Moriles (ESP) mostly sell their grapes to cooperatives and therefore are price-takers, their peers in Carnuntum (AT) and Coteaux du Layon (FR) are regularly forward integrated and participate in the value chain. These winegrowers produce their own wine, are involved in direct marketing and gastronomy. Hence, direct sellers are in a better economic position, compared to grape producers. CC are more commonly used by direct sellers, which seems to be related to their economic position. They are enabled to offset risks and follow personal objectives. Knowledge is another important factor, which became clear in all three regions.

This strengthens the results of previous studies. The results of scientific work about soil biodiversity and effective erosion control needs to reach winegrowers, and must be easily accessible by the public. Investments should be made primarily in further training of winegrowers.

Admittedly, the subsidization of eco-friendly management is subject to criticism, based on the discussion about property rights and the 'polluter pays principle' (BROMLEY \& HODGE, 1990; CERIN, 2006). But if the economic situation and labour availability do not allow additional environmental services, promoting the use of CC in vineyards will remain difficult. The risk of production decrease should be minimized by developing regional adjusted CC management methods. Still, the implementation of new practices also requires some degree of innovation and willingness to take risks by vintners. On 
that account, risk compensation through subsidy payments or subsidized harvest insurance could be useful.

Attention should be paid to the ongoing structural change. For example, in MontillaMoriles the change from vineyards to olive or almond plantations is already noticeable. It remains questionable, if there are possibilities for $\mathrm{CC}$ to be accepted by a larger share of grape growers.

On the other hand, wine regions, where substantial higher output prices are achieved, exist (CEBUlla, 2018). Profits might be significantly higher than in the presented studies. This would strengthen the claim for a more compulsory policy design, as it would be economically feasible, for those businesses, to incorporate environmental costs. Thus, further research on this hypothesis should be considered.

Policies must be balanced between enough variability, so that farmers adopt the policies, and precise regulations, so that the environmental impact is ensured. But certainly changes are necessary, if irretrievably losses in biodiversity shall be averted (IPBES, 2019).

Inevitably, consumers have to pay for more biodiversity in vineyards; either through political induced subsidies or higher market prices. In the end, this leads to the question how much society is willing to pay for a healthy environment. 


\section{Literature}

Abdul, F., \& von Cramon-Taubadel, S., (2015) The Policy Analysis Matrix of Profitability and Competitiveness of Rice Farming in Malaysia. In: Milan, p. 23. Available from: https://ageconsearch.umn.edu/record/210872/ (accessed 7 May 2019).

ABDUL FATAH, F., (2017) Competitiveness and efficiency of rice production in Malaysia. Göttingen. Available from: http://ediss.unigoettingen.de/bitstream/handle/11858/00-1735-0000-002B-7D5A2/FINAL\%20THESIS\%20FAZLEEN.pdf?sequence $=1$.

AGRESTE (2010) Agreste. Available from: https://stats.agriculture.gouv.fr/disar/faces/report (accessed 11 July 2017).

AlCÁZAR, J.I.F., (2011) Costes de cultivo en viñedo. Cuaderno de campo (46): 4-13.

AlLIANCE ENVIRONMENT \& ThÜNEN INSTITUTE (EDS) (2017) Evaluation study of the payment for agricultural practices beneficial for the climate and the environment - Final Report. Luxembourg: Publications Office of the European Union. Available from: https://ec.europa.eu/agriculture/sites/agriculture/files/fullrep_en.pdf.

AMA (2015) ÖPUL 2015 Maßnahmenerläuterungsblatt - Erosionsschutz Obst, Wein, Hopfen. Available from: https://www.ama.at/getattachment/0543decc-1af648ac-94c0-3a6048dfebf1/MEB_Oepul2015_Erosionsschutz_Obst-WeinHopfen_3-0.pdf (accessed 18 April 2019).

AMBIAUd, É., (2012) Moins de désherbantsdans les vignes. Agreste Primeur. Available from: http://agreste.agriculture.gouv.fr/IMG/pdf/primeur288-2.pdf (accessed 7 May 2019).

Anderson, K., \& JenSeN, H.G., (2016) How Much Government Assistance Do European Wine Producers Receive? Journal of Wine Economics 11(2): 289-305.

ANDERSON, K., \& PinilLA, V., (2017) Annual Database of Global Wine Markets, 1835 to 2016. Wine Economics Research Centre, University of Adelaide. Available from: https://www.adelaide.edu.au/wine-econ/databases/global-wine-history/ (accessed 24 May 2018).

ANDERSON, K., \& WitTWER, G., (2013) Modeling Global Wine Markets to 2018: Exchange Rates, Taste Changes, and China's Import Growth. Journal of Wine Economics 8(02): 131-158.

Anderson, K., Nelgen, S., \& Pinilla, V., (2017) Global wine markets, 1860 to 2016: a statistical compendium. University of Adelaide Press. Available from: http://www.oapen.org/search?identifier=641652 (accessed 21 March 2018).

ARBUCKLE, J.G., \& RoESCH-McNAlLY, G., (2015) Cover crop adoption in Iowa: The role of perceived practice characteristics. Journal of Soil and Water Conservation 70(6): 418-429.

ARNold, C.A. (TONY), \& GUNDERSON, L., (2013) Adaptive Law and Resilience. SSRN Scholarly Paper, Rochester, NY: Social Science Research Network. Available from: https://papers.ssrn.com/abstract=2225619 (accessed 7 May 2019). 
ArriazA, M., Cañas-Ortega, J.F., CAÑAS-Madueño, J.A., et AL., (2004) Assessing the visual quality of rural landscapes. Landscape and Urban Planning 69(1): 115-125.

AUERSWALD, K., \& SCHWAB, S., (1999) Erosion risk (C factor) of different viticultural practices. Vitic. Enol. Sci (54): 54-60.

BAGAGIOLO, G., BIDDOCCU, M., RABINO, D., ET AL., (2018) Effects of rows arrangement, soil management, and rainfall characteristics on water and soil losses in Italian sloping vineyards. Environmental Research 166: 690-704.

BAllabio, C., BORRelli, P., SPINONI, J., ET AL., (2017) Mapping monthly rainfall erosivity in Europe. Science of The Total Environment 579: 1298-1315.

BARNier, T., (2012) Référentiel Technico -Economique du Vigneron Bordelais Mieux connaître les coûts de production. Available from: https://www.academia.edu/31893592/R\%C3\%A9f\%C3\%A9rentiel_Technico_Economique_du_Vigneron_Bordelais_Mieux_conna\%C3\%AEtre_les_co\%C3\%BBts _de_production (accessed 7 May 2019).

BARRIOS, E., (2007) Soil biota, ecosystem services and land productivity. Ecological Economics 64(2): 269-285.

BATÁRY, P., DiCKS, L.V., KLEJN, D., ET AL., (2015) The role of agri-environment schemes in conservation and environmental management. Conservation Biology 29(4): 1006-1016.

BegUM, M., GURR, G.M., WRATTEN, S.D., ET AL., (2006) Using selective food plants to maximize biological control of vineyard pests. Journal of Applied Ecology 43(3): 547-554.

BenCKISER, G., (ED.) (1997) Fauna in Soil Ecosystems - Recycling Processes, Nutrient Fluxes, and Agricultural Production. 1st ed. Boca Raton: CRC Press. Available from: https://www.taylorfrancis.com/books/e/9780429152795 (accessed 7 May 2019).

BERNDT, L.A., WRATTEN, S.D., \& SCARRATT, S.L., (2006) The influence of floral resource subsidies on parasitism rates of leafrollers (Lepidoptera: Tortricidae) in New Zealand vineyards. Biological Contro/37(1): 50-55.

BetTini, O., (2015) EU-27 Wine Annual Report and Statistics 2015. GAIN Report, USDA Foreign Agricultural Service. Available from:

http://gain.fas.usda.gov/Recent\%20GAIN\%20Publications/Wine\%20Annual_Rom e_EU-28_3-16-2015.pdf.

BIDDOCCU, M., FERRARIS, S., OPSI, F., ET AL., (2016) Long-term monitoring of soil management effects on runoff and soil erosion in sloping vineyards in Alto Monferrato (North-West Italy). Soil and Tillage Research 155: 176-189.

BlaVet, D., De Noni, G., Le BissonNAis, Y., ET AL., (2009) Effect of land use and management on the early stages of soil water erosion in French Mediterranean vineyards. Soil and Tillage Research 106(1): 124-136.

BLOOR, M., FRANKLAND, J., THOMAS, M., ET AL., (2001) Focus groups in social research. Introducing qualitative methods, London: Sage. 
Boller, E.F., GUt, D., \& ReMUND, U., (1997) Biodiversity in Three Trophic Levels of the Vineyard Agro-Ecosystem in Northern Switzerland. In: Dettner PDK, Bauer PDG, and Völkl DW (eds), Vertical Food Web Interactions, Ecological Studies, Springer Berlin Heidelberg, pp. 299-318. Available from: http://link.springer.com/chapter/10.1007/978-3-642-60725-7_17 (accessed 22 May 2015).

BORSELLI, L., TORRI, D., POESEN, J., ET AL., (2012) A robust algorithm for estimating soil erodibility in different climates. CATENA 97: 85-94.

BROMLEY, D.W., \& HODGE, I., (1990) Private property rights and presumptive policy entitlements: reconsidering the premises of rural policy. European Review of Agricultural Economics 17(2): 197-214.

Brugarolas, M., Martinez-Carrasco, L., BernabeU, R., et Al., (2009) A contingent valuation analysis to determine profitability of establishing local organic wine markets in Spain. Renewable Agriculture and Food Systems 25(1): 35-44.

BRUSSAARD, L., (1998) Soil fauna, guilds, functional groups and ecosystem processes. Applied Soil Ecology 9(1): 123-135.

BuCHHOlZ, J., QUERNer, P., PAREDES, D., ET AL., (2017) Soil biota in vineyards are more influenced by plants and soil quality than by tillage intensity or the surrounding landscape. Scientific Reports 7(1): 17445.

BUNDESANSTALT FÜR AGRARWIRTSCHAFT (n.d.) Weinbau Traubenproduktion - AWI Deckungsbeiträge und Kalkulationsdaten. Available from: https://idb.awi.bmlfuw.gv.at/version2/traubenproduktion (accessed 2 February 2018).

BÜNEMANN, E.K., MÄDER, P., WOHLFAHRT, J., ET AL., (2016) Concepts and indicators of soil quality - a review. iSQAPER, Deliverable D 3.1. Available from: https://ec.europa.eu/research/participants/documents/downloadPublic?docume ntIds=080166e5ae63cb0e\&appId=PPGMS.

CAREY, M.A., \& AsbuRY, J.-E., (2016) Focus Group Research. Routledge.

CARTER, E.A., (2012) Cooperation, Competition, and Regulation: Constructing Value in French and Italian Wine Markets. UC Berkeley. Available from: https://escholarship.org/uc/item/8w505189 (accessed 7 May 2019).

Cebulla, B., (2018) Vivino - How much does a good bottle of wine cost? Vivino. Available from: https://www.vivino.com/wine-news/how-much-does-a-goodbottle-of-wine-cost (accessed 7 May 2019).

CERIN, P., (2006) Bringing economic opportunity into line with environmental influence: A discussion on the Coase theorem and the Porter and van der Linde hypothesis. Ecological Economics 56(2): 209-225.

Chambre d'Agriculture de l'Hérault (ED.) (2013) Cout de Plantation D'une Vigne Palissee. 
Chambre d'AGRICULture De L'Hérault (2019) Coûts de plantation. Available from: https://herault.chambre-agriculture.fr/gerer-son-exploitation/juridique-etfoncier/couts-de-plantation/ (accessed 7 May 2019).

COASE, R.H., (1960) The Problem of Social Cost. In: Gopalakrishnan C (ed.), Classic Papers in Natural Resource Economics, London: Palgrave Macmillan, pp. 87-137. Available from: https://doi.org/10.1057/9780230523210_6 (accessed 30 April 2019).

CODE DE LA CONSOMMATION ARTICLE L431-1 (n.d.). Available from:

https://www.legifrance.gouv.fr/affichCode.do;jsessionid=8C50CA42BA9FD84D9B E8E644995164DE.tplgfr43s_2?idSectionTA=LEGISCTA000032225410\&cidTexte $=$ L EGITEXT000006069565\&dateTexte $=20190507$ (accessed 7 May 2019).

CODE RURAL ET DE LA PÊCHE MARITIME (n.d.) Code rural et de la pêche maritime - Article L641-5.

CORSI, A., \& StRøM, S., (2013) The Price Premium for Organic Wines: Estimating a Hedonic Farm-Gate Price Equation. Journal of Wine Economics 8(1): 29-48.

DABNEY, S.M., YODER, D.C., \& VieIRA, D. A. N., (2012) The application of the Revised Universal Soil Loss Equation, Version 2, to evaluate the impacts of alternative climate change scenarios on runoff and sediment yield. Journal of Soil and Water Conservation 67(5): 343-353.

Defrancesco, E., Gatto, P., Runge, F., et AL., (2008) Factors Affecting Farmers' Participation in Agri-environmental Measures: A Northern Italian Perspective. Journal of Agricultural Economics 59(1): 114-131.

Della-Marta, P.M., Luterbacher, J., von WeisSenfluh, H., et Al., (2007) Summer heat waves over western Europe 1880-2003, their relationship to large-scale forcings and predictability. Climate Dynamics 29(2): 251-275.

DG AGRI (2013) Overview of CAP Reform 2014-2020. Agricultural Policy Perspectives Brief, European Commission. Available from: https://ec.europa.eu/agriculture/sites/agriculture/files/policyperspectives/policy-briefs/05_en.pdf.

DG AGRI (ED.) (2015a) Member States Factsheets - European Union. Available from: http://ec.europa.eu/agriculture/statistics/factsheets/index_en.htm (accessed 26 November 2015).

DG AGRI (ED.) (2015b) Wine - Market Situation: Evolution and Background information. Available from: http://ec.europa.eu/agriculture/wine/statistics/market-situation2014-07_en.pdf (accessed 24 November 2015).

DG IPOL (ED.) (2012) The liberalisation of planting rights in the EU wine sector. Brussels. Available from: http://bookshop.europa.eu/en/the-liberalisation-of-plantingrights-in-the-eu-wine-sector-pbBA3112158/ (accessed 25 November 2015).

DPA (2015) Weinimperium Frankreich durch Klimawandel bedroht. proplanta.de. Available from: https://www.proplanta.de/AgrarNachrichten/Pflanze/Weinimperium-Frankreich-durch-Klimawandelbedroht_article1446107231.html (accessed 25 April 2019). 
DPA/LRS, (2016) Weinabsatz sinkt durch alternde Gesellschaft. proplanta Nachrichten. Available from: http://www.proplanta.de/AgrarNachrichten/Pflanze/Weinabsatz-sinkt-durch-alterndeGesellschaft_article1452678927.html (accessed 20 January 2016).

ELO, S., \& KYNGÄS, H., (2008) The qualitative content analysis process. Journal of Advanced Nursing 62(1): 107-115.

EUROPEAN COMMISSION (2011) EU biodiversity strategy to 2020. Available from: http://eur-lex.europa.eu/legal-content/ENDE/TXT/?uri=CELEX:52011DC0244\&from=EN (accessed 5 October 2015).

EUROPEAN COMMISSION (2015a) Cross-compliance. European Commission - Agriculture and rural development - Direct support - Cross-compliance, Text. Available from: https://ec.europa.eu/agriculture/direct-support/cross-compliance_en (accessed 30 April 2019).

EUROPEAN COMMISSION (ED.) (2015b) Monitoring EU Agri-Food Trade: Development until August 2015. Available from: http://ec.europa.eu/agriculture/tradeanalysis/monitoring-agri-food-trade/2015-11_en.pdf (accessed 24 November 2015).

EUROPEAN COMMISSION (2016a) Annual Agri-food trade report 2015: EU still world's leading exporter. MAP, Monitoring Agri-trade Policy. Available from: https://ec.europa.eu/agriculture/sites/agriculture/files/trade-analysis/map/20161_en.pdf.

EUROPEAN COMMISSION (2016b) The reforms of the EU wine market. Agriculture and rural development - European Commission, Text. Available from: https://ec.europa.eu/agriculture/wine/reforms_en (accessed 26 April 2019).

EUROPEAN COMMISSION (2017) EU Agricultural outlook for the agricultural markets and income 2017-2030. Available from: https://ec.europa.eu/agriculture/sites/agriculture/files/markets-andprices/medium-term-outlook/2017/2017-fullrep_en.pdf (accessed 5 March 2018).

EUROPEAN COMMISSION \& DG AGRI (2012) Evaluation of the Common Agricultural Policy measures applied to the wine sector. Executive summary. Available from: http://bookshop.europa.eu/en/evaluation-of-the-common-agricultural-policymeasures-applied-to-the-wine-sector-pbKF0213244/ (accessed 7 October 2015).

EUROPEAN COMMISSION \& DG AGRI (2014) Study on the competitiveness of European wines. Final Report, Luxembourg. Available from: http://bookshop.europa.eu/en/study-on-the-competitiveness-of-europeanwines-pbKF0214995/ (accessed 7 October 2015).

EUROPEAN UNION (2013) Regulation (EU) No 1308/2013 of the European Parliament and of the Council of 17 December 2013 establishing a common organisation of the markets in agricultural products and repealing Council Regulations (EEC) No 922/72, (EEC) No 234/79, (EC) No 1037/2001 and (EC) No 1234/2007. OJ L. 
Available from: http://data.europa.eu/eli/reg/2013/1308/oj/eng (accessed 3 December 2018).

EUROSTAT (2007) The use of plant protection products in the European Union Data 1992-2003. Available from:

http://ec.europa.eu/eurostat/documents/3217494/5611788/KS-76-06-669EN.PDF.

EUROSTAT (2017) Agriculture, forestry and fishery statistics - 2017 edition. Statistical books, Luxembourg: Publications Office of the European Union. Available from: http://ec.europa.eu/eurostat/web/products-statistical-books/-/KS-FK-17-001 (accessed 6 March 2018).

FAO (n.d.) FAO Statistical Database. Available from: http://www.fao.org/faostat/en/\#home (accessed 30 January 2017).

Forte, V., ANGelini, E., MAIXNer, M., ET AL., (2010) Preliminary results on population dynamics and host plants of Hyalesthes obsoletus in North-Eastern Italy. VITIS Journal of Grapevine Research 49(1): 39-42.

FOURIE, J.C., \& FREITAG, K., (2010) Soil management in the Breede River Valley wine grape region, South Africa. 2. Soil temperature. South African Journal of Enology and Viticulture 31(2): 165-168.

FranceAgriMer (2015) Ventes et achats de vins tranquilles 2014. Établissement national des produits de l'agriculture et de la mer. Available from: https://www.franceagrimer.fr/content/download/38473/354639/file/SYNVIN\%20Ventes\%20et\%20achats\%20de\%20vins\%20tranquilles\%202014.pdf (accessed 7 May 2019).

Galati, A., GristinA, L., CRescimanno, M., et AL., (2015) Towards More Efficient Incentives for Agri-environment Measures in Degraded and Eroded Vineyards. Land Degradation \& Development 26(6): 557-564.

Gaupp-Berghausen, M., Hofer, M., ReWALD, B., ET AL., (2015) Glyphosate-based herbicides reduce the activity and reproduction of earthworms and lead to increased soil nutrient concentrations. Scientific Reports 5: 12886.

Giese, G., Velasco-Cruz, C., Roberts, L., ET AL., (2014) Complete vineyard floor cover crops favorably limit grapevine vegetative growth. Scientia Horticulturae 170: 256266.

GilinSkY, A., NEWTON, S.K., \& VEGA, R.F., (2016) Sustainability in the Global Wine Industry: Concepts and Cases. Agriculture and Agricultural Science Procedia, Florence "Sustainability of Well-Being International Forum". 2015: Food for Sustainability and not just food, FlorenceSWIF2015 8: 37-49.

GómEZ, J.A., LLEWELLYN, C., BASCH, G., ET AL., (2011) The effects of cover crops and conventional tillage on soil and runoff loss in vineyards and olive groves in several Mediterranean countries. Soil Use and Management 27(4): 502-514.

GómEZ, J.A., BIDDOCCU, M., GuZMÁN, G., ET AL., (2018) Determination of soil cover and management factor $(C)$ for RUSLE and evaluation of erosion risk in vineyards at five vine growing regions across Europe with different soil management 
intensities. In: Proceedings from the conference held 4-13 April, 2018 in Vienna, Austria, p. 9619. Available from:

http://adsabs.harvard.edu/abs/2018EGUGA..20.9619G (accessed 17 April 2019).

GÖRLACH, B., LANDGReBe-TrinkUnAite, R., INTERWies, E., ET AL., (2004) Assessing the Economic Impacts of Soil Degradation. Volume III: Empirical Estimation of the Impacts. Study Contract ENV.B.1/ETU/2003/0024, Study commissioned by the European Commission, DG Environment.

GUYTON, K.Z., LOOMIS, D., GROSSE, Y., ET AL., (2015) Carcinogenicity of tetrachlorvinphos, parathion, malathion, diazinon, and glyphosate. The Lancet Oncology 16(5): 490-491.

GuZMÁN, G., CABEZAS, J.M., SÁNCHEZ-CuestA, R., ET AL., (2019) A field evaluation of the impact of temporary cover crops on soil properties and vegetation communities in southern Spain vineyards. Agriculture, Ecosystems \& Environment 272: 135145.

HARTMANN, M., NÖTH, C., \& SCHMitZ, P.M., (1993) Instrumente und Modelle zur Analyse und Formulierung von Agrarpolitiken in Entwicklungsländern: Frankfurter volkswirtschaftliche Diskussionsbeiträge. - Frankfurt, M, 1990-, Frankfurt/Main: Johann-Wolfgang-Goethe-Univ., Fachbereich Wirtschaftswiss.

HAUCK, J., SCHMIDT, J., \& WERNER, A., (2016) Using social network analysis to identify key stakeholders in agricultural biodiversity governance and related land-use decisions at regional and local level. Ecology and Society 21(2). Available from: http://www.ecologyandsociety.org/vol21/iss2/art49/ (accessed 8 December 2016).

HeRvÉ, M.E.T., BOUdeS, P., CIESLIK, C., ET AL., (2018) Landscape complexity perception and representation in a wine-growing region with the designation of origin in the Loire Valley (France): a cultural ecosystem service? Renewable Agriculture and Food Systems. 1-13.

HofFMANN, D., (2015) Der Weinmarkt. German Journal of Agricultural Economics 64(Suppl.): 62-70.

HolzGANG, O., GUT, D., \& GIGON, A., (1996) Weed control methods to improve plant species richness in vineyards. In: Proceedings, Second International Weed Contro/ Congress, Copenhagen, Denmark, Copenhagen: Department of Weed Control and Pesticide Ecology, pp. 225-234.

HSIEH, H.-F., \& SHANNON, S.E., (2005) Three Approaches to Qualitative Content Analysis. Qualitative Health Research 15(9): 1277-1288.

IPBES (2019) Media Release: Nature's Dangerous Decline 'Unprecedented'; Species Extinction Rates 'Accelerating' | IPBES. ipbes - Science and Policy for People and Nature, Intergovernmental Science-Policy Platform on Biodiversity and Ecosystem Services. Available from: https://www.ipbes.net/news/Media-ReleaseGlobal-Assessment\#_ftn1 (accessed 7 May 2019).

JUNTA DE ANDALUCiA (2003) Diagnóstico del sector vitivinícola en el Marco de MontillaMoriles. Available from: 
https://www.juntadeandalucia.es/agriculturaypesca/portal/export/sites/default/c omun/galerias/galeriaDescargas/cap/servicio-estadisticas/Estudios-einformes/historico/vitivinicola/diagnost_viti_montilla.pdf (accessed 16 March 2018).

JUNTA DE ANDALUCIA (2018) Uva de vinificación. Observatorio de Precios y Mercados. Consejería de Agricultura, Pesca y Desarrollo Rural. Junta de Andalucía. Available from: https://www.juntadeandalucia.es/agriculturaypesca/observatorio/servlet/FrontC ontroller?action=Static\&subsector $=60 \&$ url=subsector.jsp (accessed 6 February 2019).

KHARAS, H., (2017) The unprecedented expansion of the global middle class: An update. Global Economy \& Development Working Paper, Brookings Institution 100. Available from: https://think-asia.org/handle/11540/7251 (accessed 25 April 2019).

Kitzinger, J., \& BARBour, R., (1999) Developing Focus Group Research: Politics, Theory and Practice. London: SAGE.

KLIK, A., \& EITZINGER, J., (2010) Impact of climate change on soil erosion and the efficiency of soil conservation practices in Austria. The Journal of Agricultural Science 148(5): 529-541.

Kouli, M., SOUPiOS, P., \& VAllianatos, F., (2009) Soil erosion prediction using the Revised Universal Soil Loss Equation (RUSLE) in a GIS framework, Chania, Northwestern Crete, Greece. Environmental Geology 57(3): 483-497.

KRABBE, Ø.E., \& ViNK, N., (2000) Searching for Comparative Advantage in Commercial Sugarcane Production in South Africa: A Pam Analysis. Agrekon 39(2): 161-173.

Kratschmer, S., PAChinger, B., SChWANtzer, M., et Al., (2019) Response of wild bee diversity, abundance, and functional traits to vineyard inter-row management intensity and landscape diversity across Europe. Ecology and Evolution 9(7): 4103-4115.

KRIEBEL DTICKNER JEPSTEIN PET AL., (2001) The precautionary principle in environmental science. Environmental Health Perspectives 109(9): 871-876.

KRIPPENDORFF, K., (1989) Content Analysis. International Encyclopedia of Communication. 403-407.

KRUEGER, R.A., \& CASEY, M.A., (2015) Focus Groups A practical Guide for applied research. 5 Rev ed. Thousand Oaks, California: Sage Publications Inc.

KTBL (ED.) (2018) Faustzahlen für die Landwirtschaft. 15th ed. Zarbock.

KYDD, J., PEARCE, R., \& STOCKBRIDGE, M., (1997) The economic analysis of commodity systems: Extending the Policy Analysis Matrix to account for environmental effects and transactions costs. Agricultural Systems, Socio-economic Methods in Renewable Natural Resources Research 55(2): 323-345.

LAFERTÉ, G., (2003) La mise en folklore des vins de Bourgogne: la «Paulée » de Meursault. Ethnologie francaise Vol. 33(3): 435-442. 
LaItHWAite's Wine (n.d.) Toro Albalá Pedro Ximénez Convento Selección 1931. Available from: https://www.laithwaites.co.uk (accessed 27 April 2019).

LAKEMEYER, E., (2007) Die Produktion von Biokraftstoffen und insbesondere Biodiesel in der Ukraine und die Entwicklung des Rapsmarktes: eine Betrachtung mit Hilfe der Politik Analyse Matrix. 1st ed. Göttingen: Cuvillier.

LANDWIRTSCHAFTSKAMMER ÖSTERREICH (2019) Landwirtschaftskammer - Weinbau Rechtliches und Förderungen. Available from: https://www.lko.at/rechtlichesund-f\%C3\%B6rderungen $+2500++2730673+7548$ (accessed 26 April 2019).

Lastra-Bravo, X.B., HubBard, C., Garrod, G., et AL., (2015) What drives farmers' participation in EU agri-environmental schemes?: Results from a qualitative meta-analysis. Environmental Science \& Policy 54: 1-9.

LESCOT, J.-M., ROUIRE, M., RAYNAL, M., ET AL., (2014) Bio-economic modeling of wine grape protection strategies for environmental policy assessment. Operational Research 14(2): 283-318.

LindeMANN-MATthieS, P., JUNGE, X., \& MATTHIES, D., (2010) The influence of plant diversity on people's perception and aesthetic appreciation of grassland vegetation. Biological Conservation 143(1): 195-202.

Loire VAlley Wine Bureau (2016) COTEAUX DU LAYON. Loire Valley Wines. Available from: https://www.vinsvaldeloire.fr/en/wine/coteaux-du-layon (accessed 29 August 2018).

Loire Valley Wine Bureau (2018a) Coteaux du Layon | Loire Valley Wines. Available from: http://preprod.loirevalleywine.com/appellation/coteaux-du-layon/ (accessed 24 March 2018).

LOIRE VALley Wine BUREAU (2018b) Loire Valley Wines. Available from: https://www.vinsvaldeloire.fr/en/rechercher-un-vin (accessed 24 March 2018).

LOUChART, X., VoltZ, M., ANDRIEUX, P., ET AL., (2001) Herbicide Transport to Surface Waters at Field and Watershed Scales in a Mediterranean Vineyard Area. Journal of Environmental Quality 30(3): 982-991.

LUCCHI, A., LADURNER, E., IODICE, A., ET AL., (2018) ECo-friendly pheromone dispensers-a green route to manage the European grapevine moth? Environmental Science and Pollution Research International; Heidelberg 25(10): 9426-9442.

MACE, G.M., (2014) Biodiversity: Its Meanings, Roles, and Status. 1st ed. In: Helm D and Hepburn C (eds), Nature in the balance: the economics of biodiversity, Oxford: Oxford Univ. Press, pp. 35-56.

Marques, M.J., Bienes, R., Cuadrado, J., et Al., (2015) Analysing Perceptions Attitudes and Responses of Winegrowers about Sustainable Land Management in Central Spain. Land Degradation \& Development 26(5): 458-467.

MARTíneZ-CASASNOVAS, J.A., \& RAMOS, M.C., (2006) The cost of soil erosion in vineyard fields in the Penedès-Anoia Region (NE Spain). CATENA, Soil Erosion Research in Europe 68(2): 194-199. 
Martins, G., LAUGA, B., MiOt-Sertier, C., ET AL., (2013) Characterization of Epiphytic Bacterial Communities from Grapes, Leaves, Bark and Soil of Grapevine Plants Grown, and Their Relations. PLOS ONE 8(8): e73013.

MASTERS, W.A., \& Winter-Nelson, A., (1995) Measuring the Comparative Advantage of Agricultural Activities: Domestic Resource Costs and the Social Cost-Benefit Ratio. American Journal of Agricultural Economics 77(2): 243-250.

MAYRING, P., (2015) Qualitative Inhaltsanalyse: Grundlagen und Techniken. 12., überarbeitete Auflage. Weinheim: Beltz.

MCGouRTY, G., \& REGANOLD, J., (2005) Managing Vineyard Soil Organic Matter with Cover Crops. In: Proceedings of the soil environment and vine mineral nutrition symposium, San Diego: ASEV, pp. 145-151.

Medrano, H., TOMÁS, M., MARTORELL, S., ET AL., (2015) Improving water use efficiency of vineyards in semi-arid regions. A review. Agronomy for Sustainable Development 35(2): 499-517.

Meloni, G., \& SWinNen, J., (2013) The Political Economy of European Wine Regulations. Journal of Wine Economics 8(03): 244-284.

Meloni, G., \& SWinnen, J., (2016) The Political and Economic History of Vineyard Planting Rights in Europe: From Montesquieu to the European Union. Journal of Wine Economics 11(3): 379-413.

MenapaCe, L., Colson, G., \& Raffaelli, R., (2013) Risk Aversion, Subjective Beliefs, and Farmer Risk Management Strategies. American Journal of Agricultural Economics 95(2): 384-389.

Menghi, A., De Roest, K., Porcelluzzi, A., et AL., (2011) Assessing Farmers' Cost of Compliance with EU Legislation in the Fields of Environment, Animal Welfare and Food Safety: Final Report. Final Report, CRPA, TI, IFCN, UGHENT. Available from: https://ec.europa.eu/agriculture/sites/agriculture/files/externalstudies/2014/farmer-costs/fulltext_en.pdf.

Mercenaro, L., Nieddu, G., PulinA, P., ET Al., (2014) Sustainable management of an intercropped Mediterranean vineyard. Agriculture, Ecosystems \& Environment 192: 95-104.

Meteo France (n.d.) DONNEES CLIMATIQUES DE LA STATION DE BEAUCOUZÉ. Available from:

http://www.meteofrance.com/climat/france/beaucouze/49020001/normales (accessed 27 April 2017).

MilCU, A., PARTSCH, S., LANGEL, R., ET AL., (2006) The response of decomposers (earthworms, springtails and microorganisms) to variations in species and functional group diversity of plants. Oikos 112(3): 513-524.

Ministerio de Agricultura, Alimentación y Medio Ambiente (2016) Datos de las Denominaciones de origen protegidas de vinos (DOPs). Available from: http://www.mapama.gob.es/es/alimentacion/temas/calidadagroalimentaria/informedops2014-2015-web_tcm7-428808.pdf (accessed 16 March 2018). 
Ministerio de Agricultura, Pesca y Alimentación (n.d.) Denominaciones de Origen e Indicaciones Geográficas Protegidas - Cifras y datos. Available from: https://www.mapa.gob.es/es/alimentacion/temas/calidadagroalimentaria/calidad-diferenciada/dop/htm/cifrasydatos.aspx (accessed 7 February 2019).

MONKE, E.A., \& PEARSON, S.R., (1989) The policy analysis matrix for agricultural development. Agricultural economics, Ithaca, NY [u.a.]: Cornell Univ. Press.

MONTEIRO, A., \& LOPES, C.M., (2007) Influence of cover crop on water use and performance of vineyard in Mediterranean Portugal. Agriculture, Ecosystems \& Environment 121(4): 336-342.

MONTEIRO, A., LOPES, C., MACHADO, J.P., ET AL., (2008) Cover cropping in a sloping nonirrigated vineyard: II - Effects on vegetative growth, yield, berry and wine quality of 'Cabernet Sauvignon' grapevines.

MONTILLA MORILES - EL CLIMA (2016). Available from: http://www.montillamoriles.es/ladenominacion/viticultura/el-clima.html (accessed 30 October 2017).

Montilla-Moriles (2016) Estadísticas - Módulo Dinámico. Available from: https://www.montillamoriles.es/la-denominacion/conocenos/datos-deinteres/estadisticas.html (accessed 14 August 2018).

MORRISON, J., \& BALCOMBE, K., (2002) Policy analysis matrices: beyond simple sensitivity analysis. Journal of International Development 14(4): 459-471.

MosCHINI, G., \& HENNESSY, D.A., (2001) Chapter 2 Uncertainty, risk aversion, and risk management for agricultural producers. In: Handbook of Agricultural Economics, Agricultural Production, Elsevier, pp. 87-153. Available from: http://www.sciencedirect.com/science/article/pii/S1574007201100058 (accessed 26 September 2017).

Nelson, G.C., \& PANGGabean, M., (1991) The Costs of Indonesian Sugar Policy: A Policy Analysis Matrix Approach. American Journal of Agricultural Economics 73(3): 703-712.

NiVIEVSKYI, O., \& VON CRAMON-TAUBADEL, S., (2009) Measuring and Comparing the Competitiveness of Heterogeneous Production Systems in Agriculture: A Note. Outlook on Agriculture 38(1): 31-37.

NovarA, A., GristinA, L., SAladino, S.S., ET AL., (2011) Soil erosion assessment on tillage and alternative soil managements in a Sicilian vineyard. Soil and Tillage Research 117: 140-147.

OECD, (2018) Agricultural Policy Monitoring and Evaluation 2018. Available from: https://www.oecd-ilibrary.org/content/publication/agr_pol-2018-en.

OIV (2018a) 2018 World Vitiviniculture Situation - OIV Statistical Report on World Vitiviniculture. Available from: http://www.oiv.int/public/medias/6371/oivstatistical-report-on-world-vitiviniculture-2018.pdf (accessed 15 April 2019). 
OIV (2018b) State of the vitiviniculture world market April 2018. Available from: http://www.oiv.int/public/medias/5958/oiv-state-of-the-vitiviniculture-worldmarket-april-2018.pdf (accessed 3 December 2018).

OJeDA, H., BigARD, A., \& EsCudieR, J.L., (2017) De la vigne au vin: des créations variétales adaptées au changement climatique et résistant aux maladies cryptogamiques: Partie 2/2: Approche viticole pour des vins de type VDQA. Revue des oenologues et des techniques vitivinicoles et oenologicques: magazine trimestriel d'information professionnelle 44(165): 22-27.

OSteRATH, B., (2014) Duftstoffe ersetzen Gift im Weinberg. Deutsche Welle. Available from: https://www.dw.com/de/duftstoffe-ersetzen-gift-im-weinberg/a17881277 (accessed 11 April 2019).

ÖsterReiCH Wein (2018a) Carnuntum. Available from:

https://www.oesterreichwein.at/unserwein/weinbaugebiete/niederoesterreich/carnuntum/ (accessed 24 March 2018).

ÖSTERREICH WEIN (2018b) Dokumentation Österreich Wein 2016/2017. Available from: https://www.oesterreichwein.at/presse-multimedia/statistik/ (accessed 8 March 2019).

ÖSTERREICH WEIN (2018c) Leithaberg. Available from: https://www.oesterreichwein.at/unserwein/weinbaugebiete/burgenland/leithaberg/ (accessed 24 March 2018).

ÖSTERREICH WeIN (n.d.) Österreich Kartenmaterial. Available from: https://www.oesterreichwein.at/presse-multimedia/kartenmaterial/oesterreich/ (accessed 27 April 2019).

PACHeCo, F.A.L., VARANDAS, S.G.P., SANChes Fernandes, L.F., ET AL., (2014) Soil losses in rural watersheds with environmental land use conflicts. Science of The Total Environment 485-486: 110-120.

Panagos, P., Borrelli, P., POESEN, J., ET AL., (2015) The new assessment of soil loss by water erosion in Europe. Environmental Science \& Policy 54: 438-447.

PANAGOS, P., StANDARDi, G., BORRelLi, P., ET AL., (2018) Cost of agricultural productivity loss due to soil erosion in the European Union: From direct cost evaluation approaches to the use of macroeconomic models. Land Degradation \& Development 29(3): 471-484.

Pardini, A., FAiello, C., LONGHI, F., ET AL., (2002) Cover crop species and their management in vineyards and olive groves. Advances in Horticultural Science 16(3/4): 225234.

PeARSON, S.R., GotsCH, C., \& BAHRI, S., (2003) Applications of the Policy Analysis Matrix in Indonesian Agriculture. Available from:

http://web.stanford.edu/group/FRI/indonesia/newregional/newbook.htm.

Peregrina, F., Pérez-Álvarez, E.P., Colina, M., et Al., (2012) Cover crops and tillage influence soil organic matter and nitrogen availability in a semi-arid vineyard. Archives of Agronomy and Soil Science 58(sup1): SS95-SS102. 
Pérez-ÁlvareZ, E.P., Garde-Cerdán, T., SANTAMaría, P., eT AL., (2015) Influence of two different cover crops on soil $\mathrm{N}$ availability, $\mathrm{N}$ nutritional status, and grape yeastassimilable N (YAN) in a cv. Tempranillo vineyard. Plant and Soil390(1): 143156.

PHYTOWELT GMBH (2003) Study on the use of the varieties of interspecific vines. Final Report. Available from: http://ec.europa.eu/agriculture/markets/wine/studies/vine_en.pdf.

Pimentel, D., Harvey, C., Resosudarmo, P., ET AL., (1995) Environmental and Economic Costs of Soil Erosion and Conservation Benefits. Science 267(5201): 1117-1123.

PlaAs, E., Meyer-Wolfarth, F., Banse, M., ET AL., (2019) Towards valuation of biodiversity in agricultural soils: A case for earthworms. Ecological Economics 159: 291-300.

Plieninger, T., Bieling, C., Fagerholm, N., et AL., (2015) The role of cultural ecosystem services in landscape management and planning. Current Opinion in Environmental Sustainability, Open Issue 14: 28-33.

PORTER, M.E., \& VAN DER LINDE, C., (1995) Toward a New Conception of the EnvironmentCompetitiveness Relationship. The Journal of Economic Perspectives 9(4): 97118.

Presentationgo (2018) Europe Editable PowerPoint Map. The Free PowerPoint Template Library. Available from: https://www.presentationgo.com/presentation/europe-editable-powerpointmap/ (accessed 27 April 2019).

Pretty, J.N., Brett, C., GeE, D., ET AL., (2000) An assessment of the total external costs of UK agriculture. Agricultural Systems 65(2): 113-136.

Prosdocimi, M., CERdÀ, A., \& TAROlLI, P., (2016) Soil water erosion on Mediterranean vineyards: A review. CATENA 141: 1-21.

RAMírez PÉREZ, P., \& LASHeRAS OCAÑA, J.M., (2016) Guía de cubiertas vegetales en viñedo. Junta de Andalucía. Consejería de Agricultura, Pesca y Desarrollo Rural Instituto de Investigación y Formación Agraria y Pesquera. Available from: https://www.juntadeandalucia.es/agriculturaypesca/ifapa/servifapa/contenidoAlf ?id=e9382a80-a6a7-495d-a932-026a1783e6e4 (accessed 18 April 2019).

Renaud, A., Poinsot-Balaguer, N., CORTet, J., ET AL., (2004) Influence of four soil maintenance practices on Collembola communities in a Mediterranean vineyard. Pedobiologia 48(5): 623-630.

Rodrigo Comino, J., SENCIALES, J.M., RAMOS, M.C., ET AL., (2017) Understanding soil erosion processes in Mediterranean sloping vineyards (Montes de Málaga, Spain). Geoderma 296: 47-59.

RosA, J.D., MAfrA, A.L., Medeiros, J.C., ET AL., (2013) Soil physical properties and grape yield influenced by cover crops and management systems. Revista Brasileira de Ciência do Solo 37(5): 1352-1360. 
Ruíz-Colmenero, M., BieneS, R., EldRidGe, D.J., ET AL., (2013) Vegetation cover reduces erosion and enhances soil organic carbon in a vineyard in the central Spain. CATENA 104: 153-160.

RUSCH, A., DELBAC, L., \& THIÉRY, D., (2017) Grape moth density in Bordeaux vineyards depends on local habitat management despite effects of landscape heterogeneity on their biological control. Journal of Applied Ecology 54(6): 1794-1803.

SANGUANKEO, P.P., \& LEÓN, R.G., (2011) Weed management practices determine plant and arthropod diversity and seed predation in vineyards. Weed Research 51(4): 404-412.

SATTLER, C., \& NAGEL, U.J., (2010) Factors affecting farmers' acceptance of conservation measures-A case study from north-eastern Germany. Land Use Policy, Soil and Water Conservation Measures in Europe 27(1): 70-77.

SCHÄUfELE, I., \& HAMM, U., (2017) Consumers' perceptions, preferences and willingnessto-pay for wine with sustainability characteristics: A review. Journal of Cleaner Production 147: 379-394.

SCHULZ, M., MACK, B., \& ReNN, O., (2012) Fokusgruppen in der empirischen Sozialwissenschaft: von der Konzeption bis zur Auswertung. Wiesbaden: Springer VS.

SCHÜTTE, R., \& BERGMANN, H., (2019) The attitudes of French and Spanish winegrowers towards the use of cover crops in vineyards. Journal of Wine Research. DOI: 10.1080/09571264.2019.1568975

SPILlER, R., (2015) Motivation von Seniorinnen und Senioren zur sportlichen Betätigung:: Eine empirische Untersuchung mittels qualitativer Interviews in und um Göttingen.

SteENWERTH, K., \& BeLINA, K.M., (2008) Cover crops enhance soil organic matter, carbon dynamics and microbiological function in a vineyard agroecosystem. Applied Soil Ecology 40(2): 359-369.

Steenwerth, K.L., MCElrone, A.J., Calderón-OrellanA, A., et Al., (2013) Cover Crops and Tillage in a Mature Merlot Vineyard Show Few Effects on Grapevines. American Journal of Enology and Viticulture 64(4): 515-521.

StRAUSS, A., \& CORBIN, J.M., (1998) Basics of qualitative research: techniques and procedures for developing grounded theory. 2nd ed. Thousand Oaks [u.a.]: Sage Publ.

TRAVERSAC, J.-B., Rousset, S., \& PeRrier-Cornet, P., (2011) Farm resources, transaction costs and forward integration in agriculture: Evidence from French wine producers. Food Policy, Between the Global and the Local, the Material and the Normative: Power struggles in India's Agrifood System 36(6): 839-847.

Uliarte, E.M., SChUltz, H.R., Frings, C., ET AL., (2013) Seasonal dynamics of CO2 balance and water consumption of $\mathrm{C} 3$ and C4-type cover crops compared to bare soil in a suitability study for their use in vineyards in Germany and Argentina. Agricultural and Forest Meteorology 181: 1-16. 
UN GeNERAL ASSEMBLY (2015) Transforming our world: the 2030 Agenda for Sustainable Development: A/RES/70/1. Available from: https://sustainabledevelopment.un.org/post2015/transformingourworld (accessed 29 April 2019).

URRUTY, N., DEVEAUD, T., GUYOMARD, H., ET AL., (2016) Impacts of agricultural land use changes on pesticide use in French agriculture. European Journal of Agronomy 80: 113-123.

Villanueva, A.J., Gómez-Limón, J.A., ARRiAZA, M., ET AL., (2015) The design of agrienvironmental schemes: Farmers' preferences in southern Spain. Land Use Policy 46: $142-154$.

VUKICEVICH, E., LOWERY, T., BOWEN, P., ET AL., (2016) Cover crops to increase soil microbial diversity and mitigate decline in perennial agriculture. A review. Agronomy for Sustainable Development 36(3): 48.

WeBER, R.P., (1990) Basic Content Analysis. SAGE. Available from: http://hbanaszak.mjr.uw.edu.pl/TempTxt/_Basic_Content_Analysis_Quantitative _Applications_in_the_Social_Sciences_.pdf.

WENGE, J., (2017) Ende des Komasaufens: Junge Leute trinken weniger Alkohol. Available from: https://www.faz.net/1.5022425 (accessed 25 April 2019).

WinKLER, K.J., \& NiCHOLAS, K.A., (2016) More than wine: Cultural ecosystem services in vineyard landscapes in England and California. Ecological Economics 124: 86-98.

WinTER, S., (2015) Austrian study region - Carnuntum. Presentation Project Meeting VineDivers, Wien.

Winter, S., BAUER, T., StRAUSS, P., ET AL., (2018) Effects of vegetation management intensity on biodiversity and ecosystem services in vineyards: A meta-analysis. Journal of Applied Ecology 55(5): 2484-2495.

Wratten, S.D., Gillespie, M., DeCourtye, A., ET AL., (2012) Pollinator habitat enhancement: Benefits to other ecosystem services. Agriculture, Ecosystems \& Environment 159: 112-122.

XI, Z., TAO, Y., ZHANG, L., ET AL., (2011) Impact of cover crops in vineyard on the aroma compounds of Vitis vinifera L. cv Cabernet Sauvignon wine. Food Chemistry 127(2): 516-522.

YAO, S., (1997) Comparative Advantages and Crop Diversification: A Policy Analysis Matrix for Thai Agriculture. Journal of Agricultural Economics 48(1-3): 211-222.

ZALLER, J.G., HEIGL, F., RUESS, L., ET AL., (2014) Glyphosate herbicide affects belowground interactions between earthworms and symbiotic mycorrhizal fungi in a model ecosystem. Scientific Reports 4: 5634.

ZimmeRMANN, A., \& BRITZ, W., (2016) European farms' participation in agri-environmental measures. Land Use Policy 50: 214-228.

ZYL, J. VAN, ROOYEN, C.J. VAN, KIRSTEN, J.F., ET AL., (1994) Land reform in south africa: Options to consider for the future. Journal of International Development 6(2): 219-239. 


\section{Appendix A Focus Group Guideline}

Leading question

What incentives would policy have to provide to induce a change in the management of vineyards, with the aim of improving biodiversity?

\section{Opening questions}

1. Please tell us your name and where about your vineyard is situated.

2. How do you manage your vineyard? (conventional etc.)

\section{Key questions}

\section{Viniculture in the region}

3. How has viniculture in the region changed over the past years?

a. Do you think, that the management of vineyards has improved in terms of environmental protection?

4. Where do you see possibilities to support biodiversity in vineyards?

5. Do you have cover crops in the inter-rows?

a. (Why did you decide in favour, respectively against cover crops?)

Labour

6. How has the availability of workers changed over the past years?

a. Permanent vs. seasonal vs. family

b. Where do your workers come from?

Agricultural policy

7. How is your way of managing the vineyard affected by the agricultural policy?

a. Do you feel dis-/advantaged in relation to other farmers? In which way?

8. Do you take part in agri-environment measures?

a. Why or why not?

b. Would you take part in (further) agri-environment measures?

9. Do you use glyphosate in your vineyards?

a. What would you do, if the EU would not permit the usage anymore?

10. What would force you to change the management of your vineyards or even to give up the production of grapes?

\section{Ending questions}

11. Which chances or possibilities but also risks do you see for viniculture in this region in the future?

12. In your opinion, on what should we pay particularly attention in a policy recommendation which shall support biodiversity in viniculture?

13. Do you have any comments on this session? 


\section{Appendix B ORUSCAL}

Figure Appendix B-1: General construction of ORUSCAL

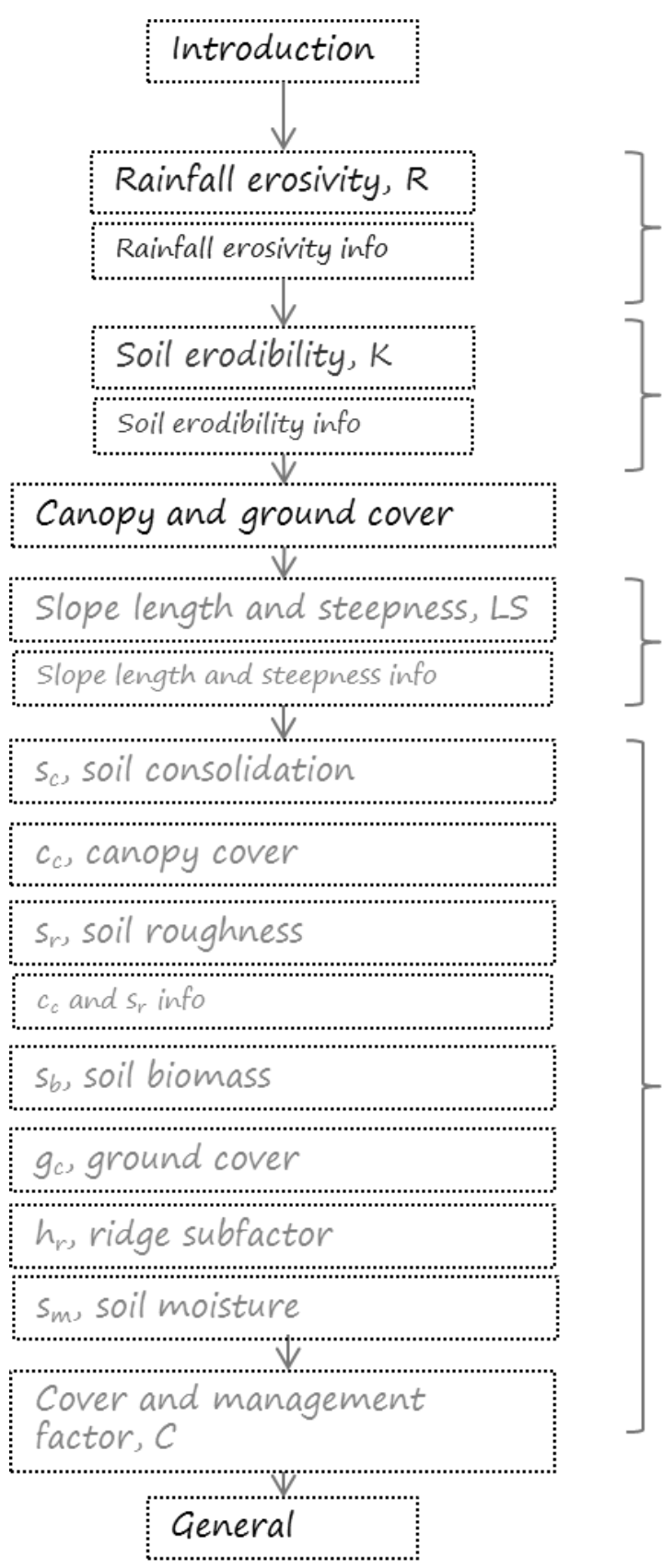

Basic instructions

Determination of $R$

Determination of $K$

Input on vegetation and residues

Determination of $\angle S$

Determination of $C$

Soil loss and factor values

Source: (GÓMEZ ET AL., 2018) 


\section{Appendix C PAM Austria}

Table Appendix C-1: Basic Budget Austria

\begin{tabular}{|c|c|c|c|c|c|c|}
\hline BASIC BUDGET AUSTRIA & Quantity & $\begin{array}{l}\text { Private } \\
\text { Price/ } \\
\text { 2uantity }\end{array}$ & $€ /$ ha & Quantity & $\begin{array}{c}\text { Social } \\
\text { Price/ } \\
\text { Quantity }\end{array}$ & $€ /$ ha \\
\hline \multicolumn{7}{|c|}{ Tradables } \\
\hline Chemicals (kg/ha) & 1 & $550 €$ & $550 €$ & 1 & $550 €$ & $550 €$ \\
\hline Fungicides (kg/ha) & 1 & $326 €$ & $326 €$ & 1 & $326 €$ & $326 €$ \\
\hline Insecticides ( $\mathrm{kg} / \mathrm{ha})$ & 1 & $57 €$ & $57 €$ & 1 & $57 €$ & $57 €$ \\
\hline Herbicides (kg/ha) & 1 & $46 €$ & $46 €$ & 1 & $46 €$ & $46 €$ \\
\hline Botrytis (kg/ha) & 1 & $122 €$ & $122 €$ & 1 & $122 €$ & $122 €$ \\
\hline Fertilizer (kg/ha) & 1 & $140 €$ & $140 €$ & 1 & $140 €$ & $140 €$ \\
\hline Seed Cover Crop (kg/ha) & 0 & $6 €$ & $€$ & 0 & $6 €$ & $-€$ \\
\hline Vine Replacement (1\%/ha) & 38 & $1.44 €$ & $55 €$ & 38 & $1.44 €$ & $55 €$ \\
\hline Material Maintenance & 1 & $19 €$ & $19 €$ & 1 & $19 €$ & $19 €$ \\
\hline Variable Machinery cost (hr/ha) & 73.8 & $15 €$ & $1107 €$ & 73.8 & $15 €$ & $1107 €$ \\
\hline \multicolumn{7}{|c|}{ Factors } \\
\hline Skilled Labour (hr/ha) & 292 & $12.5 €$ & $3649 €$ & 292 & $12.8 €$ & $3733 €$ \\
\hline Unskilled Labour (hr/ha) & 121 & $11.5 €$ & $1390 €$ & 121 & $11.5 €$ & $1390 €$ \\
\hline $\begin{array}{r}\text { Pruning and Canopy Management } \\
\text { (hr/ha) }\end{array}$ & 231 & $12.5 €$ & $2888 €$ & 231 & $12.8 €$ & $2954 €$ \\
\hline Plant Protection (hr/ha) & 18 & $12.5 €$ & $230 €$ & 18 & $12.8 €$ & $235 €$ \\
\hline Soil Management (hr/ha) & 43 & $12.5 €$ & $531 €$ & 43 & $12.8 €$ & $544 €$ \\
\hline Harvesting (hr/ha) & 121 & $11.5 €$ & $1390 €$ & 121 & $11.5 €$ & $1390 €$ \\
\hline Capital/ Fix cost & & & $2368 €$ & & & $2368 €$ \\
\hline Working Capital & $0.18 \%$ & $7270 €$ & $13 €$ & $0.18 \%$ & $7355 €$ & $13 €$ \\
\hline Insurance & 1 & $360 €$ & $360 €$ & 1 & $360 €$ & $360 €$ \\
\hline Annuity vineyard 30 years (ha) & 1 & $1256 €$ & $1256 €$ & 1 & $1256 €$ & $1256 €$ \\
\hline Machinery (ha) & 1 & $738 €$ & $738 €$ & 1 & $738 €$ & $738 €$ \\
\hline Land (ha) & 1 & $700 €$ & $700 €$ & 1 & $500 €$ & $500 €$ \\
\hline \multicolumn{7}{|c|}{ Output } \\
\hline Subsidies (€/ha) & & & $2365 €$ & & & $-€$ \\
\hline Direct support & 1 & $1704 €$ & $1704 €$ & & $-€$ & $-€$ \\
\hline Other support & 1 & $661 \epsilon$ & $661 €$ & & $-€$ & $-\epsilon$ \\
\hline Yield (kg/ha) & 9000 & $0.90 €$ & $8100 €$ & 9000 & $0.90 €$ & $8100 €$ \\
\hline Total Revenue & & & $10465 €$ & & & $8100 €$ \\
\hline Variable Costs & & & $6910 €$ & & & $6995 €$ \\
\hline Total Cost (excl. land) & & & $9277 €$ & & & $9362 €$ \\
\hline Profit (excl. land) & & & $1188 €$ & & & $-1262 €$ \\
\hline Net Profit (incl. Land \& erosion) & & & $488 €$ & & & $-1762 €$ \\
\hline
\end{tabular}

Table Appendix C-2: Basic PAM and Parameters Austria

\begin{tabular}{|c|c|c|c|c|c|c|c|}
\hline $\begin{array}{c}\text { BASIC PAM } \\
\text { AUSTRIA }\end{array}$ & Revenue & $\begin{array}{l}\text { Tradable } \\
\text { Inputs }\end{array}$ & Labour & $\begin{array}{c}\text { Domestic } \\
\text { Capital }\end{array}$ & $\begin{array}{l}\text { sources } \\
\text { Land }\end{array}$ & Erosion & Profits \\
\hline Private & $10465 €$ & $1871 €$ & $5039 €$ & $2368 €$ & $700 €$ & $-€$ & $488 €$ \\
\hline Social & $8100 €$ & $1871 €$ & $5124 €$ & $2368 €$ & $500 €$ & $-€$ & $-1762 €$ \\
\hline Divergence & $2365 €$ & $-€$ & $-85 €$ & $-0 €$ & $200 €$ & $-€$ & $2250 €$ \\
\hline NPCO & NPCI & EPC & SCB & PCB & DRC & PCR & \\
\hline 1.29 & 1.00 & 1.38 & 1.22 & 0.95 & 1.28 & 0.94 & \\
\hline
\end{tabular}


Table Appendix C-3: CT (Case A) Budget Austria

\begin{tabular}{|c|c|c|c|c|c|c|}
\hline CT (CASE A) BUDGET AUSTRIA & Quantity & $\begin{array}{l}\text { Private } \\
\text { Price/ } \\
\text { Quantity }\end{array}$ & $€ /$ ha & Quantity & $\begin{array}{c}\text { Social } \\
\text { Price/ } \\
\text { Quantity }\end{array}$ & $€ /$ ha \\
\hline \multicolumn{7}{|c|}{ Tradables } \\
\hline Chemicals (kg/ha) & 1 & $550 €$ & $550 €$ & 1 & $550 €$ & $550 €$ \\
\hline Fungicides (kg/ha) & 1 & $326 €$ & $326 €$ & 1 & $326 €$ & $326 €$ \\
\hline Insecticides ( $\mathrm{kg} / \mathrm{ha}$ ) & 1 & $57 €$ & $57 €$ & 1 & $57 €$ & $57 €$ \\
\hline Herbicides (kg/ha) & 1 & $46 €$ & $46 €$ & 1 & $46 €$ & $46 €$ \\
\hline Botrytis (kg/ha) & 1 & $122 €$ & $122 \epsilon$ & 1 & $122 €$ & $122 \epsilon$ \\
\hline Fertilizer (kg/ha) & 1 & $140 €$ & $140 €$ & 1 & $140 €$ & $140 €$ \\
\hline Seed Cover Crop (kg/ha) & 0 & $6 €$ & $-€$ & 0 & $6 €$ & $-€$ \\
\hline Vine Replacement (1\%/ha) & 38 & $1.44 €$ & $55 €$ & 38 & $1.44 €$ & $55 €$ \\
\hline Material Maintenance & 1 & $19 €$ & $19 €$ & 1 & $19 €$ & $19 €$ \\
\hline Variable Machinery cost (hr/ha) & 73.8 & $15 €$ & $1107 €$ & 73.8 & $15 €$ & $1107 €$ \\
\hline \multicolumn{7}{|c|}{ Factors } \\
\hline Skilled Labour (hr/ha) & 292 & $12.5 €$ & $3649 €$ & 292 & $12.8 €$ & $3733 €$ \\
\hline $\begin{array}{l}\text { Unskilled Labour (hr/ha) } \\
\quad \text { Pruning and Canopy Management }\end{array}$ & 121 & $11.5 €$ & $1390 €$ & 121 & $11.5 €$ & $1390 €$ \\
\hline (hr/ha) & 231 & $12.5 €$ & $2888 €$ & 231 & $12.8 €$ & $2954 €$ \\
\hline Plant Protection (hr/ha) & 18 & $12.5 €$ & $230 €$ & 18 & $12.8 €$ & $235 €$ \\
\hline Soil Management (hr/ha) & 43 & $12.5 €$ & $531 €$ & 43 & $12.8 €$ & $544 €$ \\
\hline Harvesting $(h r / h a)$ & 121 & $11.5 €$ & $1390 €$ & 121 & $11.5 €$ & $1390 €$ \\
\hline Capital/ Fix cost & & & $2368 €$ & & & $2368 €$ \\
\hline Working Capital & $0.18 \%$ & $7270 €$ & $13 €$ & $0.18 \%$ & $7355 €$ & $13 €$ \\
\hline Insurance & 1 & $360 €$ & $360 €$ & 1 & $360 €$ & $360 €$ \\
\hline Annuity vineyard 30 years (ha) & 1 & $1256 €$ & $1256 €$ & 1 & $1256 €$ & $1256 €$ \\
\hline Machinery (ha) & 1 & $738 €$ & $738 €$ & 1 & $738 €$ & $738 €$ \\
\hline Land (ha) & 1 & $700 €$ & $700 €$ & 1 & $500 €$ & $500 €$ \\
\hline \multicolumn{7}{|c|}{ Erosion costs } \\
\hline \multicolumn{7}{|l|}{ on side costs } \\
\hline (PC) private damage & 9.7 & $2 €$ & $19 €$ & 9.7 & $2 €$ & $19 €$ \\
\hline (MC) private repair/mitigation & 9.7 & $1 €$ & $10 €$ & 9.7 & $1 €$ & $10 €$ \\
\hline off side costs & & & & & & \\
\hline (SC) Social damage & & & $-€$ & 9.7 & $25 €$ & $243 €$ \\
\hline (DC) damage avoidance & & & $-€$ & 9.7 & $7 €$ & $68 €$ \\
\hline \multicolumn{7}{|l|}{ Nonmarket welfare impacts } \\
\hline $\begin{array}{r}\text { Biodiversity } \\
\text { Aesthetic Value }\end{array}$ & & & $-€$ & & & $-€$ \\
\hline \multicolumn{7}{|c|}{ Output } \\
\hline Subsidies ( $€ / \mathrm{ha})$ & & & $2365 €$ & & & $-€$ \\
\hline Direct support & 1 & $1704 €$ & $1704 €$ & & $-\epsilon$ & $-\epsilon$ \\
\hline Other support & 1 & $661 €$ & $661 €$ & & $-€$ & $-€$ \\
\hline Yield (kg/ha) & 9000 & $0.90 €$ & $8100 €$ & 9000 & $0.90 €$ & $8100 €$ \\
\hline Total Revenue & & & $10465 €$ & & & $8100 €$ \\
\hline Variable Costs & & & $6910 €$ & & & $6995 €$ \\
\hline Total cost (Excl. land \& erosion) & & & $9277 €$ & & & $9362 €$ \\
\hline Total Cost (excl. land) & & & $9307 €$ & & & $9702 €$ \\
\hline Profit (excl. land \& erosion) & & & $1188 €$ & & & $-1262 €$ \\
\hline Profit (excl. land) & & & $1158 €$ & & & $-1602 €$ \\
\hline Net Profit (incl. Land \& erosion) & & & $458 €$ & & & $-2102 €$ \\
\hline
\end{tabular}

Table Appendix C-4: CT (Case A) PAM and Parameters Austria

\begin{tabular}{|c|c|c|c|c|c|c|c|}
\hline \multirow{2}{*}{$\begin{array}{c}\text { CT (CASE A) } \\
\text { PAM } \\
\text { AUSTRIA }\end{array}$} & \multirow[t]{2}{*}{ Revenue } & \multirow{2}{*}{$\begin{array}{l}\text { Tradable } \\
\text { Inputs }\end{array}$} & \multicolumn{4}{|c|}{ Domestic Resources } & \multirow[t]{2}{*}{ Profits } \\
\hline & & & Labour & Capital & Land & Erosion & \\
\hline Private & $10465 €$ & $1871 €$ & $5039 €$ & $2368 €$ & $700 €$ & $29 €$ & $458 €$ \\
\hline Social & $8100 €$ & $1871 €$ & $5124 €$ & $2368 €$ & $500 €$ & $340 €$ & $-2102 €$ \\
\hline Divergence & $2365 €$ & $-€$ & $-85 €$ & $-0 €$ & $200 €$ & $-310 €$ & $2560 €$ \\
\hline NPCO & NPCI & EPC & SCB & PCB & DRC & PCR & \\
\hline 1.29 & 1.00 & 1.38 & 1.26 & 0.96 & 1.34 & 0.95 & \\
\hline
\end{tabular}


Table Appendix C-5: TCC (Case A) Budget Austria

\begin{tabular}{|c|c|c|c|c|c|c|}
\hline TCC (CASE A) BUDGET AUSTRIA & Quantity & $\begin{array}{c}\text { Private } \\
\text { Price/ } \\
\text { Quantity }\end{array}$ & $€ /$ ha & Quantity & $\begin{array}{c}\text { Social } \\
\text { Price/ } \\
\text { Quantity }\end{array}$ & $€ /$ ha \\
\hline \multicolumn{7}{|c|}{ Tradables } \\
\hline Chemicals (kg/ha) & 0.958 & $550 €$ & $527 €$ & 0.958 & $550 €$ & $527 €$ \\
\hline Fungicides (kg/ha) & 1 & $326 €$ & $326 €$ & 1 & $326 €$ & $326 €$ \\
\hline Insecticides (kg/ha) & 1 & $57 €$ & $57 €$ & 1 & $57 €$ & $57 €$ \\
\hline Herbicides (kg/ha) & 0.5 & $46 €$ & $23 €$ & 0.5 & $46 €$ & $23 €$ \\
\hline Botrytis (kg/ha) & 1 & $122 €$ & $122 €$ & 1 & $122 €$ & $122 €$ \\
\hline Fertilizer (kg/ha) & 1 & $140 €$ & $140 €$ & 1 & $140 €$ & $140 €$ \\
\hline Seed Cover Crop (kg/ha) & 15 & $6 €$ & $90 €$ & 15 & $6 €$ & $90 €$ \\
\hline Vine Replacement (1\%/ha) & 38 & $1.44 €$ & $55 €$ & 38 & $1.44 €$ & $55 €$ \\
\hline Material Maintenance & 1 & $19 €$ & $19 €$ & 1 & $19 €$ & $19 €$ \\
\hline Variable Machinery cost (hr/ha) & 76 & $15 €$ & $1137 €$ & 76 & $15 €$ & $1137 €$ \\
\hline \multicolumn{7}{|c|}{ Factors } \\
\hline Skilled Labour (hr/ha) & 294 & $12.5 €$ & $3674 €$ & 294 & $12.8 €$ & $3759 €$ \\
\hline Unskilled Labour (hr/ha) & 121 & $11.5 €$ & $1390 €$ & 121 & $11.50 €$ & $1390 €$ \\
\hline $\begin{array}{r}\text { Pruning and Canopy Management } \\
\text { (hr/ha) }\end{array}$ & 231 & $12.5 €$ & $2888 €$ & 231 & $12.8 €$ & $2954 €$ \\
\hline Plant Protection (hr/ha) & 9 & $12.5 €$ & $118 €$ & 9 & $12.8 €$ & $120 €$ \\
\hline Soil Management (hr/ha) & 54 & $12.5 €$ & $669 €$ & 54 & $12.8 €$ & $684 €$ \\
\hline Harvesting (hr/ha) & 121 & $11.5 €$ & $1390 €$ & 121 & $11.5 €$ & $1390 €$ \\
\hline \multicolumn{7}{|l|}{ Capital/ Fix cost } \\
\hline Working Capital & & & $2368 €$ & & & $2368 €$ \\
\hline Insurance & $0.18 \%$ & $7415 €$ & $13 €$ & $0.18 \%$ & $7500 €$ & $14 €$ \\
\hline Annuity vineyard 30 years (ha) & 1 & $360 €$ & $360 €$ & 1 & $360 €$ & $360 €$ \\
\hline Machinery (ha) & 1 & $1256 €$ & $1256 €$ & 1 & $1256 €$ & $1256 €$ \\
\hline Land (ha) & 1 & $738 €$ & $738 €$ & 1 & $738 €$ & $738 €$ \\
\hline \multicolumn{7}{|c|}{ Erosion costs } \\
\hline \multicolumn{7}{|l|}{ on side costs } \\
\hline$(\mathrm{PC})$ private damage & 4.7 & $2 €$ & $9 €$ & 4.7 & $2 €$ & $9 €$ \\
\hline $\begin{array}{l}(\mathrm{MC}) \text { private repair/mitigation } \\
\text { off side costs }\end{array}$ & 4.7 & $1 €$ & $5 €$ & 4.7 & $1 €$ & $5 €$ \\
\hline (SC) Social damage & & & $-€$ & 4.7 & $25 €$ & $118 €$ \\
\hline (DC) damage avoidance & & & $-€$ & 4.7 & $7 €$ & $33 €$ \\
\hline \multicolumn{7}{|l|}{ Nonmarket welfare impacts } \\
\hline $\begin{array}{r}\text { Biodiversity } \\
\text { Aesthetic Value }\end{array}$ & & & $-€$ & & & $-€$ \\
\hline \multicolumn{7}{|c|}{ Output } \\
\hline Subsidies ( $€ / \mathrm{ha})$ & & & $2365 €$ & & & $-€$ \\
\hline Direct support & 1 & $1704 €$ & $1704 €$ & & $-€$ & $-€$ \\
\hline Other support & 1 & $661 €$ & $661 €$ & & $-€$ & $-€$ \\
\hline Yield (kg/ha) & 9000 & $0.90 €$ & $8100 €$ & 9000 & $0.90 €$ & $8100 €$ \\
\hline Total Revenue & & & $10465 €$ & & & $8100 €$ \\
\hline Variable Costs & & & $7032 €$ & & & $7117 €$ \\
\hline Total cost (Excl. land \& erosion) & & & $9400 €$ & & & $9485 €$ \\
\hline Total Cost (excl. land) & & & $9414 €$ & & & $9650 €$ \\
\hline Profit (excl. land \& erosion) & & & $1065 €$ & & & $-1385 €$ \\
\hline Profit (excl. land) & & & $1051 €$ & & & $-1550 €$ \\
\hline Net Profit (incl. Land \& erosion) & & & $351 €$ & & & $-2050 €$ \\
\hline
\end{tabular}

Table Appendix C-6: TCC (Case A) PAM and Parameters Austria

\begin{tabular}{|c|c|c|c|c|c|c|c|}
\hline $\begin{array}{c}\text { TCC (CASE } \\
\text { A) PAM }\end{array}$ & Revenue & Tradable & \multicolumn{4}{|c|}{ Domestic Resources } & \multirow[t]{2}{*}{ Profits } \\
\hline AUSTRIA & & Inputs & Labour & Capital & Land & Erosion & \\
\hline Private & $10465 €$ & $1968 €$ & $5064 €$ & $2368 €$ & $700 €$ & $14 €$ & $351 €$ \\
\hline Social & $8100 €$ & $1968 €$ & $5149 €$ & $2368 €$ & $500 €$ & $165 €$ & $-2050 €$ \\
\hline Divergence & $2365 €$ & $-€$ & $-85 €$ & $-0 €$ & $200 €$ & $-150 €$ & $2401 €$ \\
\hline NPCO & NPCI & EPC & SCB & PCB & DRC & PCR & \\
\hline 1.29 & 1.00 & 1.39 & 1.25 & 0.97 & 1.33 & 0.96 & \\
\hline
\end{tabular}


Table Appendix C-7: PCC (Case A) Budget Austria

\begin{tabular}{|c|c|c|c|c|c|c|}
\hline PCC (CASE A) BUDGET AUSTRIA & Quantity & $\begin{array}{c}\text { Private } \\
\text { Price/ } \\
\text { Quantity }\end{array}$ & $€ /$ ha & Quantity & $\begin{array}{c}\text { Social } \\
\text { Price/ } \\
\text { Quantity }\end{array}$ & $€ /$ ha \\
\hline \multicolumn{7}{|c|}{ Tradables } \\
\hline Chemicals (kg/ha) & 0.916 & $550 €$ & $504 €$ & 0.916 & $550 €$ & $504 €$ \\
\hline Fungicides (kg/ha) & 1 & $326 €$ & $326 €$ & 1 & $326 €$ & $326 €$ \\
\hline Insecticides ( $\mathrm{kg} / \mathrm{ha})$ & 1 & $57 €$ & $57 €$ & 1 & $57 €$ & $57 €$ \\
\hline Herbicides (kg/ha) & 0 & $46 €$ & $-€$ & 0 & $46 €$ & $-€$ \\
\hline Botrytis (kg/ha) & 1 & $122 €$ & $122 €$ & 1 & $122 €$ & $122 €$ \\
\hline Fertilizer (kg/ha) & 1 & $140 €$ & $140 €$ & 1 & $140 €$ & $140 €$ \\
\hline Seed Cover Crop (kg/ha) & 30 & $6 €$ & $180 €$ & 30 & $6 €$ & $180 €$ \\
\hline Vine Replacement (1\%/ha) & 38 & $1.44 €$ & $55 €$ & 38 & $1.44 €$ & $55 €$ \\
\hline Material Maintenance & 1 & $19 €$ & $19 €$ & 1 & $19 €$ & $19 €$ \\
\hline Variable Machinery cost ( $\mathrm{hr} / \mathrm{ha})$ & 76 & $15 €$ & $1137 €$ & 76 & $15 €$ & $1137 €$ \\
\hline \multicolumn{7}{|c|}{ Factors } \\
\hline Skilled Labour (hr/ha) & 294 & $12.5 €$ & $3669 €$ & 294 & $12.8 €$ & $3754 €$ \\
\hline Unskilled Labour (hr/ha) & 121 & $11.5 €$ & $1390 €$ & 121 & $11.5 €$ & $1390 €$ \\
\hline $\begin{array}{r}\text { Pruning and Canopy Management } \\
\text { (hr/ha) }\end{array}$ & 231 & $12.5 €$ & $2888 €$ & 231 & $12.8 €$ & $2954 €$ \\
\hline Plant Protection (hr/ha) & 0 & $12.5 €$ & $-€$ & 0 & $12.8 €$ & $-€$ \\
\hline Soil Management (hr/ha) & 63 & $12.5 €$ & $781 €$ & 63 & $12.8 €$ & $799 €$ \\
\hline Harvesting (hr/ha) & 121 & $11.5 €$ & $1390 €$ & 121 & $11.5 €$ & $1390 €$ \\
\hline \multicolumn{7}{|l|}{ Capital/ Fix cost } \\
\hline Working Capital & & & $2368 €$ & & & $2368 €$ \\
\hline Insurance & $0.18 \%$ & $7500 €$ & $13 €$ & $0.18 \%$ & $7585 €$ & $14 €$ \\
\hline Annuity vineyard 30 years (ha) & 1 & $360 €$ & $360 €$ & 1 & $360 €$ & $360 €$ \\
\hline Machinery (ha) & 1 & $1256 €$ & $1256 €$ & 1 & $1256 €$ & $1256 €$ \\
\hline Land (ha) & 1 & $738 €$ & $738 €$ & 1 & $738 €$ & $738 €$ \\
\hline \multicolumn{7}{|c|}{ Erosion costs } \\
\hline \multicolumn{7}{|l|}{ on side costs } \\
\hline$(\mathrm{PC})$ private damage & 1.4 & $2 €$ & $3 €$ & 1.4 & $2 €$ & $3 €$ \\
\hline \multirow{2}{*}{\multicolumn{7}{|c|}{ off side costs }} \\
\hline & & & & & & \\
\hline (SC) Social damage & & & $-€$ & 1.4 & $25 €$ & $35 €$ \\
\hline (DC) damage avoidance & & & $-€$ & 1.4 & $7 €$ & $10 €$ \\
\hline \multicolumn{7}{|l|}{ Nonmarket welfare impacts } \\
\hline $\begin{array}{r}\text { Biodiversity } \\
\text { Aesthetic Value }\end{array}$ & & & $-€$ & & & $-€$ \\
\hline \multicolumn{7}{|c|}{ Output } \\
\hline Subsidies (€/ha) & & & $2365 €$ & & & $-€$ \\
\hline Direct support & 1 & $1704 €$ & $1704 €$ & & $-€$ & $-€$ \\
\hline Other support & 1 & $661 €$ & $661 €$ & & $-€$ & $-€$ \\
\hline Yield (kg/ha) & 9000 & $0.90 €$ & $8100 €$ & 9000 & $0.90 €$ & $8100 €$ \\
\hline Total Revenue & & & $10465 €$ & & & $8100 €$ \\
\hline Variable Costs & & & $7094 €$ & & & $7179 €$ \\
\hline Total cost (Excl. land \& erosion) & & & $9462 €$ & & & $9547 €$ \\
\hline Total Cost (excl. land) & & & $9466 €$ & & & $9596 €$ \\
\hline Profit (excl. land \& erosion) & & & $1003 €$ & & & $-1447 €$ \\
\hline Profit (excl. land) & & & $999 €$ & & & $-1496 €$ \\
\hline Net Profit (incl. Land \& erosion) & & & $299 €$ & & & $-1996 €$ \\
\hline
\end{tabular}

Table Appendix C-8: PCC (Case A) PAM and Parameters Austria

\begin{tabular}{|c|c|c|c|c|c|c|c|}
\hline \multirow{2}{*}{$\begin{array}{c}\text { PCC (CASE } \\
\text { A) PAM } \\
\text { AUSTRIA }\end{array}$} & \multirow[t]{2}{*}{ Revenue } & \multirow{2}{*}{$\begin{array}{l}\text { Tradable } \\
\text { Inputs }\end{array}$} & \multicolumn{4}{|c|}{ Domestic Resources } & \multirow[t]{2}{*}{ Profits } \\
\hline & & & Labour & Capital & Land & Erosion & \\
\hline Private & $10465 €$ & $2035 €$ & $5059 €$ & $2368 €$ & $700 €$ & $4 €$ & $299 €$ \\
\hline Social & $8100 €$ & $2035 €$ & $5144 €$ & $2368 €$ & $500 €$ & $49 €$ & $-1996 €$ \\
\hline Divergence & $2365 €$ & $-€$ & $-85 €$ & $-0 €$ & $200 €$ & $-45 €$ & $2295 €$ \\
\hline NPCO & NPCI & EPC & SCB & PCB & DRC & PCR & \\
\hline 1.29 & 1.00 & 1.39 & 1.18 & 0.97 & 1.24 & 0.96 & \\
\hline
\end{tabular}




\section{Appendix D PAM Spain}

Table Appendix D-1: Basic Budget Spain

\begin{tabular}{|c|c|c|c|c|c|c|}
\hline BASIC BUDGET SPAIN & Quantity & $\begin{array}{l}\text { Private } \\
\text { Price/ } \\
\text { 2uantity }\end{array}$ & $€ /$ ha & Quantity & $\begin{array}{c}\text { Social } \\
\text { Price/ } \\
\text { Quantity }\end{array}$ & $€ /$ ha \\
\hline \multicolumn{7}{|c|}{ Tradables } \\
\hline Chemicals (kg/ha) & 1 & $330 €$ & $330 €$ & 1 & $330 €$ & $330 €$ \\
\hline Fungicides (kg/ha) & 76 & $4 €$ & $271 €$ & 76 & $4 €$ & $271 €$ \\
\hline Insecticides (kg/ha) & 1 & $30 €$ & $30 €$ & 1 & $30 €$ & $30 €$ \\
\hline Herbicides (kg/ha) & 5 & $6 €$ & $28 €$ & 5 & $6 €$ & $28 €$ \\
\hline Fertilizer (kg/ha) & 150 & $1 €$ & $150 €$ & 150 & $1 €$ & $150 €$ \\
\hline Seed Cover Crop (kg/ha) & 0 & $0.20 €$ & $-€$ & 0 & $0.20 €$ & $-€$ \\
\hline Vine Replacement (1\%/ha) & 15 & $1 €$ & $15 €$ & 15 & $1 €$ & $15 €$ \\
\hline Material Maintenance & 1 & $20 €$ & $20 €$ & 1 & $20 €$ & $20 €$ \\
\hline Variable Machinery cost $(\mathrm{hr} / \mathrm{ha})$ & 25.2 & $15 €$ & $378 €$ & 25.2 & $15 €$ & $378 €$ \\
\hline \multicolumn{7}{|c|}{ Factors } \\
\hline Skilled Labour (hr/ha) & 106 & $10 €$ & $1060 €$ & 106 & $10 €$ & $1060 €$ \\
\hline Unskilled Labour (hr/ha) & 100 & $9 €$ & $874 €$ & 100 & $9 €$ & $874 €$ \\
\hline $\begin{array}{r}\text { Pruning and Canopy Management } \\
\text { (hr/ha) }\end{array}$ & 90 & $10 €$ & $900 €$ & 90 & $10 €$ & $900 €$ \\
\hline Plant Protection (hr/ha) & 8 & $10 €$ & $80 €$ & 8 & $10 €$ & $80 €$ \\
\hline Soil Management (hr/ha) & 8 & $10 €$ & $80 €$ & 8 & $10 €$ & $80 €$ \\
\hline Harvesting (hr/ha) & 100 & $9 €$ & $874 €$ & 100 & $9 €$ & $874 €$ \\
\hline Capital/ Fix cost & & & $912 €$ & & & $912 €$ \\
\hline Working Capital & $0.20 \%$ & $2827 €$ & $6 €$ & $0.20 \%$ & $2827 €$ & $6 €$ \\
\hline Annuity vineyard 30 years (ha) & 1 & $490 €$ & $490 €$ & 1 & $490 €$ & $490 €$ \\
\hline Machinery (ha) & 1 & $416 €$ & $416 €$ & 1 & $416 €$ & $416 €$ \\
\hline Land (ha) & $20 \%$ & $3450 €$ & $690 €$ & 1 & $1129 €$ & $1129 €$ \\
\hline \multicolumn{7}{|c|}{ Output } \\
\hline Subsidies (€/ha) & & & $429 €$ & & & $-€$ \\
\hline Direct support & 1 & $192 €$ & $192 €$ & & $-€$ & $-€$ \\
\hline Other support & 1 & $237 €$ & $237 €$ & & $-€$ & $-€$ \\
\hline Yield (kg/ha) & 11500 & $0.30 €$ & $3450 €$ & 11500 & $0.30 €$ & $3450 €$ \\
\hline Total Revenue & & & $3879 €$ & & & $3450 €$ \\
\hline Variable Costs & & & $2827 €$ & & & $2827 €$ \\
\hline Total Cost (excl. land) & & & $3738 €$ & & & $3738 €$ \\
\hline Profit (excl. land) & & & $141 €$ & & & $-288 €$ \\
\hline Net Profit (incl. Land \& erosion) & & & $-549 €$ & & & $-1417 €$ \\
\hline
\end{tabular}

Table Appendix D-2: Basic PAM and Parameters Spain

\begin{tabular}{|c|c|c|c|c|c|c|c|}
\hline \multirow{2}{*}{$\begin{array}{c}\text { BASIC PAM } \\
\text { SPAIN }\end{array}$} & \multirow[t]{2}{*}{ Revenue } & \multirow{2}{*}{$\begin{array}{l}\text { Tradable } \\
\text { Inputs }\end{array}$} & \multicolumn{4}{|c|}{ Domestic Resources } & \multirow[t]{2}{*}{ Profits } \\
\hline & & & Labour & Capital & Land & Erosion & \\
\hline Private & $3879 €$ & $893 €$ & $1934 €$ & $912 €$ & $690 €$ & $-€$ & $-549 €$ \\
\hline Social & $3450 €$ & $893 €$ & $1934 €$ & $912 €$ & $1129 €$ & $-€$ & $-1417 €$ \\
\hline Divergence & $429 €$ & $-€$ & $-€$ & $-€$ & $-439 €$ & $-€$ & $868 €$ \\
\hline NPCO & NPCI & EPC & SCB & PCB & DRC & PCR & \\
\hline 1.12 & 1.00 & 1.17 & 1.41 & 1.14 & 1.55 & 1.18 & \\
\hline
\end{tabular}


Table Appendix D-3: CT (Case A) Budget Spain

\begin{tabular}{|c|c|c|c|c|c|c|}
\hline CT (CASE A) BUDGET SPAIN & Quantity & $\begin{array}{l}\text { Private } \\
\text { Price/ } \\
\text { Quantity }\end{array}$ & $€ /$ ha & Quantity & $\begin{array}{l}\text { Social } \\
\text { Price/ } \\
\text { Quantity }\end{array}$ & $€ /$ ha \\
\hline \multicolumn{7}{|c|}{ Tradables } \\
\hline Chemicals (kg/ha) & 1 & $330 €$ & $330 €$ & 1 & $330 €$ & $330 €$ \\
\hline Fungicides (kg/ha) & 76 & $4 €$ & $271 €$ & 76 & $4 €$ & $271 €$ \\
\hline Insecticides ( $\mathrm{kg} / \mathrm{ha}$ ) & 1 & $30 €$ & $30 €$ & 1 & $30 €$ & $30 €$ \\
\hline Herbicides (kg/ha) & 5 & $6 €$ & $28 €$ & 5 & $6 €$ & $28 €$ \\
\hline Fertilizer (kg/ha) & 150 & $1 €$ & $150 €$ & 150 & $1 €$ & $150 €$ \\
\hline Seed Cover Crop (kg/ha) & 0 & $0.20 €$ & $-€$ & 0 & $0.20 €$ & $-€$ \\
\hline Vine Replacement (1\%/ha) & 15 & $1 €$ & $15 €$ & 15 & $1 €$ & $15 €$ \\
\hline Material Maintenance & 1 & $20 €$ & $20 €$ & 1 & $20 €$ & $20 €$ \\
\hline Variable Machinery cost ( $\mathrm{hr} / \mathrm{ha})$ & 25.2 & $15 €$ & $378 €$ & 25.2 & $15 €$ & $378 €$ \\
\hline \multicolumn{7}{|c|}{ Factors } \\
\hline Skilled Labour (hr/ha) & 106 & $10 €$ & $1060 €$ & 106 & $10 €$ & $1060 €$ \\
\hline Unskilled Labour (hr/ha) & 100 & $9 €$ & $874 €$ & 100 & $9 €$ & $874 €$ \\
\hline $\begin{array}{r}\text { Pruning and Canopy Management } \\
\text { (hr/ha) }\end{array}$ & 90 & $10 €$ & $900 €$ & 90 & $10 €$ & $900 €$ \\
\hline Plant Protection (hr/ha) & 8 & $10 €$ & $80 €$ & 8 & $10 €$ & $80 €$ \\
\hline Soil Management (hr/ha) & 8 & $10 €$ & $80 €$ & 8 & $10 €$ & $80 €$ \\
\hline Harvesting (hr/ha) & 100 & $9 €$ & $874 €$ & 100 & $9 €$ & $874 €$ \\
\hline Capital/ Fix cost & & & $912 €$ & & & $912 €$ \\
\hline Working Capital & $0.20 \%$ & $2827 €$ & $6 €$ & $0.20 \%$ & $2827 €$ & $6 €$ \\
\hline Annuity vineyard 30 years (ha) & 1 & $490 €$ & $490 €$ & 1 & $490 €$ & $490 €$ \\
\hline Machinery (ha) & 1 & $416 €$ & $416 €$ & 1 & $416 €$ & $416 €$ \\
\hline Land (ha) & $20 \%$ & $3450 €$ & $690 €$ & 1 & $1129 €$ & $1129 €$ \\
\hline \multicolumn{7}{|c|}{ Erosion costs } \\
\hline \multicolumn{7}{|l|}{ on side costs } \\
\hline$(\mathrm{PC})$ private damage & 7.14 & $2 €$ & $14 €$ & 7.14 & $2 €$ & $14 €$ \\
\hline $\begin{array}{l}(\mathrm{MC}) \text { private repair/mitigation } \\
\text { off side costs }\end{array}$ & 7.14 & $1 €$ & $7 €$ & 7.14 & $1 €$ & $7 €$ \\
\hline (SC) Social damage & 7.14 & $-€$ & $-€$ & 7.14 & $25 €$ & $179 €$ \\
\hline $\begin{array}{l}\text { (DC) damage avoidance } \\
\text { Nonmarket }\end{array}$ & 7.14 & $-€$ & $-€$ & 7.14 & $7 €$ & $50 €$ \\
\hline $\begin{array}{r}\text { Nonmarket Welrare Impacts } \\
\text { Biodiversity } \\
\text { Aesthetic Value }\end{array}$ & & & $-€$ & & & $-€$ \\
\hline \multicolumn{7}{|c|}{ Output } \\
\hline Subsidies (€/ha) & & & $429 €$ & & & $-€$ \\
\hline Direct support & 1 & $192 €$ & $192 €$ & & $-€$ & $-€$ \\
\hline Other support & 1 & $237 €$ & $237 €$ & & $-€$ & $-€$ \\
\hline Yield (kg/ha) & 11500 & $0.30 €$ & $3450 €$ & 11500 & $0.30 €$ & $3450 €$ \\
\hline Total Revenue & & & $3879 €$ & & & $3450 €$ \\
\hline Variable Costs & & & $2827 €$ & & & $2827 €$ \\
\hline Total cost (Excl. land \& erosion) & & & $3738 €$ & & & $3738 €$ \\
\hline Total Cost (excl. land) & & & $3760 €$ & & & $3988 €$ \\
\hline Profit (excl. land \& erosion) & & & $141 €$ & & & $-288 €$ \\
\hline Profit (excl. land) & & & $119 €$ & & & $-538 €$ \\
\hline Net Profit (incl. Land \& erosion) & & & $-571 €$ & & & $-1667 €$ \\
\hline
\end{tabular}

Table Appendix D-4: CT (Case A) PAM and Parameters Spain

\begin{tabular}{|c|c|c|c|c|c|c|c|}
\hline \multirow{2}{*}{$\begin{array}{l}\text { CT (CASE A) } \\
\text { PAM SPAIN }\end{array}$} & \multirow[t]{2}{*}{ Revenue } & \multirow{2}{*}{$\begin{array}{l}\text { Tradable } \\
\text { Inputs }\end{array}$} & \multicolumn{4}{|c|}{ Domestic Resources } & \multirow[t]{2}{*}{ Profits } \\
\hline & & & Labour & Capital & Land & Erosion & \\
\hline Private & $3879 €$ & $893 €$ & $1934 €$ & $912 €$ & $690 €$ & $21 €$ & $-571 €$ \\
\hline Social & $3450 €$ & $893 €$ & $1934 €$ & $912 €$ & $1129 €$ & $250 €$ & $-1667 €$ \\
\hline Divergence & $429 €$ & $-€$ & $-€$ & $-€$ & $-439 €$ & $-228 €$ & $1096 €$ \\
\hline NPCO & NPCI & EPC & SCB & PCB & DRC & PCR & \\
\hline 1.12 & 1.00 & 1.17 & 1.48 & 1.15 & 1.65 & 1.19 & \\
\hline
\end{tabular}


Table Appendix D-5: TCC (Case A) Budget Spain

\begin{tabular}{|c|c|c|c|c|c|c|}
\hline TCC (CASE A) BUDGET SPAIN & Quantity & $\begin{array}{c}\text { Private } \\
\text { Price/ } \\
\text { Quantity }\end{array}$ & $€ /$ ha & Quantity & $\begin{array}{c}\text { Social } \\
\text { Price/ } \\
\text { Quantity }\end{array}$ & $€ /$ ha \\
\hline \multicolumn{7}{|c|}{ Tradables } \\
\hline Chemicals (kg/ha) & 1 & $330 €$ & $330 €$ & 1 & $330 €$ & $330 €$ \\
\hline Fungicides (kg/ha) & 76 & $4 €$ & $271 €$ & 76 & $4 €$ & $271 €$ \\
\hline Insecticides (kg/ha) & 1 & $30 €$ & $30 €$ & 1 & $30 €$ & $30 €$ \\
\hline Herbicides (kg/ha) & 5 & $6 €$ & $28 €$ & 5 & $6 €$ & $28 €$ \\
\hline Fertilizer (kg/ha) & 150 & $1 €$ & $150 €$ & 150 & $1 €$ & $150 €$ \\
\hline Seed Cover Crop (kg/ha) & 80 & $0.20 €$ & $16 €$ & 80 & $0.20 €$ & $16 €$ \\
\hline Vine Replacement (1\%/ha) & 15 & $1 €$ & $15 €$ & 15 & $1 €$ & $15 €$ \\
\hline Material Maintenance & 1 & $20 €$ & $20 €$ & 1 & $20 €$ & $20 €$ \\
\hline Variable Machinery cost (hr/ha) & 27.2 & $15 €$ & $408 €$ & 27.2 & $15 €$ & $408 €$ \\
\hline \multicolumn{7}{|c|}{ Factors } \\
\hline Skilled Labour (hr/ha) & 108 & $10 €$ & $1080 €$ & 108 & $10 €$ & $1080 €$ \\
\hline Unskilled Labour (hr/ha) & 100 & $9 €$ & $874 €$ & 100 & $9 €$ & $874 €$ \\
\hline $\begin{array}{r}\text { Pruning and Canopy Management } \\
\text { (hr/ha) }\end{array}$ & 90 & $10 €$ & $900 €$ & 90 & $10 €$ & $900 €$ \\
\hline Plant Protection (hr/ha) & 8 & $10 €$ & $80 €$ & 8 & $10 €$ & $80 €$ \\
\hline Soil Management (hr/ha) & 10 & $10 €$ & $100 €$ & 10 & $10 €$ & $100 €$ \\
\hline Harvesting (hr/ha) & 100 & $9 €$ & $874 €$ & 100 & $9 €$ & $874 €$ \\
\hline Capital/ Fix cost & & & $912 €$ & & & $912 €$ \\
\hline Working Capital & $0.20 \%$ & $2893 €$ & $6 €$ & $0.20 \%$ & $2893 €$ & $6 €$ \\
\hline Annuity vineyard 30 years (ha) & 1 & $490 €$ & $490 €$ & 1 & $490 €$ & $490 €$ \\
\hline Machinery (ha) & 1 & $416 €$ & $416 €$ & 1 & $416 €$ & $416 €$ \\
\hline Land (ha) & $20 \%$ & $3450 €$ & $690 €$ & 1 & $1129 €$ & $1129 €$ \\
\hline \multicolumn{7}{|c|}{ Erosion costs } \\
\hline \multicolumn{7}{|l|}{ on side costs } \\
\hline$(\mathrm{PC})$ private damage & 9.53 & $2 €$ & $19 €$ & 9.53 & $2 €$ & $19 €$ \\
\hline $\begin{array}{l}\text { (MC) private repair/mitigation } \\
\text { off side costs }\end{array}$ & 9.53 & $1 €$ & $10 €$ & 9.53 & $1 €$ & $10 €$ \\
\hline (SC) Social damage & 9.53 & $-€$ & $-€$ & 9.53 & $25 €$ & $238 €$ \\
\hline (DC) damage avoidance & 9.53 & $-€$ & $-€$ & 9.53 & $7 €$ & $67 €$ \\
\hline \multicolumn{7}{|l|}{ Nonmarket welfare impacts } \\
\hline $\begin{array}{r}\text { Biodiversity } \\
\text { Aesthetic Value }\end{array}$ & & & $-€$ & & & $-€$ \\
\hline \multicolumn{7}{|c|}{ Output } \\
\hline Subsidies (€/ha) & & & $429 €$ & & & $-€$ \\
\hline Direct support & 1 & $192 €$ & $192 €$ & & $-€$ & $-€$ \\
\hline Other support & 1 & $237 €$ & $237 €$ & & $-€$ & $-€$ \\
\hline Yield (kg/ha) & 11500 & $0.30 €$ & $3450 €$ & 11500 & $0.30 €$ & $3450 €$ \\
\hline Total Revenue & & & $3879 €$ & & & $3450 €$ \\
\hline Variable Costs & & & $2893 €$ & & & $2893 €$ \\
\hline Total cost (Excl. land \& erosion) & & & $3805 €$ & & & $3805 €$ \\
\hline Total Cost (excl. land) & & & $3833 €$ & & & $4138 €$ \\
\hline Profit (excl. land \& erosion) & & & $74 €$ & & & $-355 €$ \\
\hline Profit (excl. land) & & & $46 €$ & & & $-688 €$ \\
\hline Net Profit (incl. Land \& erosion) & & & $-644 €$ & & & $-1817 €$ \\
\hline
\end{tabular}

Table Appendix D-6: TCC (Case A) PAM and Parameters Spain

\begin{tabular}{|c|c|c|c|c|c|c|c|}
\hline \multirow{2}{*}{$\begin{array}{l}\text { TCC (CASE A) } \\
\text { PAM SPAIN }\end{array}$} & \multirow[t]{2}{*}{ Revenue } & \multirow{2}{*}{$\begin{array}{l}\text { Tradable } \\
\text { Inputs }\end{array}$} & \multicolumn{4}{|c|}{ Domestic Resources } & \multirow[t]{2}{*}{ Profits } \\
\hline & & & Labour & Capital & Land & Erosion & \\
\hline Private & $3879 €$ & $939 €$ & $1954 €$ & $912 €$ & $690 €$ & $29 €$ & $-644 €$ \\
\hline Social & $3450 €$ & $939 €$ & $1954 €$ & $912 €$ & $1129 €$ & $334 €$ & $-1817 €$ \\
\hline Divergence & $429 €$ & $-€$ & $-€$ & $-€$ & $-439 €$ & $-305 €$ & $1173 €$ \\
\hline NPCO & NPCI & EPC & SCB & PCB & DRC & PCR & \\
\hline 1.12 & 1.00 & 1.17 & 1.53 & 1.17 & 1.72 & 1.22 & \\
\hline
\end{tabular}


Table Appendix D-7: PCC (Case A) Budget Spain

\begin{tabular}{|c|c|c|c|c|c|c|}
\hline PCC (CASE A) BUDGET SPAIN & Quantity & $\begin{array}{c}\text { Private } \\
\text { Price/ } \\
\text { Quantity }\end{array}$ & $€ /$ ha & Quantity & $\begin{array}{c}\text { Social } \\
\text { Price/ } \\
\text { Quantity }\end{array}$ & $€ /$ ha \\
\hline \multicolumn{7}{|c|}{ Tradables } \\
\hline Chemicals (kg/ha) & 0.958 & $330 €$ & $316 €$ & 0.958 & $330 €$ & $316 €$ \\
\hline Fungicides (kg/ha) & 76 & $4 €$ & $271 €$ & 76 & $4 €$ & $271 €$ \\
\hline Insecticides ( $\mathrm{kg} / \mathrm{ha}$ ) & 1 & $30 €$ & $30 €$ & 1 & $30 €$ & $30 €$ \\
\hline Herbicides (kg/ha) & 2.5 & $6 €$ & $14 €$ & 2.5 & $6 €$ & $14 €$ \\
\hline Fertilizer (kg/ha) & 150 & $1 €$ & $150 €$ & 150 & $1 €$ & $150 €$ \\
\hline Seed Cover Crop (kg/ha) & 1 & $90 €$ & $90 €$ & 1 & $90 €$ & $90 €$ \\
\hline Vine Replacement (1\%/ha) & 15 & $1 €$ & $15 €$ & 15 & $1 €$ & $15 €$ \\
\hline Material Maintenance & 1 & $20 €$ & $20 €$ & 1 & $20 €$ & $20 €$ \\
\hline Variable Machinery cost (hr/ha) & 27.2 & $15 €$ & $408 €$ & 27.2 & $15 €$ & $408 €$ \\
\hline \multicolumn{7}{|c|}{ Factors } \\
\hline Skilled Labour (hr/ha) & 108 & $10 €$ & $1080 €$ & 108 & $10 €$ & $1080 €$ \\
\hline Unskilled Labour (hr/ha) & 100 & $9 €$ & $874 €$ & 100 & $9 €$ & $874 €$ \\
\hline $\begin{array}{r}\text { Pruning and Canopy Management } \\
\text { (hr/ha) }\end{array}$ & 90 & $10 €$ & $900 €$ & 90 & $10 €$ & $900 €$ \\
\hline Plant Protection (hr/ha) & 4 & $10 €$ & $40 €$ & 4 & $10 €$ & $40 €$ \\
\hline Soil Management (hr/ha) & 14 & $10 €$ & $140 €$ & 14 & $10 €$ & $140 €$ \\
\hline Harvesting (hr/ha) & 100 & $9 €$ & $874 €$ & 100 & $9 €$ & $874 €$ \\
\hline Capital/ Fix cost & & & $912 €$ & & & $912 €$ \\
\hline Working Capital & $0.20 \%$ & $2953 €$ & $6 €$ & $0.20 \%$ & $2953 €$ & $6 €$ \\
\hline Annuity vineyard 30 years (ha) & 1 & $490 €$ & $490 €$ & 1 & $490 €$ & $490 €$ \\
\hline Machinery (ha) & 1 & $416 €$ & $416 €$ & 1 & $416 €$ & $416 €$ \\
\hline Land (ha) & $20 \%$ & $3450 €$ & $690 €$ & 1 & $1129 €$ & $1129 €$ \\
\hline \multicolumn{7}{|c|}{ Erosion costs } \\
\hline \multicolumn{7}{|l|}{ on side costs } \\
\hline$(\mathrm{PC})$ private damage & 1.64 & $2 €$ & $3 €$ & 1.64 & $2 €$ & $3 €$ \\
\hline $\begin{array}{l}\text { (MC) private repair/mitigation } \\
\text { off side costs }\end{array}$ & 1.64 & $1 €$ & $2 €$ & 1.64 & $1 €$ & $2 €$ \\
\hline (SC) Social damage & 1.64 & $-€$ & $-€$ & 1.64 & $25 €$ & $41 €$ \\
\hline (DC) damage avoidance & 1.64 & $-€$ & $-€$ & 1.64 & $7 €$ & $11 €$ \\
\hline \multicolumn{7}{|l|}{ Nonmarket welfare impacts } \\
\hline $\begin{array}{r}\text { Biodiversity } \\
\text { Aesthetic Value }\end{array}$ & & & $-€$ & & & $-€$ \\
\hline \multicolumn{7}{|c|}{ Output } \\
\hline Subsidies (€/ha) & & & $429 €$ & & & $-€$ \\
\hline Direct support & 1 & $192 €$ & $192 €$ & & $-€$ & $-€$ \\
\hline Other support & 1 & $237 €$ & $237 €$ & & $-€$ & $-€$ \\
\hline Yield (kg/ha) & 11500 & $0.30 €$ & $3450 €$ & 11500 & $0.30 €$ & $3450 €$ \\
\hline Total Revenue & & & $3879 €$ & & & $3450 €$ \\
\hline Variable Costs & & & $2953 €$ & & & $2953 €$ \\
\hline Total cost (Excl. land \& erosion) & & & $3864 €$ & & & $3864 €$ \\
\hline Total Cost (excl. land) & & & $3869 €$ & & & $3922 €$ \\
\hline Profit (excl. land \& erosion) & & & $15 €$ & & & $-414 €$ \\
\hline Profit (excl. land) & & & $10 €$ & & & $-472 €$ \\
\hline Net Profit (incl. Land \& erosion) & & & $-680 €$ & & & $-1601 €$ \\
\hline
\end{tabular}

Table Appendix D-8: PCC (Case A) PAM and Parameters Spain

\begin{tabular}{|c|c|c|c|c|c|c|c|}
\hline \multirow{2}{*}{$\begin{array}{l}\text { PCC (CASE A) } \\
\text { PAM SPAIN }\end{array}$} & \multirow[t]{2}{*}{ Revenue } & \multirow{2}{*}{$\begin{array}{l}\text { Tradable } \\
\text { Inputs }\end{array}$} & \multicolumn{4}{|c|}{ Domestic Resources } & \multirow[t]{2}{*}{ Profits } \\
\hline & & & Labour & Capital & Land & Erosion & \\
\hline Private & $3879 €$ & $999 €$ & $1954 €$ & $912 €$ & $690 €$ & $5 €$ & $-680 €$ \\
\hline Social & $3450 €$ & $999 €$ & $1954 €$ & $912 €$ & $1129 €$ & $57 €$ & $-1601 €$ \\
\hline Divergence & $429 €$ & $-€$ & $-€$ & $-€$ & $-439 €$ & $-52 €$ & $920 €$ \\
\hline NPCO & NPCI & EPC & SCB & PCB & DRC & PCR & \\
\hline 1.12 & 1.00 & 1.18 & 1.46 & 1.18 & 1.65 & 1.24 & \\
\hline
\end{tabular}




\section{Appendix E Costs for cover crops}

Table Appendix E-1: Costs for Cover Crops in Montilla-Moriles

\begin{tabular}{crr} 
& TCC & PCC \\
\hline Total Costs & $\mathbf{6 6} €$ & $\mathbf{1 2 6} €$ \\
\hline 2 h Tractor & $30 €$ & $30 €$ \\
2 h Labour & $20 €$ & $20 €$ \\
Seeds & $16 €$ & $90 €$ \\
\hline Herbicide reduction & - & $-14 €$
\end{tabular}

Table Appendix E-2: Costs for Cover Crops in Carnuntum

\begin{tabular}{crr} 
& TCC & PCC \\
\hline Total Costs & $\mathbf{1 2 2} €$ & $\mathbf{1 8 9} €$ \\
\hline 2 h Tractor & $30 €$ & $30 €$ \\
2 h Labour & $25 €$ & $25 €$ \\
Seeds & $90 €$ & $180 €$ \\
\hline Herbicide reduction & $-23 €$ & $-46 €$
\end{tabular}




\section{Appendix F PAM France}

Table Appendix F-1: Basic Budget France

\begin{tabular}{|c|c|c|c|c|c|c|}
\hline BASIC BUDGET FRANCE & Quantity & $\begin{array}{c}\text { Private } \\
\text { Price/ } \\
\text { Quantity }\end{array}$ & $€ /$ ha & Quantity & $\begin{array}{c}\text { Social } \\
\text { Price/ } \\
\text { Quantity }\end{array}$ & $€ /$ ha \\
\hline \multicolumn{7}{|c|}{ Tradables } \\
\hline Chemicals (kg/ha) & 1 & $458 €$ & $458 €$ & 1 & $330 €$ & $330 €$ \\
\hline Fungicides (kg/ha) & 1 & $422 €$ & $422 €$ & 76 & $4 €$ & $271 €$ \\
\hline Insecticides (kg/ha) & 1 & $26 €$ & $26 €$ & 1 & $30 €$ & $30 €$ \\
\hline Herbicides $(\mathrm{kg} / \mathrm{ha})$ & 1 & $10 €$ & $10 €$ & 5 & $6 €$ & $28 €$ \\
\hline Fertilizer (kg/ha) & 1 & $219 €$ & $219 €$ & 150 & $1 €$ & $150 €$ \\
\hline Seed Cover Crop (kg/ha) & 0 & $20 €$ & $€$ & 0 & $0.20 €$ & $€$ \\
\hline Vine Replacement (1\%/ha) & 15 & $1 €$ & $15 €$ & 15 & $1 €$ & $15 €$ \\
\hline Material Maintenance & 1 & $20 €$ & $20 €$ & 1 & $20 €$ & $20 €$ \\
\hline Variable Machinery cost (hr/ha) & 1 & $419 €$ & $419 €$ & 1 & $378 €$ & $378 €$ \\
\hline \multicolumn{7}{|c|}{ Factors } \\
\hline Skilled Labour (hr/ha) & & & & 106 & $10 €$ & $1060 €$ \\
\hline Unskilled Labour (hr/ha) & 1 & $3400 €$ & $3400 €$ & 100 & $8.74 €$ & $874 €$ \\
\hline Capital/ Fix cost & & & $915 €$ & & & $912 €$ \\
\hline Working Capital & $0.20 \%$ & $4531 €$ & $9 €$ & $0.20 \%$ & $2827 €$ & $6 €$ \\
\hline Annuity vineyard 30 years (ha) & 1 & $490 €$ & $490 €$ & 1 & $490 €$ & $490 €$ \\
\hline Machinery (ha) & 1 & $416 €$ & $416 €$ & 1 & $416 €$ & $416 €$ \\
\hline Land rent (ha) & $20 \%$ & $8280 €$ & $1656 €$ & 1 & $1129 €$ & $1129 €$ \\
\hline \multicolumn{7}{|c|}{ Output } \\
\hline Subsidies (€/ha) & & & $1102 €$ & & & $€$ \\
\hline Direct support & 1 & $458 €$ & $458 €$ & & $€$ & $€$ \\
\hline Other support & 1 & $644 €$ & $644 €$ & & $€$ & $€$ \\
\hline Yield $(\mathrm{kg} / \mathrm{ha})$ & 10350 & $0.80 €$ & $8280 €$ & 10350 & $0.80 €$ & $8280 €$ \\
\hline Total Revenue & & & $9382 €$ & & & $8280 €$ \\
\hline Variable Costs & & & $4531 €$ & & & $2827 €$ \\
\hline Total Cost (excl. land) & & & $5446 €$ & & & $3738 €$ \\
\hline Profit (excl. land) & & & $3936 €$ & & & $4542 €$ \\
\hline Net Profit (incl. Land) & & & $2280 €$ & & & $3413 €$ \\
\hline
\end{tabular}

Table Appendix F-2: Basic PAM and Parameters France

\begin{tabular}{|c|c|c|c|c|c|c|}
\hline \multirow{2}{*}{$\begin{array}{l}\text { BASIC PAM } \\
\text { FRANCE }\end{array}$} & \multirow[t]{2}{*}{ Revenue } & \multirow{2}{*}{$\begin{array}{l}\text { Tradable } \\
\text { Inputs }\end{array}$} & \multicolumn{3}{|c|}{ Domestic Resources } & \multirow[t]{2}{*}{ Profits } \\
\hline & & & Labour & Capital & Land & \\
\hline Private & $9382 €$ & $1131 €$ & $3400 €$ & $915 €$ & $1656 €$ & $2280 €$ \\
\hline Social & $8280 €$ & $893 €$ & $1934 €$ & $912 €$ & $1129 €$ & $3413 €$ \\
\hline Divergence & $1102 €$ & $238 €$ & $1466 €$ & $3 €$ & $527 €$ & $-1133 €$ \\
\hline NPCO & NPCI & EPC & SCB & DRC & PCR & \\
\hline 1.13 & 1.27 & 1.12 & 0.59 & 0.54 & 0.72 & \\
\hline
\end{tabular}


Table Appendix F-3: CC Budget France

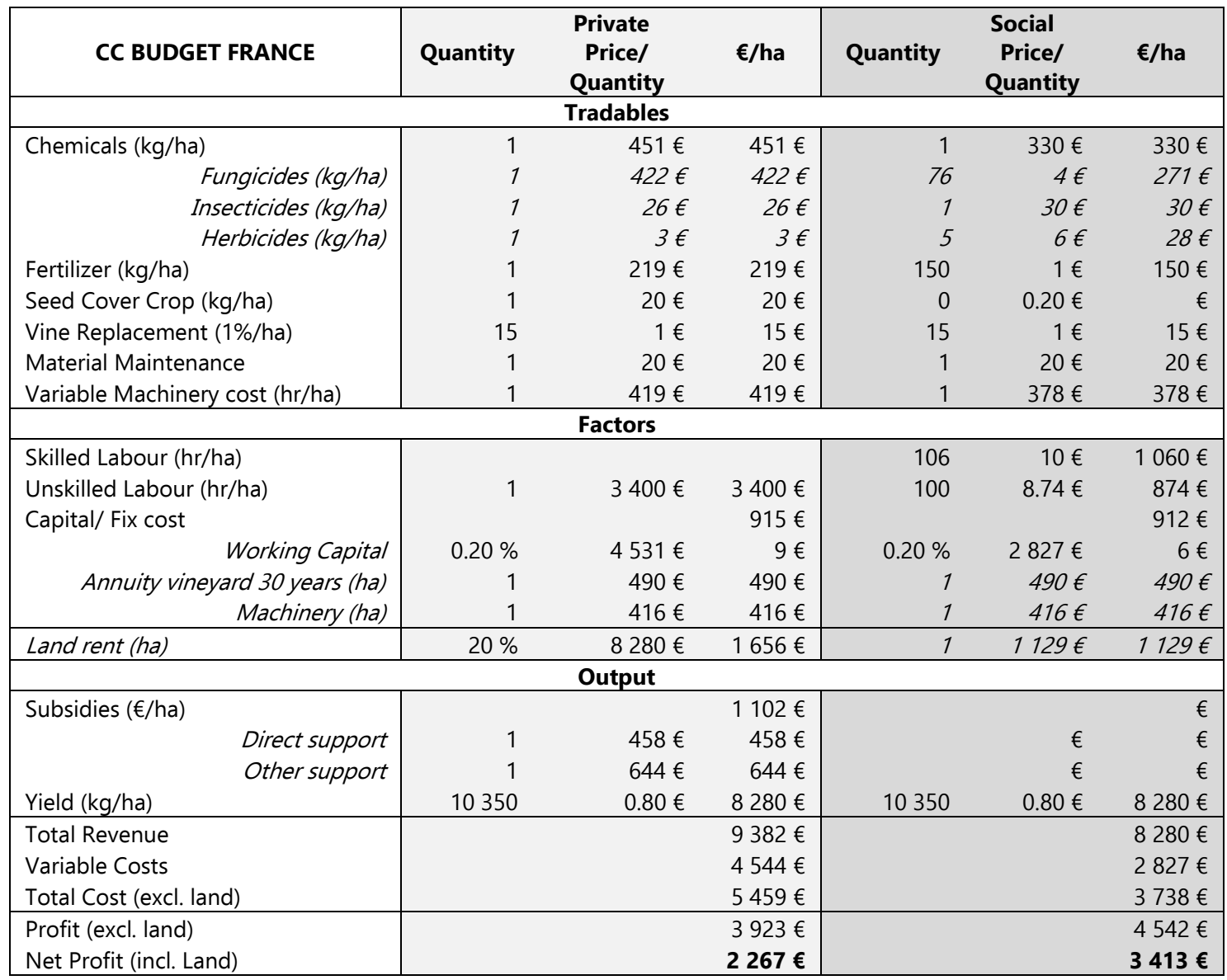

Table Appendix F-4: CC PAM and Parameters France

\begin{tabular}{|c|c|c|c|c|c|c|}
\hline \multirow{2}{*}{$\begin{array}{l}\text { CC PAM } \\
\text { FRANCE }\end{array}$} & \multirow[t]{2}{*}{ Revenue } & \multirow{2}{*}{$\begin{array}{c}\text { Tradable } \\
\text { Inputs }\end{array}$} & \multicolumn{3}{|c|}{ Domestic Resources } & \multirow[t]{2}{*}{ Profits } \\
\hline & & & Labour & Capital & Land & \\
\hline Private & $9382 €$ & $1144 €$ & $3400 €$ & $915 €$ & $1656 €$ & $2267 €$ \\
\hline Social & $8280 €$ & $893 €$ & $1934 €$ & $912 €$ & $1129 €$ & $3413 €$ \\
\hline Divergence & $1102 €$ & $251 €$ & $1466 €$ & $3 €$ & $527 €$ & $-1146 €$ \\
\hline NPCO & NPCI & EPC & SCB & DRC & PCR & \\
\hline 1.13 & 1.28 & 1.12 & 0.59 & 0.54 & 0.72 & \\
\hline
\end{tabular}


Table Appendix F-5: CC and Marketing Budget France

\begin{tabular}{|c|c|c|c|c|c|c|}
\hline $\begin{array}{l}\text { CC and Marketing } \\
\text { BUDGET FRANCE }\end{array}$ & Quantity & $\begin{array}{l}\text { Private } \\
\text { Price/ } \\
\text { Quantity }\end{array}$ & $€ /$ ha & Quantity & $\begin{array}{c}\text { Social } \\
\text { Price/ } \\
\text { Quantity }\end{array}$ & $€ /$ ha \\
\hline \multicolumn{7}{|c|}{ Tradables } \\
\hline Chemicals (kg/ha) & 1 & $451 €$ & $451 €$ & 1 & $330 €$ & $330 €$ \\
\hline Fungicides (kg/ha) & 1 & $422 €$ & $422 €$ & 76 & $4 €$ & $271 €$ \\
\hline Insecticides (kg/ha) & 1 & $26 €$ & $26 €$ & 1 & $30 €$ & $30 €$ \\
\hline Herbicides $(\mathrm{kg} / \mathrm{ha})$ & 1 & $3 €$ & $3 €$ & 5 & $6 €$ & $28 €$ \\
\hline Fertilizer $(\mathrm{kg} / \mathrm{ha})$ & 1 & $219 €$ & $219 €$ & 150 & $1 €$ & $150 €$ \\
\hline Seed Cover Crop (kg/ha) & 1 & $20 €$ & $20 €$ & 0 & $0.20 €$ & $€$ \\
\hline Vine Replacement (1\%/ha) & 15 & $1 €$ & $15 €$ & 15 & $1 €$ & $15 €$ \\
\hline Material Maintenance & 1 & $20 €$ & $20 €$ & 1 & $20 €$ & $20 €$ \\
\hline Variable Machinery cost (hr/ha) & 1 & $419 €$ & $419 €$ & 1 & $378 €$ & $378 €$ \\
\hline \multicolumn{7}{|c|}{ Factors } \\
\hline Skilled Labour (hr/ha) & & & & 106 & $10 €$ & $1060 €$ \\
\hline Unskilled Labour (hr/ha) & 1 & $3400 €$ & $3400 €$ & 100 & $8.74 €$ & $874 €$ \\
\hline Capital/ Fix cost & & & $915 €$ & & & $912 €$ \\
\hline Working Capital & $0.20 \%$ & $4531 €$ & $9 €$ & $0.20 \%$ & $2827 €$ & $6 €$ \\
\hline Annuity vineyard 30 years (ha) & 1 & $490 €$ & $490 €$ & 1 & $490 €$ & $490 €$ \\
\hline Machinery (ha) & 1 & $416 €$ & $416 €$ & 1 & $416 €$ & $416 €$ \\
\hline Land rent (ha) & $20 \%$ & $41400 €$ & $8280 €$ & 1 & $1129 €$ & $1129 €$ \\
\hline \multicolumn{7}{|c|}{ Output } \\
\hline Subsidies (€/ha) & & & $1102 €$ & & & $€$ \\
\hline Direct support & 1 & $458 €$ & $458 €$ & & $€$ & $€$ \\
\hline Other support & 1 & $644 €$ & $644 €$ & & $€$ & $€$ \\
\hline Yield (kg/ha) & 10350 & $4.00 €$ & $41400 €$ & 10350 & $4.00 €$ & $41400 €$ \\
\hline Total Revenue & & & $42502 €$ & & & $41400 €$ \\
\hline Variable Costs & & & $4544 €$ & & & $2827 €$ \\
\hline Total Cost (excl. land) & & & $5459 €$ & & & $3738 €$ \\
\hline Profit (excl. land) & & & $37043 €$ & & & $37662 €$ \\
\hline Net Profit (incl. Land) & & & $28763 €$ & & & $36533 €$ \\
\hline
\end{tabular}

Table Appendix F-6: CC and Marketing PAM and Parameters France

\begin{tabular}{|c|c|c|c|c|c|c|}
\hline \multirow{2}{*}{$\begin{array}{c}\text { CC and } \\
\text { Marketing } \\
\text { PAM FRANCE }\end{array}$} & \multirow[t]{2}{*}{ Revenue } & \multirow{2}{*}{$\begin{array}{l}\text { Tradable } \\
\text { Inputs }\end{array}$} & \multicolumn{3}{|c|}{ Domestic Resources } & \multirow[t]{2}{*}{ Profits } \\
\hline & & & Labour & Capital & Land & \\
\hline Private & $42502 €$ & $1144 €$ & $3400 €$ & $915 €$ & $8280 €$ & $28763 €$ \\
\hline Social & $41400 €$ & $893 €$ & $1934 €$ & $912 €$ & $1129 €$ & $36533 €$ \\
\hline Divergence & $1102 €$ & $251 €$ & $1466 €$ & $3 €$ & $7151 €$ & $-7770 €$ \\
\hline NPCO & NPCI & EPC & SCB & DRC & PCR & \\
\hline 1.03 & 1.28 & 1.02 & 0.12 & 0.10 & 0.30 & \\
\hline
\end{tabular}




\section{Publications}

\section{Peer-reviewed Paper}

Schütte, R., Bergmann, H. (2018). The Attitudes of French and Spanish Winegrowers towards the use of Cover Crops in Vineyards. The Journal of Wine Research

\section{Conference Paper}

Schütte, R., Plaas, E, Gómez, J. A., Guzmán, G. (2019). Profitability of erosion control with cover crops in European vineyards under consideration of environmental costs. Oral presentation at $172^{\text {nd }}$ EAAE Seminar, Brussels, Belgium, $28^{\text {th }}-29^{\text {th }}$ May

Schütte, R., Busch, G., (2016). Umsetzung des Themas Landwirtschaft im Schulunterricht. Eine quantitative Studie an Oberschulen und Gymnasien in Niedersachsen. German Association of Agricultural Economists (GEWISOLA), $56^{\text {th }}$ Annual Conference, Bonn, Germany, 28 $8^{\text {th }}-30^{\text {th }}$ September

Plaas, E., Schütte, R., (2016). The competitiveness of French wine producers with decreasing use of pesticides. Oral presentation at the $158^{\text {th }}$ EAAE Seminar, Chania, Greece, $8^{\text {th }}-9^{\text {th }}$ September

Schütte, R., Theuvsen, L., (2013). Lebensmittel im Electronic Commerce: Historische Entwicklung und aktuelle Trends. in: Massendatenmanagement in der Agrarund Ernährungswirtschaft Erhebung - Verarbeitung - Nutzung, Proceedings of 33. GIL-Jahrestagung 20. - 21. Februar 2013, Potsdam; ISBN 978-3-88579-605-3

\section{Presentations}

Schütte, R., Bergmann, H. (2017). Attitude of winegrowers towards cover crops in vineyards. Oral presentation at $11^{\text {th }}$ AAWE Conference, Padua, Italy, $28^{\text {th }}$ June$2^{\text {nd }}$ July

Plaas, E., Schütte, R. (2017). Effects of using cover crops in the inter-rows of vineyards. An ex-ante evaluation in France. Oral presentation at $91^{\text {st }}$ AES Conference, Dublin, Ireland, $24^{\text {th }}-26^{\text {th }}$ April

Bergmann, H., Plaas, E., Schütte, R. (2017). Competitiveness of wine across Europe Challenges and obstacles of economic analysis. Workshop Organisation, 91st AES Conference, Dublin, Ireland $24^{\text {th }}-26^{\text {th }}$ April

Schütte, R., Plaas, E., (2016). Economic Effects of an Herbicide Reduction in Viniculture - A model with the Policy Analysis Matrix. Oral presentation at the 10th AAWE Annual Conference. in Bordeaux, France, $21^{\text {st }}-25^{\text {th }}$ June

\section{Poster}

Schütte, R., Bergmann, H. (2017). Attitude of winegrowers towards cover crops in vineyards. Poster presentation, 91st AES Conference, Dublin, Ireland, 24 $4^{\text {th }}-26^{\text {th }}$ April 


\section{Declaration}

Name: Rebekka Schütte

Ich beabsichtige, eine Dissertation zum Thema "Supporting biodiversity in European vineyards: Possibilities for winegrowers and economic implications" an der GeorgAugust-Universität Göttingen anzufertigen. Dabei werde ich von Herrn Prof. Dr. Stephan von Cramon-Taubadel betreut.

Ich gebe folgende Erklärung ab:

1. Die Gelegenheit zum vorliegenden Promotionsvorhaben ist mir nicht kommerziell vermittelt worden. Insbesondere habe ich keine Organisation eingeschaltet, die gegen Entgelt Betreuerinnen und Betreuer für die Anfertigung von Dissertationen sucht oder die mir obliegenden Pflichten hinsichtlich der Prüfungsleistungen für mich ganz oder teilweise erledigt.

2. Hilfe Dritter wurde bis jetzt und wird auch künftig nur in wissenschaftlich vertretbarem und prüfungsrechtlich zulässigem Ausmaß in Anspruch genommen. Insbesondere sind alle Teile der Dissertation selbst angefertigt; fremde Hilfe habe ich dazu weder unentgeltlich noch entgeltlich entgegengenommen und werde dies auch zukünftig so halten.

Des Weiteren ist mir bekannt, dass Unwahrhaftigkeiten hinsichtlich der vorstehenden Erklärung die Zulassung zur Promotion ausschließen bzw. später zum Verfahrensabbruch oder zur Rücknahme des erlangten Grades berechtigen.

Göttingen, 8. Mai 2019

Rebekka Schütte 